NBER WORKING PAPER SERIES

\title{
ETHNIC DIFFERENCES IN DEMOGRAPHIC BEHAVIOR IN THE UNITED STATES: HAS THERE BEEN CONVERGENCE?
}

\author{
Michael R. Haines \\ Working Paper 9042 \\ http://www.nber.org/papers/w9042 \\ NATIONAL BUREAU OF ECONOMIC RESEARCH \\ 1050 Massachusetts Avenue \\ Cambridge, MA 02138 \\ July 2002
}

This essay was prepared for the "Workshop on the Historical Demography of Ethnicity: Population Processes and their Genetic Implications" at the California Institute of Technology, Pasadena, CA, May 13-14, 2002. Michael R. Haines is the Banfi Vintners Professor of Economics at Colgate University and Research Associate, National Bureau of Economic Research. The views expressed herein are those of the author and not necessarily those of the National Bureau of Economic Research.

(C) 2002 by Michael R. Haines. All rights reserved. Short sections of text, not to exceed two paragraphs, may be quoted without explicit permission provided that full credit, including $\mathbb{C}$ notice, is given to the source. 
Ethnic Differences in Demographic Behavior in the United States:

Has There Been Convergence?

Michael R. Haines

NBER Working Paper No. 9042

July 2002

JEL No. N3, J1

\begin{abstract}
This paper looks at the fertility, mortality, and marriage experience of racial, ethnic, and nativity groups in the United States from the 19th to the late 20th centuries. The first part consist of a description and critique of the racial and ethnic categories used in the federal census and in the published vital statistics. The second part looks at these three dimensions of demographic behavior. There has been both absolute and relative convergence of fertility across groups, It has been of relatively recent origin and has been due, in large part, to stable, or even slightly increasing, birth rates for the majority white population combined with declining birth rates for blacks and the Asian-origin, Hispanic-origin, and Amerindian populations. This has not been true for mortality. The black population has experienced absolute convergence but relative deterioration in mortality (neonatal and infant mortality, maternal mortality, expectation of life at birth, and age-adjusted death rates), in contrast to the Amerindian and Asian-origin populations. The Asian-origin population actually now has age-adjusted death rates significantly lower than those for the white population. The disadvantaged condition of the black population and the deteriorating social safety net are the likely origins of this outcome. Finally, there was a trend toward earlier and more extensive marriage from about 1900 up to the 1960s. At this point, coincident with the end of the "Baby Boom," there has been a movement to later marriage for both males and females among whites, blacks, and the Hispanic-origin populations. This trend has been more extreme in the black population, especially among females. There has also been a significant rise in proportions never-married at ages 45-54 among blacks and, to a lesser extent, among Hispanics. So here too, there has been some divergence.
\end{abstract}

Michael R. Haines

Department of Economics

Colgate University

13 Oak Drive

Hamilton, NY 13346

and NBER

Tel: $315-228-7536$

Fax: 315-228-7033

mhaines@mail.colgate.edu 
THE CONCEPTS OF RACE AND ETHNICITY IN THE UNITED STATES CENSUS AND VITAL STATISTICS

The fascination of Americans with race, ethnicity, and counting have always come together in the census. From the earliest census's division of the population into three groups to the 63 ethnic categories in Census 2000, the census has both reflected social realities and changes and affected our perceptions of them. ${ }^{1}$ This article summarizes the most recent estimates of trends in population, births, deaths, marriages, and divorces for most ethnic categories throughout American history. It is meant to serve as a reference about national ethnic trends from 1790 through 2000. Perhaps the most striking patterns show that, while ethnic group behavior has largely converged in fertility and marriage patterns, African-Americans continue to be markedly less healthy than whites or Asian-Americans.

The issue of measuring and analyzing racial and ethnic differences in population characteristics and vital processes has long been a feature of demography in the United states. The federal census has been collecting data on race since the first census of 1790, though that census merely divided the population into free whites, all other free persons, and slaves. The origin of this was in the Constitution itself which specified in Article I, Section 2 that the House of Representatives was to be apportioned "by adding to the whole Number of free Persons, including those bound to Service for a Term of Years, and excluding Indians not taxed, three fifths of all other persons." The "three fifths compromise" allowed slave states to count three fifths of their (disenfranchised and thus non-voting) slave populations for the purposes of Congressional representation. This distinction continued up to 1810, when the terms "colored persons" and "Indians not taxed" first appeared. In 1820, the free colored and slave populations were explicitly classified by age and sex. Since slaves were only persons of sub-Saharan African descent, no further racial distinction was used. Also, a category of "foreigners not naturalized" was given (and used again in 1830). This distinction continued up through 1850. In 1860, the categories of "Asiatics," "Civilized Indians," and "Half-Breeds" were added for some states. ${ }^{2}$ In

1 It should be strongly emphasized that the concept of race is a social one with no implication of a biological or genetic significance of component. For a detailed discussion of racial and ethnic classifications in the United States Census, see Lee [1993] for the 1890-1990 period, Edmonston and Schultze [1995, ch. 7] for the 1850 to 1990 period, and Anderson and Fienberg [1999, ch. 8] for the entire range of the federal census.

2 Asiatics (likely almost all Chinese) were tabulated only for California, while the ambiguous category of "Half-Breeds" was used only for Wisconsin and New Mexico. "Civilized Indians" were those Amerindian people living in regular domiciles in areas subject to enumeration. 
addition, in 1850, 1860, and 1870, the instruction was added to make a distinction between blacks and mulattos, though precisely how this was to be done was left

unclear. ${ }^{3}$ A listing of the racial categories used in the U.S. censuses from 1790 to 1990 is provided in Appendix Tables A-1 and A-2.

The question of nativity was not fully addressed until the census of 1850 , the first census to enumerate each individual (i.e., a nominal census). The previous six censuses had been enumerations by the name of head of household with summary categories of persons by age, sex, and race. As mentioned, the 1820 and 1830 censuses had questions about "foreigners not naturalized," but the 1850 census asked a question about each person's place of birth - state within the United States if native born and country of birth if foreign born. This has continued up to the present. In 1870 , questions were added about the nativity of the person's father and mother, although initially it was only native or foreign born. For the censuses of 1880 to 1970 , questions were asked about the detailed nativity of the father and mother (state within the United States, country if abroad), although these were only for samples for 1940-1970." With these questions, it was possible to tabulate the population by nativity. This was extensively done with a major distinction being made between the native white and the foreign-born white populations. Later categories were created for native white of native parentage and native white of foreign or mixed parentage. After 1970, however, the nativity of parents was no longer a question.

Some additional questions were added at various points in time that shed light on ethnicity. For example, a question on mother tongue as inserted in the censuses of 1910-1930 and again in 1960 and 1970 (for samples). Language spoken was also asked in 1910. This has been useful, for example, in analyzing some subgroups such as the Yiddish-speaking Jewish population) for which separate identification is otherwise difficult or impossible. [See, for example, Condran and Kramerow, 1991.] For immigrants, the number of years in the United States in 1900-1920 and again for 19701990. The ambiguous and difficult question on "ancestry" was first asked in 1980 and

3 For an account of instructions to enumerators up through the 2000 census, see U.S. Bureau of the Census [1979, 2002].

4 Sampling began in 1940 in which everyone was enumerated on the main form and then persons on the "sample lines" were asked supplementary questions. The same procedure was repeated in 1950. 25\% of persons were asked to answer additional questions in 1960 by the enumerator. In 1970, the first true self-enumerating census, a variety of different sample groups were asked to answer additional questions. In 1980, the practice of short and long forms began, with everyone enumerated at least on the short form. When enumerators were used, they were instructed to allow respondents to self identify race (which, or course, would occur with self enumeration). 
was repeated in 1990 and 2000. It is purely self identification and difficult to interpret.

The question of race has undergone a number of changes over time. At the 1870 census, slavery had legally ceased to exist in the United states, and the non-white population was then divided into "colored" (African American), "civilized Indians," Chinese, and Japanese. This taxonomy was continued in 1880, but in 1890 the black population was divided into blacks, mulattos, quadroons, and octoroons (see Appendix Table A-2). A simpler classification was restored in 1900, but the question on mulattos was asked again in 1910 and 1920 . Thereafter, the black population was identified as "Negro" or, from 1970, also as black. From 1910, the number of categories for other groups has proliferated, as Table A-1 shows. In 1930 , a decision was made to reclassify Mexicans as non-white, but that decision was reversed in the 1930s. Consequently, the 1940 census retabulated the population from 1930 with Mexicans placed among whites and published these results along with the 1940 tabulations. The 1990 census had 16 racial categories to choose from, including a residual category of "Other race."

The detailed tabulation of race, nativity, and ethnicity in the published volumes (for example by age and sex for geographic subunits) closely followed the official categories up to 1860, although detailed tabulations of the native- and foreign-born populations by age, sex, and race did not appear until 1870. Tabulations of the population by age, sex, race, and nativity at least for states then have been published up through the present, although the non-white population has sometimes been aggregated together (e.g., 1940-1960). For 1880, all non-white groups were placed together for the tables in a group called "colored." From 1870 to 1970 , there was a distinction of the native-born and foreign-born white population, though for $1950-1970$ it was generated from one of the samples. More recently (1980 and 1990), the distinction of nativity by race has been largely dropped. The current standard broad categories are: White; Black or African American; American Indian or Alaska Native; Asian; and Native Hawaiian or Pacific Islander. These categories were established by the Office of Management and Budget in 1977 in statistical Policy Directive 15 and modified in 1997. ${ }^{5}$ There are also two questions now on ethnicity: Hispanic or Latino, and Non-Hispanic or Non-Latino.

\footnotetext{
5 The categories from 1977 to 1997 were: White; Black; American Indian, Eskimo, or Aleut; and Asian or Pacific Islander. Census data for 1980 and 1990 and much recent vital statistics data are categorized this way.
} 
The identification of race is now self identification, which goes along with self enumeration (in effect since 1970). Some combination of self identification and enumerator identification was used in 1960. Before 1960 the judgement was left to the enumerator's observation. Persons of mixed white and another race were usually identified with the other race. Physical appearance was likely very important.

The separate enumeration and tabulation of the Hispanic population began in 1970, although the category "Mexican" had been given as an answer to the question on race or color in 1930. Before 1970, it is possible to identify a large portion of the Hispanic-origin population by looking at questions on place of birth, parent's place of birth, mother tongue or language, and (when available in the IPUMS samples) surname. These were used by Gratton and Gutmann [2000] to make their estimates of the size and composition of the Hispanic-origin population (see Table 2). Since 1970, specific questions have been asked about Spanish or Hispanic origin or descent. These are described in Appendix Table A-3. Unfortunately, Hispanic origin overlaps other racial categories, and so now there is a further division of the Hispanic and nonHispanic populations by the OMB categories (white, black, American Indian and Alaskan native, Asian, Hawaiian native or Pacific islander). A considerable amount of tabulation has been done in recent censuses for the Hispanic-origin population.

Citizenship status is a related inquiry. It was first asked in 1900 (citizen [assumed as blank], naturalized, applied for first papers, and alien) and has been included in the census since then with the exception of $1960 .{ }^{6}$ In 1980 , a confusing question on ancestry was introduced. It is wholly self identified and allows for multiple responses. The question certainly does not describe strict cultural or geographic categories and thus far seems to have had limited value for demographic and social science research.

The categories of race and ethnicity are still in a state of flux, having been changed as recently as 1997. They, and the politicized process of determining the categories, were seriously critiqued by William Petersen:

Indeed, the Census Bureau can do little or nothing to alter the political context of ethnic counts, nor can it escape from fiscal control by a Congress sensitive to racial and ethnic blocs. What it can do, for instance, is not to repeat the egregious error of inviting representatives of special interests to act as formal consultants supervising its operations. Instead of seeking to avoid pressure from ethnic blocs to revise definitions or enumeration procedures, the bureau invited the participation of blacks, Hispanics, Indians, and others, each of whom wanted to shape the process to its political advantage. These committees were of a type different from those made up of statisticians or typical users of census data, for the members were generally chosen less for

6 The citizenship question in 1970 was in the 5\% sample. 
their knowledge than for their ideology. Giving aspirant leaders this kind of quasi-official status aggravated the disadvantages of the procedure already established-the delineation of ethnic categories by self-identification combined with promotional campaigns that stressed the monetary advantages of larger counts, thus encouraging the creation of "instant" members of the various categories. [Petersen, 1987, p. 233.]

Presently, it is explicitly stated by the Census Bureau that the concept of race, whose categories are intended to be mutually exclusive, is not supposed to reflect any biological or anthropological definitions. That is laudable, but the fact remains that rather arbitrary changes over time have made secular comparisons more difficult. An example of the difficulty is the group of Hispanic origin population which is seen as an ethnic, and not a racial, group. Within the Hispanic origin population there are then racial groups. The change to self identification has further complicated matters. This is undoubtedly some improvement over enumerator identification, but further muddying the waters. For example, the Amerindian population of the United States grew by $5.4 \%$ per annum in the 1970s, 3.6\% per annum in the 1980s, and $7.4 \%$ per annum in the 1990s. ${ }^{7}$ Since this was a group for which net in-migration was likely negligible, such rapid growth would indicate significant amounts of self-redefinition. Finally, the category of "Other" now includes persons who identify with no racial category, often persons of mixed race. We do the best we can with what we have, but the limitations must be kept in mind.

The vital statistics of the United States suffer from many of the same issues. Systematic collection of vital statistics at the federal level only began with the creation of the Death Registration Area in 1900 (comprising at first only ten states and the District of Columbia) and the Birth Registration Area in 1915 (also initially comprising only ten states and the District of Columbia). Both were complete only in 1933 with the admission of Texas. A Marriage Registration Area was only set up in 1957, and a Divorce Registration Area was only created in 1958, although national estimates exist for the period since 1920. The Marriage and Divorce Registration Areas are still not complete. Birth and death data were reported by race (with a few exceptions), while marriages and divorces were often not. ${ }^{8}$ Through the 20 th century, much of the published reporting was done for whites and non-whites (often referred to

\footnotetext{
7 The term "Amerindian" is used here in preference to the term "Native American" because the latter is not properly descriptive of the origins of that group. The Canadian official statistics have used, for example, the terms "aboriginal" and "first inhabitants".

8 Consequently, much of the analysis of nuptiality relies on census-based measures, such as those presented in Table 8, below.
} 
as "All Others"). Separate reporting for blacks began in 1960 and for the Amerindian and Asian or Pacific Islander populations in 1980.

RACIAL AND ETHNIC DIFFERENCES IN DEMOGRAPHIC BEHAVIOR

Tables 1 and 2 provide information on the size, composition, and growth of the American population by race and ethnicity. An overview of fertility and mortality for the white and black population since 1800 is given in Table 3 . Fertility is described in detail in Tables 4 and 5, mortality in Tables 7 to 9, and nuptiality in Table 13. In addition, Tables 6, 10-12, and 14 exhibit comparisons of differentials of fertility, mortality, and marriage by race and ethnicity. POPULATION SIZE AND COMPOSITION

Table 1 provides information on the size and racial composition of the American population since 1790. The second panel has the percentage breakdown from 1790 to 2000 by race. Note that the category "Hispanic" is not part of the racial categorization and should be looked at separately.

At the beginning of the Republic, about four-fifths of the population was white and one-fifth black, most of whom were slaves in the South. In 1820, the first census to distinguish slaves from free blacks, the free black population was 13\% of the total black population. This proportion actually fell to about 11\% in 1860, largely due to the higher fertility of slaves relative to free blacks.. The share on the non-white population began to decline from the early 19th century to about 1930, when it stabilized for several decades. This decline was caused by the significant influx of migrants to the United States, most of whom were white Europeans. Between 1819 (the first date for which we have regular immigrant entry statistics) and 1920, approximately 34 million migrants entered the United States. This total was about 64 million through 1997. [U.S. Bureau of the Census, 1975, Series 89, and extensions by the author.]

From about 1950 the white share of total population began to decline such that it fell from about $90 \%$ to about $77 \%$ in the 2000 census. Although the share of the black population in the total has risen in recent decades, much of the increased share for non-whites has been in the category of "Other Races," especially Asians, who were about 45\% of that group, and the Amerindian population (about 15\% of "Other Races") . The Hispanic population is comprised of various races and is considered an ethnic and not a racial category (see Table 2). That population has grown at rates of $4 \%$ to $6 \%$ per year in the decades since 1940. A great deal of that growth more recently has 
been from persons of Mexican origin, who now comprise 58\% of the Hispanic origin population. The other important components are those of Puerto Rican origin and Cuban origin (9.6\% and 3.5\% of the Hispanic population, respectively), with a very rapidly growing group from other areas of Central and South America.

The implications for the demography of minorities is clear and well known. The United States if becoming less of nation of white persons of European origin and more a racially and ethnically diverse group. In recent years, the Asian and Hispanic populations have shown the most rapid growth (Table 1, last panel). The exceptionally fast growth of the Amerindian population is due to ethnic re-identification. Given the present immigration laws, policies, and practices in place and the attraction of the United States labor market, this trend shows every indication of continuing. FERTILITY

Evidence on fertility by race is presented in Tables 3 to 5 . The measures selected are the crude birth rate, the general fertility rate, the total fertility rate, and the census-based child-woman ratio. ${ }^{9}$ A notable feature of fertility in the early Republic was the large family size of white women, who exhibited a crude birth rate of about 55 in 1800 which implies a total fertility rate of about 7 live births per woman in her reproductive lifetime. Information for the black population does not become available until 1820 in the form of a child-woman ratio (children aged 0-4 per 1,000 women aged 20-44) and not until the 1850s for the crude birth rate and the total fertility rate. ${ }^{10}$ It is apparent that white fertility declined fairly steadily from 1800 until the onset of the "Baby Boom" in the 1940s, while black fertility remained rather stable up to the Civil War. This is not too surprising, since the incentives under slavery were for the profitable reproduction of the slave population. Nonetheless, after about 1880, the fertility of the black population began to decline in parallel with that for whites.

Table 6 shows that the total fertility rates for blacks and whites did not begin to converge until about 1880, when the black TFR was over 70\% higher than the white TFR. There was then a convergence up until about 1920, followed by some widening of

9 It is possible to reconstruct fertility and mortality rates back into the 19th century. Table 3 reports some of the results currently available. Improved estimates of the fertility of the white population back to 1850 will soon be available using own-children methods with the Integrated Public Use Micro Samples (IPUMS) of the censuses of 1850-1880, being conducted by J. David Hacker.

10 Note that the rates in Table 3 are for "All Other" (i.e., non-whites) for 1920-1970 for the crude birth rate and for 1940-1990 for the total fertility rate. But much of the non-white population (over 90\%) was black during those decades. 
the gap to about a 20-40\% higher TFR among black women (about one birth per woman). Since about 1990, however, the gap has begun to close to only a $6.4 \%$ higher TFR in 1998, amounting to only about.1 birth per woman. The decline since the end of the "Baby Boom" in the early 1960s has been significant, though much of it occurred in the 1990s. This may be seen graphically in Figure 1. Some of this has come from declines in birth rates among very young black women. For instance, birth rates for black women aged 15-17 declined from 82.3 per 1,000 in 1990 to 56.8 in 1998 (and from 152.9 to 126.8 for black women aged 18-19). [U.S. Bureau of the Census, 2000, Table 80]. But there has been some decline in age-specific rates at older ages as well. From 1980 onwards we have vital statistics for the Amerindian and the Asian populations, and from 1989 onwards for the Hispanic-origin population. In all these cases, convergence has been taking place. Indeed, for the Asian and Pacific Islander group, the TFR's are now below those for the white population, and those for the Hispanic-origin population are very close (Tables 5 and 6). For the Amerindian and Asian populations the convergence was taking place from the early 1980s. Table 5 provides some idea of the origins of all this. White TFR's stabilized in the $1970 \mathrm{~s}$ and began a slow increase to above 2 per woman (or 2,000 per 1,000 women) in the late 1990s. The increased representation of the somewhat higher fertility Hispanic women in the white population was certainly playing some role. Simultaneously, the TFR's for black, Amerindian, and Asian women declined a bit. Finally, the fertility of Hispanic-origin women remain roughly stable from 1989. What is occurring is that all groups seem to be converging on about 2 births per woman.

As to why minorities should have different fertility is an open question. If, as in the case of blacks, Hispanics, and the Amerindian population, a higher proportion have lower incomes, less wealth, less stable employment, and less education than the majority white population. These are factors often associated with higher birth rates. But there is also the "Minority Group Status Hypothesis," which conjectures that minority groups strive to improve their status. [Bean and Marcum, 1978.] This might be achieved using the help of more children, hence leading to higher birth rates. But there is the competing view that the desire to be upwardly mobile might spur more efforts toward family limitation to conserve family resources and concentrate on more human capital per child. Thus the predicted direction of the differential is unclear. The American case would seem to support the view that lower socioeconomic status has had the effect of raising fertility, but that these effects are diminishing over time, as birth rates come close to replacement levels. 


\section{MORTALITY}

Tables 7 through 9 provide measures of mortality for the racial and ethnic groups for which reporting was available over longer periods of time. Thus, the breakdown is for whites, all non-whites ("All Others"), and blacks. In the case of Hispanics, some data are available for infant mortality since 1989. The period covered is 1850 to 1998. Table 7 contains data on the neonatal mortality rate (deaths at 0-28 days of life per 1,000 live births), the infant mortality rate (deaths in the entire first year of life per 1,000 live births), and the maternal mortality rate (deaths from childbirth and its complications per 100,000 live births). Table 8 presents the expectation of life at birth by sex and for both sexes combined. Table 9 provides data on age-adjusted death rates by race and sex from 1900 to 1998. The data in Table 7 for 1915 to 1932 are for the current Birth Registration Area only. Similarly, the data in Tables 8 (lower panel) and 9 for 1900 to 1932 are for are also for the Death Registration Area. The relationships to the white population are given in Table 10 for the neonatal mortality rate, the infant mortality rate, and the maternal mortality rate, Table 11 for the expectation of life at birth, and Table 12 for age-adjusted death rates.

The picture for mortality is different from that for fertility. It is not one of relative convergence. If anything, there has been substantial relative divergence, although there has been much closing of the white/non-white gap in terms of absolute numbers of deaths per number of live births of in years of expectation of life. The difference in the number of infant deaths per 1,000 live births between whites and blacks has been reduced from 41 in 1900 and 46 in 1910 to 8.3 in 1998 . The reduction has been even greater for all non-whites (to 2.6 infant deaths in 1998). But the relative situation has deteriorated. Black infant mortality was in a more favorable circumstance relative to white infant mortality in 1900 (42\% higher) than at any subsequent date. In 1998 it was 137\% higher. The more favorable showing of entire group of non-whites reflects undoubtedly the more favorable showing of the Asian and Pacific Islander population. A graphic depiction of this relative divergence is presented in Table 10 and Figure 2 .

The serious disadvantage of the nonwhite population is traceable significantly to their low average levels of education and income. This is true especially for blacks but also for the Amerindian population. It also holds for the Hispanic population (both white and nonwhite). The Asian/Pacific Islander population as a whole does not suffer from this mortality penalty. On two counts, American society has come up short 
- it has failed to provide adequate health and medical care to its poor, and it has also failed to raise the level of living of many of its poor. In 1996, the United States ranked $29^{\text {th }}$ in the world in infant mortality. But even if all Americans has the same infant mortality rate as the white population (6.1), the United States would still only be tied for $21^{\text {st }}$ place [World Bank, 1998]. A wealthy and technologically advanced society surely can and should do more. As Antonovsky and Bernstein [1977, p. 459] note: "Low social class per se does not cause high infant mortality...however,...social class does subsume a large set of more directly causative biological and behavioral variables." Some of those causative variables may be amenable to direct policy intervention (e.g., universal child immunization programs), but some may be address by more general improvements in the living standards of the society, particularly among its poor.

The record for neonatal mortality was about the same as for overall infant mortality. Similarly, maternal mortality showed deterioration from the early 20 th century up to the early $1960 \mathrm{~s}$ and then a modest improvement. But maternal mortality is still over three times higher for the black population than the white population, despite a reduction in the absolute number of maternal deaths per 100,000 live births from 455 in 1915 (for all non-whites) to 12 for blacks and 9.8 for all non-whites in 1998. The relative difference seems to have no trend at present.

Table 8 demonstrates that overall black and non-white mortality, as measured by the expectation of life at birth, was higher throughout the period 1900 to 1998 . Table 11 gives the relative deficit of the total non-white and black expectations of life at birth annually since 1900. Up to 1933, those estimates are for the current Death Registration Area. The upper panel of Tables 8 and 11 contain estimates for 1900 and 1910 for the whole nation based on indirect estimation from the samples of the microdata from the 1900 and 1910 U.S. censuses. [Haines, 1998; Preston and Haines, 1991; Haines and Preston, 1997.] Since those are estimates for the whole population, rather than the rather restricted sample of the early Death Registration Area, those estimates are to be preferred to the annual estimates in the lower panel. If those benchmarks are used, the picture for the black population is somewhat more favorable, since in 1900 and 1910 the national black population was more rural than in the Death Registration Area, which afforded some degree of protection. The DRA of 1900 had less than 5\% of the nation's African American population, and, of that, 82-83\% was urban. The national average percentage urban of the black population was $20 \%$ in 1900 and $27 \%$ in 1910. [Haines and Preston, 1997.] Although by those standards, real progress has 
been made, nonetheless, in 1998, black males still had e(0) 6.9 years below those for white males. The number for black females was a deficit of 5.2 years. These numbers in 1900 had only been 8.1 and 7.4 years, respectively.

Table 9 provides data on age-adjusted death rates by race and sex from 1900 to 1998. These are also for the Death registration Area up through 1932. Table 12 gives the ratios of these age-adjusted death rates to those for the majority white population. The record there would indicate only modest progress for the African American population (the overwhelming share of the "All Other" category until the 1950s). In 1998, the age-adjusted death rate for blacks stood 53\% higher than for whites. Interestingly, for the Amerindian and Asian populations, the outcomes are better. Indeed, the younger populations of those groups do relatively well, with Amerindians close to the white rates and the Asian and Pacific Islander origin population substantially below the white population (58\% of the white rates). Overall, however, the record on minority mortality is less than admirable.

The source of this is to be found in disadvantaged socioeconomic status not ameliorated by corrective social policies. No extensive national-level information on income for individuals exists before 1939. The first census to ask a question on income was the U.S. Census of Population of 1940, and for that census the question was only about wage and salary income for 1939, excluding proprietary, self-employment, and property income. Much of what we know about American incomes by race originates in the Current Population Survey, conducted monthly by the Bureau of the Census since 1947, particularly aimed at labor force issues such as unemployment and income. ${ }^{11}$ One partial earlier piece of evidence may be gleaned from a Bureau of Labor Statistics survey taken in 1917-1919 of 12,817 families in 99 urban centers in 42 states of the United States for purposes of studying the cost of living [United States Bureau of Labor Statistics, 1924]. In that study, white family heads had average earnings of $\$ 1,352$ while colored family heads had average earnings of $\$ 979$ (or $72 \%$ of that of

11 Originally in 1947, the Survey covered a representative sample of approximately 21,000 interviewed households in areas throughout the United States. This sample was increased to approximately 35,000 in May 1956 and to approximately 50,000 in January 1967. It is subject to sampling error. At present, about 50,000 occupied households are eligible for interview each month. Of these, about 4 to 5 percent are, for a variety of reasons, unavailable for the interview. Estimates of population characteristics based on the CPS will not agree with counts based on the census because the CPS and the census use different sampling procedures, different samples, and different procedures for racial groups, the Hispanic population, and other topics. 
whites). ${ }^{12}$ For the period 1947 to 1970, families headed by non-whites had median incomes of 51-64\% of those for whites heading families. The range was 61-78\% for unrelated individuals. In the case of families, there appeared to have been an improvement over time in both real income (in constant 1967 dollars) and in relation to income for white-headed families. This was not, however, true for unrelated individuals, who did experience a rise in real income but showed no trend relative to whites. [U.S. Bureau of the Census, 1975, Series G 189-204.] By 1998, the median income of black-head households was $62 \%$ of that of white households (in contrast to 113\% for Asian-headed households and 69\% for Hispanic-headed households). [U.S. Bureau of the Census, 2000, Table 737.] In terms of income distribution, the Current Population survey also reveals that in 1947 46\% of families with white head had income below $\$ 3,000$, while this was $81 \%$ for families with a non-white head. This had improved to $7.5 \%$ for whites and $20.1 \%$ for non-whites by 1970 , both because of rising real and nominal incomes; but the gap was still substantial. Similar results obtain for unrelated individuals. In $1947,61 \%$ of whites had incomes under $\$ 1,500$, while $79 \%$ of non-whites were in that situation. By 1970, this was 21\% for whites but still 35\% for non-whites. [U.S. Bureau of the Census, 1975, Series G 16-30.] In 1998, 8.7\% of white-headed households had incomes below $\$ 10,000$, while this was $21.4 \%$ for blackheaded households and 14.9\% for Hispanic-headed households. [U.S. Bureau of the Census, 2000, Table 738.]

Overall, the disadvantaged status of non-whites generally, and blacks in particular, are demonstrated by these income disparities, Since socioeconomic wellbeing has an important effect on expectation of life, infant mortality, and death rates overall, it is not surprising that the relative disadvantage of the black population in mortality has not disappeared. NUPTIALITY

Finally, some results on nuptiality are presented in Table 13 with ratios for the non-white, black, and Hispanic-origin populations to the white population in Table 14 . Over the period 1880 to 1990 covered by those tables, there have been fluctuations in the age at marriage (given by the singulate mean age at marriage) and the percent married at ages 20-24. There have been comparable fluctuations in the proportion never-married at ages 45-54 and in Coale's indices of proportions married (Im and Im*). There was a rise in the age of marriage to about 1900 (probably throughout the 
19th century), followed by a decline up to the 1960s, and then a rather dramatic increase. Among whites, the recent rising age of marriage was not accompanied by an increase in lifetime non-marriage (proportion single at ages 45-54); but there was a sharp rise in this among blacks. Most notably, the non-white population and the black population in particular have moved from having had a first marriage age substantially below that for whites to an age well above it. This dramatic reversal may be seen in Table 14 and in Figure 3. The black/white differential was even more pronounced for females than for males. This was not true of the Hispanic-origin population, which seemed to move more closely with the white population. The overall rise in the age at marriage and in the proportions never-marrying reflects a tendency toward delayed marriage and childbearing among working women and also a trend towards a greater proportion of female-headed households among all households. In 1990, 12.9\% of all families were headed by women with no spouse present in the white population, in contrast to $43.8 \%$ in the black population. The percentages for female-headed families with no spouse present and with own children were $7.4 \%$ for whites and 29.9\% for blacks. [U.S. Bureau of the Census, 1997, Table 50.] These proportions have been on the rise since the middle of the 20 th century.

\section{CONCLUDING COMMENTS}

Examining data from a variety of statistical sources on the demography of racial and ethnic groups in the United States to the present reveals some interesting results. Taking into account the changing definitions and boundaries of race and ethnicity in official federal statistics, the has been both relative and absolute convergence in fertility behavior across groups. It has been of relatively recent origin and has been due, in large part, to stable (or even slightly increasing) birth rates for the majority white population combined with declining birth rates for blacks and the Asian-origin, Hispanic-origin, and Amerindian populations.

This has not been true for mortality, however. The black population has experienced absolute convergence but relative deterioration in mortality (neonatal and infant mortality, maternal mortality, expectation of life at birth, and age-adjusted death rates), in contrast to the Amerindian and Asian-origin populations. The Asianorigin population actually now has age-adjusted death rates significantly lower than those for the white population. ${ }^{13}$ The disadvantaged condition of the black population

13 The age-adjusted death rates for the Hispanic-origin population are available only since 1994. For the 1994-98 period, those rates were lower than those for the white population (at about 80\%). 
and the deteriorating social safety net are the likely origins of this outcome.

Finally, there was a trend toward earlier and more extensive marriage from about 1900 up to the 1960s. At this point, coincident with the end of the "Baby Boom," there has been a movement to later marriage for both males and females among whites, blacks, and the Hispanic-origin populations. This trend has been more extreme in the black population, especially among females. There has also been a significant rise in proportions never-married at ages 45-54 among blacks and, to a lesser extent, among Hispanics. So here too, there has been divergence.

The lessons to be learned are not that the American population is becoming more homogeneous. On the contrary, it is seemingly more heterogeneous. But it seems that groups are responding in similar ways to social trends and constraints. The most troubling result is the relative deterioration of the mortality situation for the black population. This is clearly an issue which warrants the most serious attention by policy makers. 


\section{REFERENCES}

Anderson, Margo J., and Stephen E. Fienberg. 1999. Who Counts? The Politics of CensusTaking in Contemporary America. New York: Russell Sage Foundation.

Antonovsky, Aaron, and Judith Bernstein.1977. "Social Class and Infant Mortality." Social Science and Medicine. Vol.11, No.8/9 (May). pp. 453-477.

Bean, Frank D., and John P. Marcum. 1978. "Differential Fertility and the Minority Group Status Hypothesis: An Assessment and Review" In Frank D. Bean and W. Parker Frisbee, eds. The Demography of Racial and Ethnic Groups. New York: Academic Press. pp. 189-211.

Bean, Frank D., and John P. Marcum. 1978. "Differential Fertility and the Minority Group Status Hypothesis: An Assessment and Review." In Frank D. Bean and W. Parker Frisbee, eds. 1978. The Demography of Racial and Ethnic Groups. New York: Academic Press. pp. 189-211.

Coale, Ansley J., and Susan Cotts Watkins, eds. 1986. The Decline of Fertility in Europe. Princeton, NJ: Princeton University Press.

Coale, Ansley J., and Norfleet W. Rives, Jr. 1973. "A Statistical Reconstruction of the Black Population of the United States, 1880-1970. Estimates of True Numbers by Age and Sex, Birth Rates and Total Fertility." Population Index. Vol. 39, No. 1

(January) . pp. 3-36.

Coale, Ansley J., and Melvin Zelnik. 1963. New Estimates of Fertility and Population in the United States. A Study of Annual White Births from 1855 to 1960 and of Completeness of Enumeration in the Censuses from 1880 to 1960. Princeton, NJ: Princeton University Press.

Condran, Gretchen A., and Eileen A. Kramerow. 1991. "Child Mortality among Jewish Immigrants to the United States." Journal of Interdisciplinary History. Vol. 22, No.2. pp. 223-254.

Edmonston, Barry, and Charles Schultze, eds. 1995. Modernizing the U.S. Census. Washington, DC: National Academy Press.

Gratton, Brian, and Myron P. Gutmann. 2000. "Hispanics in the United States, 18501990: Estimates of Population Size and National Origin." Historical Methods. Vol. 33, No. 3 (Summer). pp. 137-153.

Haines, Michael R. 1989. "American Fertility in Transition: New Estimates of Birth Rates in the United States, 1900-1910." Demography. Vol. 26, No. 1 (February). pp. $137-148$.

Haines, Michael R. 1998. "Estimated Life Tables for the United States, 1850-1910." Historical Methods. Vol. 31, No. 4 (Fall). pp. 149-169.

Haines, Michael R., and Samuel H. Preston. 1997. "The Use of the Census to Estimate Childhood Mortality: Comparisons from the 1900 and 1910 United States Census Public Use Samples." Historical Methods. Vol. 30, No. 2 (Spring). pp. 77-97.

Haines, Michael R., and Richard H. Steckel, eds. 2000. A Population History of North America. New York: Cambridge University Press.

Hajnal, John. 1953. "Age at Marriage and Proportions Marrying." Population Studies. Vol. 7, No. 3 (November). pp. 111-136.

Kiser, Clyde V., Wilson H. Grabill, and Arthur A. Campbell. 1968. Trends and Variations in Fertility in the United States. Cambridge, MA: Harvard University Press.

Lee, Sharon M. 1993. "Racial Classifications in the U.S. Census: 1890-1990." Ethnic and Racial Studies. Vol. 16, No. 1 (January). pp. 75-94.

Linder, Forrest E., and Robert D. Grove. 1947. Vital Statistics Rates in the United States, 1900-1940. Washington, DC: U.S. Government Printing Office.

Petersen, William. 1987. "Politics and the Measurement of Ethnicity." In William Alonso and Paul Starr, eds. The Politics of Numbers. New York: Russell Sage 
Foundation. pp. 187-233.

Preston, Samuel H., and Michael R. Haines. 1991. Fatal Years: Child Mortality in Late Nineteenth Century America. Princeton, NJ: Princeton University Press.

Price, Daniel 0. 1969. Changing Characteristics of the Negro Population. Washington, DC: U.S. Government Printing Office.

Sheldon, Henry D. 1955. The Older Population of the United States NY: John Wiley and Sons.

Steckel, Richard H. 1986. "A Dreadful Childhood: Excess Mortality of American Slaves." Social Science History. Vol. 10, No. 4 (Winter). pp. 427-465.

Taeuber, Conrad, and Irene B. Taeuber. 1958. The Changing Population of the United States. New York: John Wiley and sones.

Taeuber, Conrad, and Irene B. Taeuber. 1971. People of the United States in the 20 th Century. Washington, DC: U.S. Government Printing Office.

Thompson, Warren S., and P. K. Whelpton. 1933. Population Trends in the United States. NY: McGraw-Hill.

U.S. Bureau of the Census. 1975. Historical Statistics of the United States. Colonial Times to 1970. Washington, DC: U.S. Government Printing Office.

U.S. Bureau of the Census. 1979. Twenty Censuses. Population and Housing Questions, 1790-1980. Washington, DC: U.S. Government Printing Office.

U.S. Bureau of the Census. 1983. 1980 Census of Population. Vol. 1, "Characteristics of the Population." Chapter B. "General Population Characteristics." Part 1, "United States Summary." (PC80-1-B1). Washington, D.C.. Government Printing Office.

U.S. Bureau of the Census. 1984. 1980 Census of Population. "Detailed Population Characteristics: United States Summary," (PC80-1-D1-A). Washington, D.C.. Government Printing Office.

U.S. Bureau of the Census. 1986. Statistical Abstract of the United States, 1986. Washington, D.C.. Government Printing Office.

U.S. Bureau of the Census. 1992. 1990 Census of Population. "General Population Characteristics," "United States," (1990 CP-1-1). Washington, D.C.. Government Printing Office.

U.S. Bureau of the Census. 1993a. 1990 Census of Population and Housing: History. Part A, (1990 CPH-R2A). Washington, D.C.. Government Printing Office.

U.S. Bureau of the Census. 1993b. 1990 Census of Population. "Social and Economic Characteristics, United States." (1990-CP-2-1). Washington, D.C.: Bureau of the Census.

U.S. Bureau of the Census. 1997. Statistical Abstract of the United States, 1997. Washington, D.C.. Government Printing Office.

U.S. Bureau of the Census. 2000. Statistical Abstract of the United States, 2000. Washington, D.C.. Government Printing Office.

U.S. Bureau of the Census. 2002. DP-1. Profile of General Demographic Characteristics: 2000. Census 2000, Summary File (SF 1). 100 Percent Data (from http://factfinder.census.gov/home/en/datanotes/expsflu.htm).

U.S. Bureau of the Census. 2002. Measuring America: The Decennial Censuses from 1790 to 2000. POL/02-MA. Washington, D.C.: U.S. Bureau of the Census. (April).

U.S. Bureau of Labor Statistics. 1924. "Cost of Living in the United States, 1917-19." Bulletin No. 357. Wash., D.C.: Government Printing Office, 1924.

U.S. Public Health Service. National Center for Health Statistics. 1970. Vital Statistics of the United States, 1968. Vol. I. "Natality." Washington, D.C.: Public Health Service.

U.S. Public Health Service, National Center for Health Statistics. 1996. Vital 
Statistics of the United States, 1992. Vol. II, "Mortality," Part A. Washington, D.C.: Public Health Service.

U.S. Public Health Service. National Center for Health Statistics. 1997. Vital Statistics of the United States, 1993, preprint of vol. II, "Mortality", part A, section 6, "Life Tables." Hyattsville, MD: Public Health Service.

U.S. Public Health Service. National Center for Health Statistics. 1999a. Vital Statistics of the United States, 1993. Vol. I. "Natality." Washington, D.C.: Public Health Service.

U.S. Public Health Service. National Center for Health Statistics. 1999b. National Vital Statistics Report, Vol. 47, No. 19, "Deaths: Final Data for 1997." (June).

U.S. Public Health Service. National Center for Health Statistics. 2000a. National Vital Statistics Report. Vol. 48, No. 3. "Births: Final Data for 1998." (March).

U.S. Public Health Service. National Center for Health Statistics. 2000b. National Vital Statistics Report, Vol. 48, No. 11, "Deaths: Final Data for 1998." (November). The World Bank. 1998. World Development Indicators 1998. CD-ROM. Washington, DC: The World Bank.

Wright, Carroll D., and William C. Hunt. 1900. History and Growth of the United States Census. Washington, D.C.. Government Printing Office. 
Table 1. Population by Race \& Ethnicity. United States, 1790 to 2000.

\begin{tabular}{|c|c|c|c|c|c|c|c|c|c|c|c|c|}
\hline Year & & All Races & White & Black & $\begin{array}{c}\text { Other } \\
\text { Races } \\
\text { /1 }\end{array}$ & Amerindian & $\begin{array}{c}\text { Asian or } \\
\text { Pac. Is }\end{array}$ & Japanese & Chinese & Filipino & Other & Hispanic \\
\hline 1790 & & 3929625 & 3172444 & 757181 & ------- & -------- & -------- & ------- & -------- & ------ & --- & $\begin{array}{l}----- \\
-----\end{array}$ \\
\hline $\begin{array}{l}18 \\
18\end{array}$ & & $\begin{array}{l}5308483 \\
7239881\end{array}$ & $\begin{array}{l}4306446 \\
5862073\end{array}$ & $\begin{array}{l}1002037 \\
1377808\end{array}$ & $\begin{array}{l}------- \\
------\end{array}$ & $\begin{array}{l}----- \\
----\end{array}$ & $\begin{array}{l}---- \\
----\end{array}$ & $\begin{array}{l}--1 \\
--\end{array}$ & $\begin{array}{l}----- \\
-----\end{array}$ & $\begin{array}{l}--- \\
--1\end{array}$ & $\begin{array}{l}------- \\
-------\end{array}$ & $\begin{array}{l}----- \\
-----\end{array}$ \\
\hline $\begin{array}{l}1810 \\
1820\end{array}$ & & $\begin{array}{l}7239881 \\
9638453\end{array}$ & $\begin{array}{l}5862073 \\
7866797\end{array}$ & $\begin{array}{l}1377808 \\
1771656\end{array}$ & $\begin{array}{l}------- \\
-------\end{array}$ & ---- & --- & ------ & ------ & ------ & -------- & ----- \\
\hline 183 & & 12866020 & 1053 & 23 & ------- & ------- & ------- & ------- & ------- & ------ & ------- & ----- \\
\hline 184 & & 17069453 & 5805 & 28 & ------- & ------- & ------- & ------- & ------- & ------- & ------- & ----- \\
\hline 18 & & 9187 & 3068 & 36 & ------ & ------- & ------- & ------- & ------- & ------- & ------- & 116943 \\
\hline 18 & & 314 & 269 & 44 & 78954 & 44021 & ------- & ------- & 34933 & ------ & ------- & ----- \\
\hline 18 & $\backslash 2$ & 385 & 377 & 48 & 88985 & 31 & ------- & 55 & 6319 & ------- & ------- & ----- \\
\hline 18 & & & 70 & 65 & 172020 & 407 & ------ & $14 \varepsilon$ & & ------ & ------- & 393555 \\
\hline 18 & & 62 & 55 & 74 & 357 & 53 & ------ & 203 & 1 & ------- & ------- & ----- \\
\hline 190 & & 759 & 668 & 88 & 351 & 96 & ------- & 24326 & 8 & ------- & ------- & 503189 \\
\hline 19 & & 66 & 57 & 98 & 412546 & 683 & ------- & 72157 & 7 & 160 & 3015 & 94 \\
\hline 1 & & $105^{\circ}$ & 15 & 104 & 426 & 37 & ------- & 11 & & & 85 & 1286154 \\
\hline 19 & 13 & 1227 & 1102 & 11 & 597 & 397 & ------- & 138834 & 7 & $4520 \varepsilon$ & 5770 & ----- \\
\hline 1940 & & 131669275 & 1182 & 1286 & 588887 & 333969 & ------- & 126947 & 77 & 45563 & 4904 & 1820 \\
\hline 1950 & & 150697361 & $134 \mathrm{~s}$ & 150 & 713047 & 410 & ------ & 141768 & & 616 & 8604 & 409 \\
\hline & $\backslash 4$ & 179323175 & 158 & & 9612 & & ------- & 464332 & & 176310 & 87 & 784 \\
\hline 1 & $\backslash 5$ & 203211926 & 17774 & 2258 & 2882662 & 30 & & 290 & 43 & 060 & 520 & 940 \\
\hline 10 & & 226 & 1622 & 26495025 & 11679158 & 1364033 & 35 & 700974 & 040 & 774652 & 459 & 1460 \\
\hline & 16 & 9873 & 070 & & 7743 & 234 & 3662 & ------ & ------ & 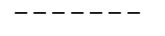 & 34 & \\
\hline & & & & 9434 & 7 & 01 & 3242 & 5700 & 43 & & 7949 & 35505 \\
\hline
\end{tabular}


Table 1 (cont.)

\begin{tabular}{|c|c|c|c|c|c|c|c|c|c|c|c|}
\hline Year & All Races & White & Black & $\begin{array}{l}\text { Other } \\
\text { Races }\end{array}$ & Amerindian & $\begin{array}{cl}\text { Asian or } \\
\text { Pac. Isl }\end{array}$ & $\begin{array}{l}\text { Japanese } \\
\text { - }\end{array}$ & Chinese & Filipino & Other & Hispanic \\
\hline PERCENT & $\begin{array}{l}\text { SHARES } \\
100.0 \%\end{array}$ & $80.7 \%$ & $19.3 \%$ & --- & ---- & ---- & ---- & ---- & ---- & ---- & --- \\
\hline 1800 & $100.0 \%$ & $81.1 \%$ & $18.9 \%$ & --- & ---- & ---- & ---- & ---- & ---- & ---- & ---- \\
\hline 1810 & $100.0 \%$ & $81.0 \%$ & $19.0 \%$ & --- & ---- & ---- & ---- & ---- & ---- & ---- & ---1 \\
\hline 1820 & $100.0 \%$ & $81.6 \%$ & $18.4 \%$ & --- & ---- & ---- & ---- & ---- & ---- & ---- & ---- \\
\hline 1830 & $100.0 \%$ & $81.9 \%$ & $18.1 \%$ & --- & ---- & ---- & ---- & ---- & ---- & ---- & ---- \\
\hline 1840 & $100.0 \%$ & $83.2 \%$ & $16.8 \%$ & --- & ---- & ---- & ---- & ---- & ---- & ---1 & ---- \\
\hline 1850 & $100.0 \%$ & $84.3 \%$ & $15.7 \%$ & --- & ---- & ---- & ---- & ---- & ---- & ---- & $0.5 \%$ \\
\hline 1860 & $100.0 \%$ & $85.6 \%$ & $14.1 \%$ & 0.3 & $0.1 \%$ & ---- & ---- & $0.1 \%$ & ---- & ---- & ---- \\
\hline 1870 & $100.0 \%$ & $87.1 \%$ & $12.7 \%$ & 0.2 & $0.1 \%$ & ---- & $0.0 \%$ & $0.2 \%$ & ---- & ---- & ---- \\
\hline 1880 & $100.0 \%$ & $86.5 \%$ & $13.1 \%$ & 0.3 & $0.1 \%$ & ---- & $0.0 \%$ & $0.2 \%$ & ---- & ---- & $0.8 \%$ \\
\hline 1890 & $100.0 \%$ & $87.5 \%$ & $11.9 \%$ & 0.6 & $0.4 \%$ & ---- & $0.0 \%$ & $0.2 \%$ & ---- & ---- & ---- \\
\hline 1900 & $100.0 \%$ & $87.9 \%$ & $11.6 \%$ & 0.5 & $0.3 \%$ & ---- & $0.0 \%$ & $0.1 \%$ & ---- & ---- & $0.7 \%$ \\
\hline 1910 & $100.0 \%$ & $88.9 \%$ & $10.7 \%$ & 0.4 & $0.3 \%$ & ---- & $0.1 \%$ & $0.1 \%$ & $0.0 \%$ & $0.0 \%$ & $0.9 \%$ \\
\hline 1920 & $100.0 \%$ & $89.7 \%$ & $9.9 \%$ & 0.4 & $0.2 \%$ & ---- & $0.1 \%$ & $0.1 \%$ & $0.0 \%$ & $0.0 \%$ & $1.2 \%$ \\
\hline 1930 & $100.0 \%$ & $89.8 \%$ & $9.7 \%$ & 0.5 & $0.3 \%$ & ---- & $0.1 \%$ & $0.1 \%$ & $0.0 \%$ & $0.0 \%$ & ---- \\
\hline 1940 & $100.0 \%$ & $89.8 \%$ & $9.8 \%$ & $0.4=$ & $0.3 \%$ & ---- & $0.1 \%$ & $0.1 \%$ & $0.0 \%$ & $0.0 \%$ & $1.5 \%$ \\
\hline 1950 & $100.0 \%$ & $89.5 \%$ & $10.0 \%$ & 0.5 & $0.2 \%$ & ---- & $0.1 \%$ & $0.1 \%$ & $0.0 \%$ & $0.0 \%$ & $2.1 \%$ \\
\hline 1960 & $100.0 \%$ & $88.6 \%$ & $10.5 \%$ & 0.9 & $0.3 \%$ & ---- & $0.3 \%$ & $0.1 \%$ & $0.1 \%$ & $0.1 \%$ & $3.2 \%$ \\
\hline 1970 & $100.0 \%$ & $87.5 \%$ & $11.1 \%$ & 1.4 & $0.4 \%$ & ---- & $0.3 \%$ & $0.2 \%$ & $0.2 \%$ & $0.4 \%$ & $4.4 \%$ \\
\hline 1980 & $100.0 \%$ & $83.1 \%$ & $11.7 \%$ & 5.2 & $0.6 \%$ & $1.5 \%$ & $0.3 \%$ & $0.4 \%$ & $0.3 \%$ & $3.5 \%$ & $6.4 \%$ \\
\hline 1990 & $100.0 \%$ & $80.3 \%$ & $12.1 \%$ & 7.7 & $0.8 \%$ & $2.9 \%$ & ---- & ---- & ---- & $3.9 \%$ & $9.0 \%$ \\
\hline 2000 & $100.0 \%$ & $77.1 \%$ & $12.9 \%$ & 10.0 & $1.5 \%$ & $4.5 \%$ & $0.3 \%$ & $0.9 \%$ & ---- & $2.8 \%$ & $12.6 \%$ \\
\hline
\end{tabular}


Table 1 (cont.)

\begin{tabular}{|c|c|c|c|c|c|c|c|c|c|c|c|c|}
\hline Year & All & Races & White & Black & $\begin{array}{l}\text { Other } \\
\text { Races }\end{array}$ & Amerindian & $\begin{array}{c}\text { Asian or } \\
\text { Pac. Isl }\end{array}$ & $\begin{array}{l}\text { Japanese } \\
\text {. }\end{array}$ & Chinese & Filipino & Other & Hispanic \\
\hline GROWTH & RATE & SINCE & PREVIOUS & CENSUS & & & & & & & & \\
\hline 1800 & & $3.01 \%$ & $3.06 \%$ & $2.80 \%$ & ----- & ----- & ----- & ----- & ----- & ----- & ----- & ----- \\
\hline 1810 & & $3.10 \%$ & $3.08 \%$ & $3.18 \%$ & ----1 & ----- & ----- & ----- & ----- & ----- & ----- & ----- \\
\hline 1820 & & $2.86 \%$ & $2.94 \%$ & $2.51 \%$ & ----- & ----- & ----- & ----- & ----- & ----- & ----- & ----- \\
\hline 1830 & & $2.89 \%$ & $2.92 \%$ & $2.73 \%$ & ----- & ----- & ----- & ----- & ----- & ----- & ----- & ----- \\
\hline 1840 & & $2.83 \%$ & $2.98 \%$ & $2.10 \%$ & ----1 & ----- & ----- & ----- & ----- & ----- & ----- & ----- \\
\hline 1850 & & $3.07 \%$ & $3.20 \%$ & $2.36 \%$ & ----- & ----- & ----- & ----- & ----- & ----- & ----- & ----- \\
\hline 1860 & & $3.04 \%$ & $3.20 \%$ & $1.99 \%$ & ----- & ----- & ----- & ----- & ----- & ----- & ----- & ----- \\
\hline 1870 & & $2.04 \%$ & $2.21 \%$ & $0.94 \%$ & $1.20 \%$ & $-5.37 \%$ & ----- & ----- & $5.93 \%$ & ----- & ----- & ----- \\
\hline 1880 & & $2.63 \%$ & $2.56 \%$ & $2.99 \%$ & $6.59 \circ$ & $9.48 \%$ & ----- & ----- & $5.12 \%$ & ----- & ----- & $4.05 \%$ \\
\hline 1890 & & $2.27 \div$ & $2.39 \%$ & $1.29 \%$ & $7.32 \%$ & $13.19 \%$ & ----- & ----- & $0.19 \%$ & ----- & ----- & ----- \\
\hline 1900 & & $1.88 \%$ & $1.93 \%$ & $1.65 \%$ & $-0.18 \%$ & $-0.46 \%$ & ----- & $24.79 \%$ & $-1.79 \%$ & ----- & ----- & $1.23 \%$ \\
\hline 1910 & & $1.91 \%$ & $2.02 \%$ & $1.07 \%$ & $1.60 \%$ & $1.13 \%$ & ----- & $10.87 \%$ & $-2.28 \%$ & ----- & ----- & $4.61 \%$ \\
\hline 1920 & & $1.39 \%$ & $1.49 \%$ & $0.63 \%$ & $0.33 \%$ & $-0.83 \%$ & ----- & $4.31 \%$ & $-1.49 \%$ & $35.56 \%$ & $2.54 \%$ & $4.77 \%$ \\
\hline 1930 & & $1.50 \%$ & $1.51 \%$ & $1.28 \%$ & $3.36 \%$ & $3.07 \%$ & ----- & $2.24 \%$ & $1.96 \%$ & $20.88 \%$ & $3.96 \%$ & ----- \\
\hline 1940 & & $0.70 \%$ & $0.69 \%$ & $0.79 \%$ & $-0.14 \frac{\circ}{9}$ & $0.05 \%$ & ----- & $-0.90 \%$ & $0.33 \%$ & $0.08 \%$ & $-1.63 \%$ & $2.26 \%$ \\
\hline 1950 & & $1.35 \%$ & $1.32 \%$ & $1.56 \%$ & $1.91 \%$ & $0.28 \%$ & ----- & $1.10 \%$ & $4.17 \%$ & $3.02 \%$ & $22.94 \%$ & $4.69 \%$ \\
\hline 1960 & & $1.74 \%$ & $1.63 \%$ & $2.27 \%$ & $8.20 \%$ & $4.22 \%$ & ----- & $11.86 \%$ & $7.02 \%$ & $10.51 \%$ & $15.01 \%$ & $5.87 \%$ \\
\hline 970 & & $1.25 \%$ & $1.13 \%$ & $1.79 \%$ & 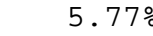 & $4.15 \%$ & ----- & $2.42 \%$ & $6.06 \%$ & $6.66 \%$ & $11.95 \%$ & $4.28 \%$ \\
\hline 1980 & & $1.09 \%$ & $0.58 \%$ & $1.60 \%$ & $13.99 \circ$ & $5.43 \%$ & ----- & $1.70 \%$ & $6.17 \%$ & $8.15 \%$ & $24.11 \%$ & $4.93 \%$ \\
\hline 1990 & & $0.93 \%$ & $0.58 \%$ & $1.24 \%$ & $4.89 \%$ & $3.62 \%$ & $7.31 \%$ & ----- & ----- & ----- & $1.99 \%$ & $4.25 \%$ \\
\hline & & $1.24 \%$ & $0.83 \%$ & $1.94 \%$ & $3.88 \%$ & $43 \%$ & $3 \%$ & $0.64 \%$ & $5.52 \%$ & & $-2.10 \%$ & $4.63 \%$ \\
\hline
\end{tabular}

$\backslash 1$ Includes races not shown separately.

$\backslash 2$ Revisions to include adjustments for underenumeration in the Southern states show a total (both sexes) of $34,337,292$ for whites and 5,392,172 for blacks.

13 In 1930 Mexicans were classified as nonwhite. This decision was changed by 1940, and revised tabulations were published. The revised population estimates are given here. The actual 1930 figures are: white (108,864,207), all other races $(1,428,303)$.

$\backslash 4$ Denotes first year for which figures include Alaska and Hawaii.

$\backslash 5$ The population of other races (i.e., neither white nor black) was overstated by about 327,000 in the 1970 census.

16 American Indian, Eskimo or Aleut in 1990.

17 American Indian and Alaska Native in 2000.

Source: 1790-1970, except Hispanic: U.S. Bureau of the Census [1975], Series A 91-104. 1980: U.S. Bureau of the Census [1983], Tables 40, 41. 1990: U.S. Bureau of the Census [1992], Table 13. 2000: U.S. Bureau of the Census, [2002].

Hispanic population: Gratton and Gutmann [2000], Table 2. 
Table 2. Hispanic Population by Race \& Ethnicity. 1850 to 2000.

\begin{tabular}{|c|c|c|c|c|c|c|c|c|c|c|c|}
\hline \multirow[b]{2}{*}{ Year } & \multirow[b]{2}{*}{ Total } & \multirow{2}{*}{$\begin{array}{l}\text { Mexican } \\
\text { Origin }\end{array}$} & \multirow{2}{*}{$\begin{array}{l}\text { Spanish } \\
\text { Origin }\end{array}$} & \multicolumn{2}{|l|}{ uerto } & \multicolumn{2}{|l|}{ Other } & \multicolumn{4}{|c|}{ Ameri- } \\
\hline & & & & Origin & Origin & Origin & Origin & White & Black & indian & Other \\
\hline 1850 & 116943 & 80959 & 4955 & 0 & 2124 & 1112 & 27793 & 114617 & 2326 & ----- & ----- \\
\hline 1880 & 393555 & 290642 & 32504 & 0 & 12267 & 11373 & 46769 & 337291 & 35319 & 20845 & 100 \\
\hline 1900 & 503189 & 401491 & 47055 & 0 & 22006 & 18216 & 14421 & & 18 & & 25047 \\
\hline 1910 & 797994 & 640104 & 69020 & 2937 & 34903 & 29616 & 21414 & 688709 & 23792 & 27318 & 58175 \\
\hline 1920 & 1286154 & & & 20384 & & 39465 & 70 & 121 & 36330 & & 16253 \\
\hline 1940 & 2021820 & 156 & 15 & 95129 & 49 & 86636 & 72 & 19 & 45 & & 3339 \\
\hline 1950 & 3231409 & 2489477 & 134659 & 326186 & 70919 & 117023 & 93145 & 3136623 & 70599 & & 7193 \\
\hline 1960 & 5814784 & 4087546 & 202822 & 1027338 & 163241 & 272972 & 60865 & 561 & 135389 & & 29690 \\
\hline 1970 & 0940 & 56 & 248439 & 1620777 & 63 & 70 & 67039 & & & 5 & 115903 \\
\hline 1980 & 14608673 & 8740439 & ---- & 2013945 & 803226 & 3051063 & ----- & 8115256 & 390852 & ----- & 6102565 \\
\hline 1990 & 22354059 & 13495938 & ----- & 2727754 & 1043932 & 5086435 & ----- & 11557774 & 769767 & 165461 & 9861057 \\
\hline 2000 & 35505818 & 20640711 & ----- & 3406178 & 1241685 & 10017244 & ----- & ----- & ----- & ----- & (c) \\
\hline
\end{tabular}

Source: 1850 - 1970: Brian Gratton and Myron P. Gutmann, "Hispanics in the United States, 1850-1990: Estimates of Population Size and National Origin," Historical Methods (2000), plus additional calculations using the IPUMS samples. 1980: U.S. Bureau of the Census [1983, 1984]. 1990: U.S. Bureau of the Census [1992, 1993b]. 2000: U.S. Bureau of the Census $[2002]$. 
TABLE 3. Fertility and Mortality by Race. United States, 1800-1998.

\begin{tabular}{|c|c|c|c|c|c|c|c|c|c|c|}
\hline \multirow[t]{2}{*}{$\begin{array}{l}\text { APPROX } \\
\text { DATE }\end{array}$} & \multicolumn{2}{|c|}{ BIRTHRATE (a) } & \multicolumn{2}{|c|}{$\begin{array}{l}\text { CHILD-WOMAN } \\
\text { RATIO (b) }\end{array}$} & \multicolumn{2}{|c|}{$\begin{array}{l}\text { TOTAL FERTI- } \\
\text { LITY RATE (c) }\end{array}$} & \multicolumn{2}{|c|}{$\begin{array}{l}\text { EXPECTATION } \\
\text { OF LIFE }(d)\end{array}$} & \multicolumn{2}{|c|}{$\begin{array}{l}\text { INFANT MORTAL- } \\
\text { ITY RATE (e) }\end{array}$} \\
\hline & WHITE & BLACK (f) & WHITE & BLACK & WHITE & BLACK (f) & WHITE BL & $\mathrm{ACK}(\mathrm{f})$ & WHITE BLI & $\operatorname{ACK}(f)$ \\
\hline 1800 & 55.0 & & 1342 & & 7.04 & & & & & \\
\hline 1810 & 54.3 & & 1358 & & 6.92 & & & & & \\
\hline 1820 & 52.8 & & 1295 & 1191 & 6.73 & & & & & \\
\hline 1830 & 51.4 & & 1145 & 1220 & 6.55 & & & & & \\
\hline 1840 & 48.3 & & 1085 & 1154 & 6.14 & & & & & \\
\hline 1850 & 43.3 & 58 & 892 & 1087 & 5.42 & & 39.5 & 23.0 & 216.8 & 340.0 \\
\hline 1860 & 41.4 & $55.0(\mathrm{~h})$ & 905 & 1072 & & $7.58(\mathrm{~h})$ & 43.6 & & 181.3 & \\
\hline 1870 & 38.3 & 55.4 (i) & 814 & 997 & 4.55 & 7.69 (i) & 45.2 & & 175.5 & \\
\hline 1880 & 35.2 & $51.9(j)$ & 780 & 1090 & 4.24 & & 40.5 & & 214.8 & \\
\hline 1890 & 31.5 & 48.1 & 685 & 930 & 3.87 & 6.56 & 46.8 & & 150.7 & \\
\hline 1900 & 30.1 & 44.4 & 666 & 845 & 3.56 & 5.61 & $51.8(\mathrm{k})$ & $41.8(k)$ & $110.8(\mathrm{k})$ & 170.3 \\
\hline 1910 & 29.2 & 38.5 & 631 & 736 & 3.42 & 4.61 & $54.6(1)$ & $46.8(1)$ & $96.5(1)$ & 142.6 \\
\hline 1920 & 26.9 & 35.0 & 604 & 608 & 3.17 & 3.64 & 57.4 & 47.0 & 82.1 & 131.7 \\
\hline 1930 & 20.6 & 27.5 & 506 & 554 & 2.45 & 2.98 & 60.9 & 48.5 & 60.1 & 99.9 \\
\hline 1940 & 18.6 & 26.7 & 419 & 513 & 2.22 & 2.87 & 64.9 & 53.9 & 43.2 & 73.8 \\
\hline 1950 & 23.0 & 33.3 & 580 & 663 & 2.98 & 3.93 & 69.0 & 60.7 & 26.8 & 44.5 \\
\hline 1960 & 22.7 & 32.1 & 717 & 895 & 3.53 & 4.52 & 70.7 & 63.9 & 22.9 & 43.2 \\
\hline 1970 & 17.4 & 25.1 & 507 & 689 & 2.39 & 3.07 & 71.6 & 64.1 & 17.8 & 30.9 \\
\hline 1980 & 15.1 & 21.3 & 365 & 507 & 1.77 & 2.18 & 74.5 & 68.5 & 10.9 & 22.2 \\
\hline 1990 & 15.8 & 22.4 & 355 & 458 & 2.00 & 2.48 & 76.1 & 69.1 & 7.6 & 18.0 \\
\hline 1998 & 14.6 & 17.7 & & & 2.07 & 2.17 & 77.3 & 71.3 & 6.0 & 14.3 \\
\hline
\end{tabular}

(a) Births per 1000 population per annum.

(b) Children aged 0-4 per 1,000 women aged 20-44. Taken from U.S. Bureau of the Census, [1975], Series 67-68 for 1800-1970. For the black population 1820-1840, Thompson and Whelpton, [1933], Table 74, adjusted upward 47\% for relative under-enumeration of black children aged 0-4 for the censuses of 1820-1840.

(c) Total number of births per woman if she experienced the current period age-specific fertility rates throughout her life.

(d) Expectation of life at birth for both sexes combined.

(e) Infant deaths per 1000 live births per annum.

(f) Black and other population for CBR (1920-1970), TFR (1940-1990), e(0) (1950-1960), IMR (19201970).

(g) Average for 1850-59.

(h) Average for 1860-69.

(i) Average for 1870-79.

(j) Average for 1880-84.

(k) Approximately 1895.

(l) Approximately 1904 .

SOURCE: 1800-1990: U.S. Bureau of the Census, [1975, 1986, 1997]. Coale and Zelnik, [1963]. Coale and Rives, [1973]. Haines, [1998]. Preston and Haines, [1991], Table 2.5. Steckel, [1986]. For 1998, see Tables 4-6 below. 
Table 4. Crude Birth Rate and General Fertility Rate. By Race \& Ethnicity. United States, 1800 to 1998 . \1

\begin{tabular}{|c|c|c|c|c|c|c|c|c|c|c|c|c|}
\hline \multicolumn{13}{|c|}{ CRUDE BIRTH RATE } \\
\hline Total & White & & Black & & indian & ac. Isl & Total & White & other & Black & indian & Pac. Is \\
\hline & 55.0 & & ------- & & ------ & --- & ------- & 278.0 & ---- & ------- & ------ & --- \\
\hline------ & 54.3 & --- & ------- & & ------- & --- & ------- & 274.0 & --- & --- & ------- & --- \\
\hline 55.2 & 52.8 & ------- & ------- & & ------- & ------- & ------- & 260.0 & ------- & ------- & ------- & --- \\
\hline$-\ldots$ & 51.4 & ------- & ------- & & ------- & ------- & ------- & 240.0 & --- & --- & ------- & --- \\
\hline 51.8 & 48.3 & ---- & ------- & & ------- & ------- & ------- & 222.0 & -- & --- & ------- & --- \\
\hline--- & 43.3 & ------- & ------- & & ------- & ------- & ------- & 194.0 & 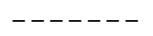 & --- & --1 & \\
\hline----- & 42.8 & ---- & 58.6 & $\backslash 5$ & ------- & ------- & ------- & & & & & \\
\hline 44.3 & 41.8 & --- & ---- & & ------ & --- & ------- & 184.0 & & & & \\
\hline--- & 35.4 & ---- & 55.1 & $\backslash 6$ & ------- & ------- & ------- & & & & & \\
\hline----- & 37.1 & --- & ----- & & ------- & ------- & ------- & 167.0 & & --- & 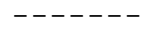 & $=--$ \\
\hline---- & 36.8 & ----- & 55.4 & $\backslash 7$ & ------- & ------- & ------- & & & -- & --- & --- \\
\hline 39.8 & 33.6 & ------- & 51.9 & $\backslash 8$ & ------- & ------- & ------- & 155.0 & --- & ------- & ------- & ------- \\
\hline & 31.2 & ------- & 48.1 & & ------- & ------- & ------- & 137.0 & --- & ------- & ------- & ------- \\
\hline 32.3 & 28.5 & ----- & 44.4 & & ------- & ------- & ------- & 130.0 & & ------- & ------- & ------- \\
\hline 30.0 & 29.2 & ---- & ------- & & ------- & ------- & 126.8 & 123.6 & --- & ------- & ------- & ------- \\
\hline 30.1 & 29.2 & ------- & 38.5 & & ------- & ------- & 126.8 & 123.8 & --- & ------- & ------- & ------- \\
\hline 29.9 & 29.1 & ---- & ------- & & ------- & ------- & 126.3 & 123.6 & --- & ------- & ------- & ------- \\
\hline 29.8 & 29.0 & ---- & ------- & & ------- & ------- & 125.8 & 123.3 & --- & ------- & ------- & ----- \\
\hline 29.5 & 28.8 & ------- & ------- & & ------- & ------- & 124.7 & 122.4 & --- & ------- & ------- & ------- \\
\hline 29.9 & 29.3 & ---- & ------- & & ------- & ------- & 126.6 & 124.6 & --- & ------- & ------ & ------- \\
\hline 29.5 & 28.9 & ------- & 34.4 & & ------- & ------- & 125.0 & 123.2 & -- & ------- & ------- & ------- \\
\hline 29.1 & 28.5 & ------- & ------- & & ------- & ------- & 123.4 & 121.8 & -- & ------- & ------- & ------- \\
\hline 28.5 & 27.9 & 32.9 & ------- & & ------- & ------- & 121.0 & (NA) & -- & ------- & --- & --- \\
\hline 28.2 & 27.6 & 33.0 & ------- & & ------- & ------- & 119.8 & (NA) & & --- & ------- & ------- \\
\hline 26.1 & 25.3 & 32.4 & ------- & & ------- & ------- & 111.2 & (NA) & --- & ------- & ------- & ------- \\
\hline 27.7 & 26.9 & 35.0 & ------- & & ------- & ------- & 117.9 & 115.4 & 137.5 & ------- & ------- & ------- \\
\hline 28.1 & 27.3 & 35.8 & ------- & & ------- & ------- & 119.8 & 117.2 & 140.8 & ------- & ------- & ------- \\
\hline 26.2 & 25.4 & 33.2 & ------- & & ------- & -------- & 111.2 & 108.8 & 130.8 & ------- & ------- & ------- \\
\hline 26.0 & 25.2 & 33.2 & ------- & & ------- & ------- & 110.5 & 108.0 & 130.5 & ------- & ------- & ------- \\
\hline 26.1 & 25.1 & 34.6 & ------- & & ------- & ------- & 110.9 & 107.8 & 135.6 & ------- & ------- & ------- \\
\hline 25.1 & 24.1 & 34.2 & ------- & & ------- & ------- & 106.6 & 103.3 & 134.0 & ------- & ------- & ------- \\
\hline 24.2 & 23.1 & 33.4 & ------- & & ------- & ------- & 102.6 & 99.2 & 130.3 & ------- & ------- & ------- \\
\hline 23.5 & 22.7 & 31.1 & ------- & & ------- & ------- & 99.8 & 97.1 & 121.7 & ------- & ------- & ------- \\
\hline 22.2 & 21.5 & 28.5 & ------- & & ------- & ------- & 93.8 & 91.7 & 111.0 & ------- & ------- & ------- \\
\hline 21.2 & 20.5 & 27.3 & ------- & & ------- & ------- & 89.3 & 87.3 & 106.1 & ------- & ------- & ------- \\
\hline
\end{tabular}


Table 4 (cont.)

CRUDE BIRTH RATE

\begin{tabular}{|c|c|c|c|c|c|}
\hline \multicolumn{6}{|c|}{ All } \\
\hline 1930 & & 21.3 & 20.6 & 27.5 & \\
\hline 1931 & & 20.2 & 19.5 & 26.6 & ----- \\
\hline 1932 & & 19.5 & 18.7 & 26.9 & ------- \\
\hline 1933 & & 18.4 & 17.6 & 25.5 & ---- \\
\hline 1934 & & 19.0 & 18.1 & 26.3 & ------- \\
\hline 1935 & & 18.7 & 17.9 & 25.8 & ------- \\
\hline 1936 & & 18.4 & 17.6 & 25.1 & ------- \\
\hline 1937 & & 18.7 & 17.9 & 26.0 & ------- \\
\hline 1938 & & 19.2 & 18.4 & 26.3 & ------- \\
\hline 1939 & & 18.8 & 18.0 & 26.1 & ------- \\
\hline 1940 & & 19.4 & 18.6 & 26.7 & ------- \\
\hline 1941 & & 20.3 & 19.5 & 27.3 & ------- \\
\hline 1942 & & 22.2 & 21.5 & 27.7 & ------- \\
\hline 1943 & & 22.7 & 22.1 & 28.3 & ------- \\
\hline 1944 & & 21.2 & 20.5 & 27.4 & ------- \\
\hline 1945 & & 20.4 & 19.7 & 26.5 & ------- \\
\hline 1946 & & 24.1 & 23.6 & 28.4 & ------- \\
\hline 1947 & & 26.6 & 26.1 & 31.2 & ------- \\
\hline 1948 & & 24.9 & 24.0 & 32.4 & ------- \\
\hline 1949 & & 24.5 & 23.6 & 33.0 & ------- \\
\hline 1950 & & 24.1 & 23.0 & 33.3 & ------- \\
\hline 1951 & & 24.9 & 23.9 & 33.7 & ------- \\
\hline 1952 & & 25.1 & 24.1 & 33.4 & ------- \\
\hline 1953 & & 25.1 & 24.0 & 33.9 & ------- \\
\hline 1954 & & 25.3 & 24.2 & 34.7 & ------- \\
\hline 1955 & & 25.0 & 23.8 & 34.5 & ------- \\
\hline 1956 & & 25.2 & 24.0 & 35.1 & ------- \\
\hline 1957 & & 25.3 & 24.0 & 35.0 & ------- \\
\hline 1958 & & 24.5 & 23.3 & 34.0 & ------- \\
\hline 1959 & $\backslash 2$ & 24.0 & 22.9 & 32.9 & ------- \\
\hline 1960 & $\backslash 3$ & 23.7 & 22.7 & 32.1 & 31.9 \\
\hline 1961 & & 23.3 & 22.2 & 31.6 & ----- \\
\hline 1962 & $\backslash 4$ & 22.4 & 21.4 & 30.5 & ----- \\
\hline 63 & $\backslash 4$ & 21.7 & 20.7 & 29.7 & ----- \\
\hline & & 21.1 & 20.0 & 29.2 & 29 \\
\hline
\end{tabular}

GENERAL FERTILITY RATE

\begin{tabular}{|c|c|c|c|c|c|c|c|}
\hline $\begin{array}{l}\text { Amer- } \\
\text { indian }\end{array}$ & $\begin{array}{l}\text { Asian \& } \\
\text { Pac. Isl }\end{array}$ & Total & White & $\begin{array}{c}\text { All } \\
\text { other }\end{array}$ & Black & $\begin{array}{l}\text { Amer- } \\
\text { indian }\end{array}$ & $\begin{array}{l}\text { Asian \& } \\
\text { Pac. Is I }\end{array}$ \\
\hline & & 89.2 & 87.1 & 105.9 & ------- & ------ & ------ \\
\hline-- & ------- & 84.6 & 82.4 & 102.1 & -- & --- & \\
\hline----- & ------- & 81.7 & 79.0 & 103.0 & ------- & ------- & \\
\hline---- & ------- & 76.3 & 73.7 & 97.3 & ------- & --- & \\
\hline------ & ------- & 78.5 & 75.8 & 100.4 & ---- & --- & \\
\hline----- & ------- & 77.2 & 74.5 & 98.4 & ------- & ------- & $=-$ \\
\hline----- & ------- & 75.8 & 73.3 & 95.9 & ------- & ------- & \\
\hline--- & ------- & 77.1 & 74.4 & 99.4 & ----- & ---- & \\
\hline----- & ------- & 79.1 & 76.5 & 100.5 & ------- & ------- & --- \\
\hline----- & ------- & 77.6 & 74.8 & 100.1 & ------- & ------- & \\
\hline 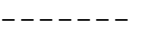 & ------- & 79.9 & 77.1 & 102.4 & ---- & ------- & \\
\hline------ & ------- & 83.4 & 80.7 & 105.4 & ------- & ------- & --- \\
\hline 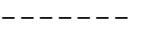 & ------- & 91.5 & 89.5 & 107.6 & ------- & ------- & \\
\hline-- & --- & 94.3 & 92.3 & 111.0 & ------- & ------- & \\
\hline 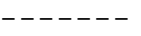 & ------- & 88.8 & 86.3 & 108.5 & ------- & ------- & --- \\
\hline- & ------- & 85.9 & 83.4 & 106.0 & ------- & ------- & -- \\
\hline c- & ------- & 101.9 & 100.4 & 113.9 & ------- & ------- & \\
\hline-- & ------- & 113.3 & 111.8 & 125.9 & ------- & ------- & --- \\
\hline----1 & ------- & 107.3 & 104.3 & 131.6 & ------- & ------- & --- \\
\hline & ------- & 107.1 & 103.6 & 135.1 & ------- & --- & \\
\hline & --- & 106.2 & 102.3 & 137.3 & ------- & --- & \\
\hline 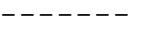 & ------- & 111.4 & 107.7 & 141.7 & ------- & ------- & --- \\
\hline & -------- & 113.8 & 110.0 & 142.7 & ------- & ------- & \\
\hline & --- & 115.0 & 110.9 & 146.4 & ------- & ------- & \\
\hline--- & ------- & 117.9 & 113.5 & 152.2 & ------- & ------- & --- \\
\hline & & 118.3 & 113.7 & 154.3 & ------- & ------- & \\
\hline & --- & 121.0 & 115.9 & 159.7 & ------- & ------- & --- \\
\hline--- & ------- & 122.7 & 117.6 & 161.7 & ------- & ------- & --- \\
\hline & -1 & 120.0 & 114.8 & 159.1 & ------- & ------- & --- \\
\hline & --- & 118.8 & 113.9 & 156.0 & ------- & --- & --- \\
\hline--- & ------- & 118.0 & 113.2 & 153.6 & 153.5 & ------- & --- \\
\hline & -- & 117.1 & 112.3 & 153.0 & ----- & ------- & --- \\
\hline & & 112.0 & 107.5 & 147.8 & ----- & & \\
\hline- & ------- & 108.3 & 103.6 & 143.7 & ----- & ------- & --- \\
\hline & - & 104.7 & 99.8 & 1 & 6 & ----- & - \\
\hline
\end{tabular}


Table 4 (cont.)

CRUDE BIRTH RATE

\begin{tabular}{lrrrr} 
Year & Total & White & \multicolumn{1}{c}{ All } \\
1965 & 19.4 & 18.3 & 27.6 & \multicolumn{1}{c}{ Black } \\
1966 & 18.4 & 17.4 & 26.1 & 26.2 \\
$1967 \backslash 5$ & 17.8 & 16.8 & 25.0 & 25.1 \\
1968 & 17.6 & 16.6 & 24.2 & 24.2 \\
1969 & 17.9 & 16.9 & 24.5 & 24.4 \\
1970 & 18.4 & 17.4 & 25.1 & 25.3 \\
1971 & 17.2 & 16.1 & 24.6 & 24.4 \\
1972 & 15.6 & 14.5 & 22.8 & 22.5 \\
1973 & 14.8 & 13.8 & 21.7 & 21.4 \\
1974 & 14.8 & 13.9 & 21.2 & 20.8 \\
1975 & 14.6 & 13.6 & 21.0 & 20.7 \\
1976 & 14.6 & 13.6 & 20.8 & 20.5 \\
1977 & 15.1 & 14.1 & 21.6 & 21.4 \\
1978 & 15.0 & 14.0 & 21.6 & 21.3 \\
1979 & 15.6 & 14.5 & 22.2 & 22.0 \\
1980 & 15.9 & 15.1 & 21.3 & 21.3 \\
1981 & 15.8 & 15.0 & 20.8 & 20.8 \\
1982 & 15.9 & 15.1 & 20.7 & 20.7 \\
1983 & 15.6 & 14.8 & 20.1 & 20.2 \\
1984 & 15.6 & 15.0 & 20.0 & 20.1 \\
1985 & 15.8 & 14.8 & 20.1 & 20.4 \\
1986 & 15.6 & 14.9 & 20.1 & 20.5 \\
1987 & 15.7 & 15.0 & 20.4 & 20.8 \\
1988 & 16.0 & 15.4 & 21.0 & 21.5 \\
1989 & 16.4 & 15.4 & 21.6 & 22.3 \\
1990 & 16.7 & 15.8 & 21.7 & 22.4 \\
1991 & 16.3 & 15.4 & 21.1 & 21.9 \\
1992 & 15.9 & 15.0 & 20.5 & 21.3 \\
1993 & 15.5 & 14.7 & 19.7 & 20.5 \\
1994 & 15.2 & 14.4 & 18.9 & 19.5 \\
1995 & 14.8 & 14.2 & 17.9 & 18.2 \\
1996 & 14.7 & 14.1 & 17.5 & 17.8 \\
1997 & 14.5 & 13.9 & ----1 & 17.7 \\
1998 & 14.6 & 14.0 & ------1 & 17.7
\end{tabular}

GENERAL FERTILITY RATE

\begin{tabular}{|c|c|c|}
\hline Amer- & sian & \\
\hline ian & Pac. Is] & Total \\
\hline--- & ------- & 96.3 \\
\hline---- & -------- & 90.8 \\
\hline--- & ---- & 87.2 \\
\hline---- & ------- & 85.2 \\
\hline--- & ------- & 86.1 \\
\hline & & 87.9 \\
\hline--- & ------- & 81.6 \\
\hline- & ---- & 73.1 \\
\hline & & 68.8 \\
\hline--- & ---- & 67.8 \\
\hline----1 & ---- & 66.0 \\
\hline- & & 65.0 \\
\hline---- & ---- & 66.8 \\
\hline----1 & ------- & 65.5 \\
\hline-- & & 67.2 \\
\hline 20.7 & 19.9 & 68.4 \\
\hline 20.0 & 20.1 & 67.3 \\
\hline 21.1 & 20.3 & 67.3 \\
\hline 20.6 & 19.5 & 65.7 \\
\hline 20.1 & 18.8 & 65.5 \\
\hline 19.8 & 18.7 & 66.3 \\
\hline 19.2 & 18.0 & 65.4 \\
\hline 19.1 & 18.4 & 65.8 \\
\hline 19.3 & 19.2 & 67.3 \\
\hline 19.7 & 18.7 & 69.2 \\
\hline 18.9 & 19.0 & 70.9 \\
\hline 18.3 & 18.2 & 69.6 \\
\hline 18.4 & 18.0 & 68.9 \\
\hline 17.8 & 17.7 & 67.6 \\
\hline 17.1 & 17.5 & 66.7 \\
\hline 16.6 & 17.3 & 65.6 \\
\hline 16. & 17.0 & 65.3 \\
\hline 16.6 & 16.9 & 65.0 \\
\hline & 164 & 6 \\
\hline
\end{tabular}

\begin{tabular}{lr} 
White & \multicolumn{1}{c}{$\begin{array}{c}\text { All } \\
\text { other }\end{array}$} \\
91.3 & 131.9 \\
86.2 & 123.5 \\
82.8 & 117.1 \\
81.3 & 111.9 \\
82.2 & 111.6 \\
84.1 & 113.0 \\
77.3 & 109.1 \\
68.9 & 99.5 \\
64.9 & 93.4 \\
64.2 & 89.8 \\
62.5 & 87.7 \\
61.5 & 85.8 \\
63.2 & 87.7 \\
61.7 & 87.0 \\
63.4 & 88.5 \\
65.6 & 83.9 \\
64.8 & 81.1 \\
64.8 & 80.3 \\
63.4 & 77.9 \\
63.2 & 77.0 \\
64.1 & 77.3 \\
63.1 & 76.8 \\
63.3 & 77.8 \\
64.5 & 80.3 \\
66.4 & 82.7 \\
68.3 & 83.2 \\
67.0 & 81.5 \\
66.5 & 79.5 \\
65.4 & 77.1 \\
64.9 & 74.4 \\
64.4 & 70.7 \\
64.3 & 69.6 \\
63.9 & ------ \\
71.0 & ------
\end{tabular}

$\begin{array}{rrr}\text { Black } & \begin{array}{c}\text { Amer- } \\ \text { indian }\end{array} & \text { Asian } \text { Pac. Isl } \\ 133.2 & ------- & ------- \\ 124.7 & ------- & ------- \\ 118.5 & ------- & ------- \\ 112.7 & ------- & ------ \\ 112.1 & ------- & ------ \\ 115.4 & ------- & ------- \\ 109.7 & ------- & ------- \\ 99.9 & ------- & ------- \\ 93.6 & ------- & ------ \\ 89.7 & ------- & ------ \\ 87.9 & ------- & ------ \\ 85.8 & ------- & ------ \\ 88.1 & ------- & ------- \\ 86.7 & ------- & ------- \\ 88.3 & ------- & ------ \\ 84.7 & 82.7 & 73.2 \\ 82.0 & 79.6 & 73.7 \\ 80.9 & 83.6 & 74.8 \\ 78.7 & 81.8 & 71.7 \\ 78.2 & 79.8 & 69.2 \\ 78.8 & 78.6 & 68.4 \\ 78.9 & 75.9 & 66.0 \\ 80.1 & 75.6 & 67.1 \\ 82.6 & 76.8 & 70.2 \\ 86.2 & 79.0 & 68.2 \\ 86.8 & 76.2 & 69.6 \\ 85.2 & 75.1 & 67.6 \\ 83.2 & 75.4 & 67.2 \\ 80.5 & 73.4 & 66.7 \\ 76.9 & 70.9 & 66.8 \\ 72.3 & 69.1 & 66.4 \\ 70.7 & 68.7 & 65.9 \\ 70.7 & 69.1 & 66.3 \\ 71.0 & 70.7 & 64.0\end{array}$

Footnotes:

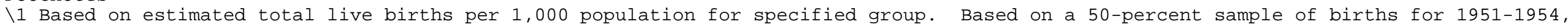

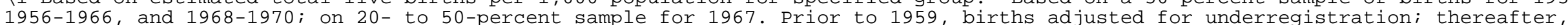

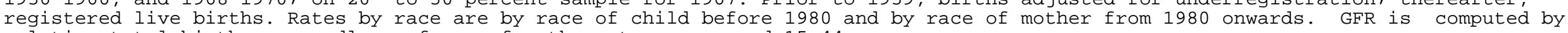
relating total births, regardless of age of mother, to women aged 15-44 years.

$\backslash 2$ Includes Alaska.

$\backslash 2$ First year for which figures include Alaska and Hawaii.

$\backslash 4$ Figures by race exclude New Jersey; State did not require reporting of race.

15 Based on 20- to 50-percent sample of births.

$17 \quad 1860-69$.

$18 \quad 1870-79$.

19 1880-84. 


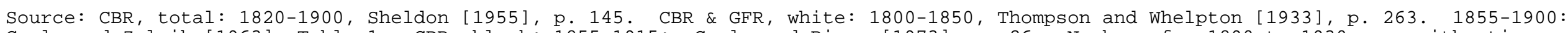

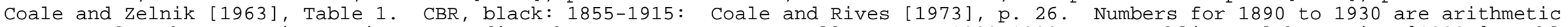

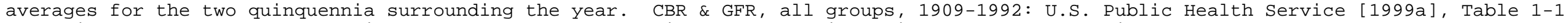

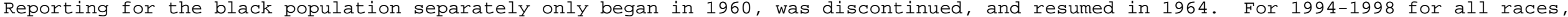

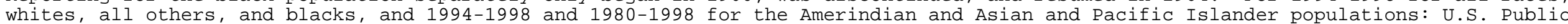
Health Service [2000a], Table 1. 
Table 5. Total Fertility Rate, by Race \& Ethnicity. United States, 1800 to $1998 . \backslash 1$

\begin{tabular}{|c|c|c|c|c|c|c|c|}
\hline Year & Total & White & $\begin{array}{c}\text { All } \\
\text { Other }\end{array}$ & Black & $\begin{array}{l}\text { Amer- } \\
\text { indian }\end{array}$ & $\begin{array}{l}\text { Asian \& } \\
\text { Pacific } \\
\text { Islander }\end{array}$ & $\begin{array}{l}\text { Hispanic- } \\
\text { Origin }\end{array}$ \\
\hline 1800 & ----- & 7040.0 & ----- & ----- & ----- & ----- & ----- \\
\hline 1810 & ----- & 6920.0 & ----- & ----- & ----- & ----- & ----- \\
\hline 1820 & ----- & 6730.0 & ----- & ----- & ----- & ---1 & ----- \\
\hline 1830 & ----- & 6550.0 & ---- & ----- & ----- & ----- & ----- \\
\hline 1840 & ----- & 6140.0 & ---- & ----- & ----- & ----- & ----- \\
\hline 1850 & ----- & 5420.0 & ----- & ----- & ----- & ----- & ----- \\
\hline $1850 / 59$ & ----- & ----- & ----- & 7900.0 & ----- & ----- & ----- \\
\hline 1860 & ----- & 5210.0 & ----- & ----- & ----- & ----- & ----- \\
\hline $1860 / 69$ & ----- & ----- & ----- & 7580.0 & ----- & ----- & ----- \\
\hline 1870 & ----- & 4550.0 & ----- & ----- & ----- & ----- & ----- \\
\hline $1870 / 79$ & ----- & ----- & ----- & 7690.0 & ----- & ----- & ----- \\
\hline 1880 & ----- & 4240.0 & ----- & ----- & ----- & ----- & ----- \\
\hline $1880 / 84$ & ----- & ----- & ----- & 7260.0 & ----- & ----- & ----- \\
\hline 1890 & ----- & 3870.0 & ----- & 6560.0 & ----- & ----- & ----- \\
\hline 1900 & ----- & 3560.0 & ----- & 5610.0 & ----- & ----- & ----- \\
\hline $1905 / 10$ & 3551.0 & 3443.0 & ----- & 4351.0 & ----- & ----- & ----- \\
\hline 1910 & $(\mathrm{NA})$ & 3420.0 & ----- & 4610.0 & ----- & ----- & ----- \\
\hline 1920 & (NA) & 3170.0 & ----- & 3640.0 & ----- & ----- & ----- \\
\hline 1930 & (NA) & 2450.0 & ----- & 2980.0 & ----- & ----- & ----- \\
\hline 1933 & 2210.3 & 2116.2 & 2962.4 & ----- & ----- & ----- & ----- \\
\hline 1934 & 2274.3 & 2172.4 & 3098.9 & ----- & ----- & ----- & ----- \\
\hline 1935 & 2235.2 & 2170.7 & 2728.0 & ----- & ----- & ----- & ----- \\
\hline 1936 & 2193.3 & 2131.1 & 2660.5 & ----- & ----- & ----- & ----- \\
\hline 1937 & 2224.8 & 2155.9 & 2755.7 & ----- & ----- & ----- & ----- \\
\hline 1938 & 2280.5 & 2213.9 & 2789.5 & ----- & ----- & ----- & ----- \\
\hline 1939 & 2232.4 & 2161.1 & 2779.9 & ----- & ----- & ----- & ----- \\
\hline 1940 & 2301.3 & 2229.0 & 2870.0 & 2870.0 & ----- & ----- & ----- \\
\hline 1941 & 2399.0 & 2328.0 & 2956.0 & ----- & ----- & ----- & ----- \\
\hline 1942 & 2628.0 & 2577.0 & 3022.0 & ----- & ----- & ----- & ----- \\
\hline 1943 & 2718.0 & 2664.0 & 3128.0 & ----- & ----- & ----- & ----- \\
\hline 1944 & 2568.0 & 2501.0 & 3075.0 & ----- & ----- & ----- & ----- \\
\hline 1945 & 2491.0 & 2421.0 & 3017.0 & ----- & ----- & ----- & ----- \\
\hline 1946 & 2943.0 & 2901.0 & 3238.0 & ----- & ----- & ----- & ----- \\
\hline 1947 & 3274.0 & 3230.0 & 3575.0 & ----- & ----- & ----- & ----- \\
\hline 1948 & 3109.0 & 3022.0 & 3742.0 & ----- & ----- & ----- & ----- \\
\hline 1949 & 3110.0 & 3009.0 & 3855.0 & ----- & ----- & ----- & ----- \\
\hline 1950 & 3091.0 & 2977.0 & 3928.0 & 3930.0 & ----- & --- & ----- \\
\hline 1951 & 3269.0 & 3157.0 & 4091.0 & ----- & ----- & ----- & ----- \\
\hline 1952 & 3358.0 & 3250.0 & 4147.0 & ----- & ----- & ----- & ----- \\
\hline 1953 & 3424.0 & 3306.0 & 4283.0 & ----- & ----- & ----- & ----- \\
\hline 1954 & 3543.0 & 3415.0 & 4474.0 & ----- & ----- & ----- & ----- \\
\hline 1955 & 3580.0 & 3446.0 & 4550.0 & ----- & ----- & -- & ----- \\
\hline 1956 & 3689.0 & 3546.0 & 4730.0 & ----- & ----- & ----- & ----- \\
\hline 1957 & 3767.0 & 3625.0 & 4798.0 & ----- & ----- & ----- & ----- \\
\hline 1958 & 3701.0 & 3560.0 & 4727.0 & ----- & ----- & ----- & ----- \\
\hline 1959 & 3670.0 & 3544.0 & 4595.0 & ----- & ----- & ----- & ----- \\
\hline $1960 \backslash 2$ & 3653.6 & 3532.9 & 4522.1 & 4541.8 & ----- & ----- & ----- \\
\hline 1961 & 3620.3 & 3496.9 & 4496.8 & ----- & ----- & ----- & ----- \\
\hline $1962 \backslash 3$ & 3461.3 & 3341.3 & 4340.1 & ----- & ----- & ----- & ----- \\
\hline $1963 \backslash 3$ & 3318.8 & 3193.5 & 4203.0 & ----- & ----- & ----- & ----- \\
\hline
\end{tabular}


Table 5 (cont.)

\begin{tabular}{|c|c|c|c|c|c|c|c|}
\hline Year & Total & White & $\begin{array}{c}\text { All } \\
\text { Other }\end{array}$ & Black & $\begin{array}{c}\text { Amer- } \\
\text { indian }\end{array}$ & $\begin{array}{l}\text { Asian \& } \\
\text { Pacific } \\
\text { Islander }\end{array}$ & $\begin{array}{l}\text { Hispanic- } \\
\text { Origin }\end{array}$ \\
\hline 1964 & 3190.5 & 3065.0 & 4070.2 & 4138.6 & ----- & ----- & ----- \\
\hline 1965 & 2912.6 & 2783.4 & 3807.9 & 3828.5 & ----- & ----- & ----- \\
\hline 1966 & 2721.4 & 2602.9 & 3531.5 & 3545.3 & ----- & ----- & ----- \\
\hline 1967 & 2557.7 & 2446.9 & 3299.2 & 3311.8 & ----- & ----- & ----- \\
\hline 1968 & 2464.2 & 2365.6 & 3108.4 & 3099.8 & ----- & ----- & ----- \\
\hline 1969 & 2455.5 & 2360.3 & 3061.2 & 3042.8 & ----- & ----- & ----- \\
\hline 1970 & 2480.0 & 2385.0 & 3066.7 & 3099.5 & ----- & ----- & ----- \\
\hline 1971 & 2266.5 & 2160.5 & 2919.5 & 2902.0 & ----- & ----- & ----- \\
\hline 1972 & 2010.0 & 1906.5 & 2627.5 & 2601.0 & ----- & ----- & ----- \\
\hline 1973 & 1879.0 & 1783.0 & 2443.0 & 2411.0 & ----- & ----- & ----- \\
\hline 1974 & 1835.0 & 1748.5 & 2338.5 & 2298.5 & ----- & ----- & ----- \\
\hline 1975 & 1774.0 & 1686.0 & 2276.0 & 2243.0 & ----- & ----- & ----- \\
\hline 1976 & 1738.0 & 1652.0 & 2222.5 & 2187.0 & ----- & ----- & ----- \\
\hline 1977 & 1789.5 & 1703.0 & 2278.5 & 2251.0 & ----- & ----- & ----- \\
\hline 1978 & 1760.0 & 1667.5 & 2264.5 & 2218.0 & ----- & ----- & ----- \\
\hline 1979 & 1808.0 & 1715.5 & 2309.5 & 2263.2 & ----- & --- & ----- \\
\hline 1980 & 1839.5 & 1773.0 & 2199.0 & 2176.5 & 2162.5 & 1953.5 & ----- \\
\hline 1981 & 1812.0 & 1748.0 & 2133.5 & 2117.5 & 2090.0 & 1976.0 & ----- \\
\hline 1982 & 1827.5 & 1767.0 & 2132.0 & 2106.5 & 2213.0 & 2015.5 & ----- \\
\hline 1983 & 1799.0 & 1740.5 & 2084.0 & 2066.0 & 2180.5 & 1943.5 & ----- \\
\hline 1984 & 1806.5 & 1748.5 & 2078.5 & 2070.5 & 2136.0 & 1892.0 & ----- \\
\hline 1985 & 1844.0 & 1787.0 & 2106.5 & 2109.0 & 2128.0 & 1885.0 & ----- \\
\hline 1986 & 1837.5 & 1776.0 & 2114.5 & 2135.5 & 2082.0 & 1836.0 & ----- \\
\hline 1987 & 1872.0 & 1804.5 & 2168.5 & 2198.0 & 2099.0 & 1886.0 & ----- \\
\hline 1988 & 1934.0 & 1856.5 & 2264.5 & 2298.0 & 2153.5 & 1983.5 & ----- \\
\hline 1989 & 2014.0 & 1931.0 & 2360.5 & 2432.5 & 2247.0 & 1947.5 & 2014.0 \\
\hline 1990 & 2081.0 & 2003.0 & 2398.0 & 2480.0 & 2183.0 & 2002.5 & 2081.0 \\
\hline 1991 & 2073.0 & 1995.5 & 2383.0 & 2480.0 & 2169.0 & 1956.0 & 2073.0 \\
\hline 1992 & 2065.0 & 1993.5 & 2343.0 & 2442.0 & 2190.0 & 1942.0 & 2065.0 \\
\hline 1993 & 2046.0 & 1982.0 & 2293.5 & 2384.5 & 2141.0 & 1935.5 & 2046.0 \\
\hline 1994 & 2036.0 & 1985.0 & 2300.0 & 2300.0 & 2080.0 & 1943.0 & 2036.0 \\
\hline 1995 & 2019.0 & 1989.0 & 2175.0 & 2175.0 & 2033.5 & 1924.0 & 2019.0 \\
\hline 1996 & 2027.0 & 2005.5 & 2149.0 & 2144.0 & 2030.0 & 1907.5 & 2027.0 \\
\hline $1997 \backslash 4$ & 2032.5 & 2009.0 & ----- & 2154.0 & 2047.5 & 1925.5 & 2032.5 \\
\hline 1998 & 2058.5 & 2041.0 & ----- & 2171.0 & 2090.5 & 1867.5 & 2058.5 \\
\hline
\end{tabular}

$\backslash 1$ Total fertility rates are the sums of birth rates, by age of mother, multiplied by 5 . Birth rates are live births per 1,000 women in the specified groups. Beginning in 1970, data exclude births to nonresidents of the United States. Based on estimated total live births per 1,000 population for the specified group. Based on a 50-percent sample of births for 1951-1954, 1956-1966, and 1968-1971; on a 20- to 50-percent sample for 1967; and on a 100 percent sample for selected states and a 50 percent sample for all other states for 1972-1984. Prior to 1960, births adjusted for underregistration; thereafter, registered live births. Rates by race are by race of child before 1980 and by race of mother from 1980 onwards.

$\backslash 2$ Denotes first year for which figures include Alaska and Hawaii.

$\backslash 3$ Figures by race exclude New Jersey. That state did not require reporting of race.

$\backslash 4$ Beginning in 1997, rates for women aged 45-49 are computed by relating births to women aged $45-54$ to women aged 45-49.

Source: White population, total fertility rate, 1800-1930: Coale and Zelnik [1963], p. 36. Black population, total fertility rate: Coale and Rives [1973], p. 26. Numbers for 1890 to 1930 are arithmetic averages for the two quinquennia surrounding the year. For 1905/10, total fertility rates and age-specific birth rates are from Haines [1989], Table 1. For 1933-1939, total fertility rates and age-specific birth rates are from Linder and Grove [1947], Table 46. The rates are adjusted upward on the basis of the annual adjustments implied in U.S. Public Health Service [1999a], Tables 11 and 1-2. 1940-1959: U.S. Public Health Service [1970], Table 1-1. 1960-1997: U.S. Public Health Service [1999a], Table 1-9; [2000a], Table 4. 
Table 6. Ratio of Total Fertility Rates to White Total Fertility Rates. By Race. United States, 1850 to 1998.

\begin{tabular}{|c|c|c|c|c|c|}
\hline \multirow[b]{2}{*}{ Year } & \multicolumn{2}{|c|}{ RATIO TO WHITE } & \multirow{2}{*}{\multicolumn{2}{|c|}{$\begin{array}{c}\text { Amerin- Asian \& } \\
\text { dian Pacific } \\
\text { Islander }\end{array}$}} & \multirow[b]{2}{*}{$\begin{array}{c}\text { Hispanic- } \\
\text { Origin }\end{array}$} \\
\hline & All Other & Black & & & \\
\hline $1850 / 59$ & & 1.458 & & & \\
\hline $1860 / 69$ & & 1.455 & & & \\
\hline $1870 / 79$ & & 1.690 & & & \\
\hline $1880 / 84$ & & 1.712 & & & \\
\hline 1890 & & 1.695 & & & \\
\hline 1900 & & 1.576 & & & \\
\hline $1905 / 10$ & & 1.264 & & & \\
\hline 1910 & & 1.348 & & & \\
\hline 1920 & & 1.148 & & & \\
\hline 1930 & & 1.216 & & & \\
\hline 1933 & 1.400 & & & & \\
\hline 1934 & 1.426 & & & & \\
\hline 1935 & 1.257 & & & & \\
\hline 1936 & 1.248 & & & & \\
\hline 1937 & 1.278 & & & & \\
\hline 1938 & 1.260 & & & & \\
\hline 1939 & 1.286 & & & & \\
\hline 1940 & 1.288 & 1.288 & & & \\
\hline 1941 & 1.270 & & & & \\
\hline 1942 & 1.173 & & & & \\
\hline 1943 & 1.174 & & & & \\
\hline 1944 & 1.230 & & & & \\
\hline 1945 & 1.246 & & & & \\
\hline 1946 & 1.116 & & & & \\
\hline 1947 & 1.107 & & & & \\
\hline 1948 & 1.238 & & & & \\
\hline 1949 & 1.281 & & & & \\
\hline 1950 & 1.319 & 1.320 & & & \\
\hline 1951 & 1.296 & & & & \\
\hline 1952 & 1.276 & & & & \\
\hline 1953 & 1.296 & & & & \\
\hline 1954 & 1.310 & & & & \\
\hline 1955 & 1.320 & & & & \\
\hline 1956 & 1.334 & & & & \\
\hline 1957 & 1.324 & & & & \\
\hline 1958 & 1.328 & & & & \\
\hline 1959 & 1.297 & & & & \\
\hline 1960 & 1.280 & 1.286 & & & \\
\hline 1961 & 1.286 & & & & \\
\hline 1962 & 1.299 & & & & \\
\hline 1963 & 1.316 & & & & \\
\hline 1964 & 1.328 & 1.350 & & & \\
\hline 1965 & 1.368 & 1.375 & & & \\
\hline 1966 & 1.357 & 1.362 & & & \\
\hline 1967 & 1.348 & 1.353 & & & \\
\hline 1968 & 1.314 & 1.310 & & & \\
\hline 1969 & 1.297 & 1.289 & & & \\
\hline 1970 & 1.286 & 1.300 & & & \\
\hline
\end{tabular}


Table 6 (cont.)

RATIO TO WHITE

\begin{tabular}{|c|c|c|c|c|c|}
\hline Year & All Other & Black & $\begin{array}{l}\text { Amerin- } \\
\text { dian }\end{array}$ & $\begin{array}{l}\text { Asian \& } \\
\text { Pacific } \\
\text { Islander }\end{array}$ & $\begin{array}{c}\text { Hispanic } \\
\text { Origin }\end{array}$ \\
\hline 1971 & 1.351 & 1.343 & & & \\
\hline 1972 & 1.378 & 1.364 & & & \\
\hline 1973 & 1.370 & 1.352 & & & \\
\hline 1974 & 1.337 & 1.315 & & & \\
\hline 1975 & 1.350 & 1.330 & & & \\
\hline 1976 & 1.345 & 1.324 & & & \\
\hline 1977 & 1.338 & 1.322 & & & \\
\hline 1978 & 1.358 & 1.330 & & & \\
\hline 1979 & 1.346 & 1.319 & & & \\
\hline 1980 & 1.240 & 1.228 & 1.220 & 1.102 & \\
\hline 1981 & 1.221 & 1.211 & 1.196 & 1.130 & \\
\hline 1982 & 1.207 & 1.192 & 1.252 & 1.141 & \\
\hline 1983 & 1.197 & 1.187 & 1.253 & 1.117 & \\
\hline 1984 & 1.189 & 1.184 & 1.222 & 1.082 & \\
\hline 1985 & 1.179 & 1.180 & 1.191 & 1.055 & \\
\hline 1986 & 1.191 & 1.202 & 1.172 & 1.034 & \\
\hline 1987 & 1.202 & 1.218 & 1.163 & 1.045 & \\
\hline 1988 & 1.220 & 1.238 & 1.160 & 1.068 & \\
\hline 1989 & 1.222 & 1.260 & 1.164 & 1.009 & 1.043 \\
\hline 1990 & 1.197 & 1.238 & 1.090 & 1.000 & 1.039 \\
\hline 1991 & 1.194 & 1.243 & 1.087 & 0.980 & 1.039 \\
\hline 1992 & 1.175 & 1.225 & 1.099 & 0.974 & 1.036 \\
\hline 1993 & 1.157 & 1.203 & 1.080 & 0.977 & 1.032 \\
\hline 1994 & 1.159 & 1.159 & 1.048 & 0.979 & 1.026 \\
\hline 1995 & 1.094 & 1.094 & 1.022 & 0.967 & 1.015 \\
\hline 1996 & 1.072 & 1.069 & 1.012 & 0.951 & 1.011 \\
\hline 1997 & & 1.072 & 1.019 & 0.958 & 1.012 \\
\hline 1998 & & 1.064 & 1.024 & 0.915 & 1.009 \\
\hline
\end{tabular}

Source: Table 5 . 
Table 7. Neonatal, Infant, and Maternal Mortality Rates by Race. United States, 1850-1998. \1

\begin{tabular}{|c|c|c|c|c|c|c|c|c|c|}
\hline \multirow[b]{2}{*}{ Year } & \multicolumn{4}{|c|}{$\begin{array}{l}\text { Neonatal mortality rate } \\
\text { (per 1,000 live births) }\end{array}$} & \multicolumn{5}{|c|}{$\begin{array}{l}\text { Infant mortality rate } \\
\text { (per } 1,000 \text { live births) }\end{array}$} \\
\hline & Total & White & All Other & Black & Total & White & All Other & = Black & Hispanic \\
\hline 1850 & ----- & ----- & ----- & ----- & 228.9 & 216.8 & ----- & 340.0 & ----- \\
\hline 1860 & ----- & ----- & ----- & ----- & 196.7 & 181.3 & ----- & ----- & ----- \\
\hline 1870 & ----- & ----- & ----- & ----- & 184.5 & 175.6 & ----- & ----- & ----- \\
\hline 1880 & ----- & ----- & ----- & ----- & 225.1 & 214.8 & ----- & ----- & ----- \\
\hline 1890 & ----- & ----- & ----- & ----- & 160.4 & 150.6 & ----- & ----- & ----- \\
\hline 1900 & ----- & ----- & ----- & ----- & 129.0 & 119.8 & ----- & 170.3 & ----- \\
\hline 1910 & ----- & ----- & ----- & ----- & 104.2 & 96.5 & ----- & 142.6 & ----- \\
\hline 1915 & 44.4 & ----- & ----- & ----- & 99.9 & 98.6 & 181.2 & ----- & ----- \\
\hline 1916 & 44.1 & 43.5 & 68.9 & 68.9 & 101.0 & 99.0 & 184.9 & 184.3 & ----- \\
\hline 1917 & 43.4 & 42.6 & 58.0 & ----- & 93.8 & 90.5 & 150.7 & ----- & ----- \\
\hline 1918 & 44.2 & 43.3 & 60.5 & 60.9 & 100.9 & 97.4 & 161.2 & 162.5 & ----- \\
\hline 1919 & 41.5 & 40.3 & 55.2 & 58.6 & 86.6 & 83.0 & 130.5 & 134.3 & ----- \\
\hline 1920 & 41.5 & 40.4 & 55.0 & 56.5 & 85.8 & 82.1 & 131.7 & 135.6 & ----- \\
\hline 1921 & 39.7 & 38.7 & 50.3 & 51.3 & 75.6 & 72.5 & 108.5 & 110.7 & ----- \\
\hline 1922 & 39.7 & 38.8 & 49.9 & 50.7 & 76.2 & 73.2 & 110.0 & 111.6 & ----- \\
\hline 1923 & 39.5 & 38.6 & 49.9 & 51.4 & 77.1 & 73.5 & 117.4 & 119.9 & ----- \\
\hline 1924 & 38.6 & 37.4 & 51.2 & 51.8 & 70.8 & 66.8 & 112.9 & 114.1 & ----- \\
\hline 1925 & 37.8 & 36.8 & 49.5 & 50.3 & 71.7 & 68.3 & 110.8 & 112.0 & ----- \\
\hline 1926 & 37.9 & 37.1 & 48.0 & 48.3 & 73.3 & 70.0 & 111.8 & 112.1 & ----- \\
\hline 1927 & 36.1 & 35.0 & 46.1 & 46.3 & 64.6 & 60.6 & 100.1 & 99.9 & ----- \\
\hline 1928 & 37.2 & 35.7 & 48.8 & 49.1 & 68.7 & 64.0 & 106.2 & 105.9 & ----- \\
\hline 1929 & 36.9 & 35.6 & 47.3 & 47.5 & 67.6 & 63.2 & 102.2 & 101.5 & ----- \\
\hline 1930 & 35.7 & 34.2 & 47.4 & 47.6 & 64.6 & 60.1 & 99.9 & 99.5 & ----- \\
\hline 1931 & 34.6 & 33.2 & 45.2 & 45.4 & 61.6 & 57.4 & 93.1 & 92.7 & ----- \\
\hline 1932 & 33.5 & 32.0 & 43.7 & 44.4 & 57.6 & 53.3 & 86.2 & 84.1 & ----- \\
\hline 1933 & 34.0 & 32.1 & 45.8 & 45.7 & 58.1 & 52.8 & 91.3 & 85.4 & ----- \\
\hline 1934 & 34.1 & 32.3 & 45.3 & 46.0 & 60.1 & 54.5 & 94.4 & 91.0 & ----- \\
\hline 1935 & 32.4 & 31.0 & 42.7 & 42.7 & 55.7 & 51.9 & 83.2 & 81.9 & ----- \\
\hline 1936 & 32.6 & 31.0 & 43.9 & 43.8 & 57.1 & 52.9 & 87.6 & 86.1 & ----- \\
\hline 1937 & 31.3 & 29.7 & 42.1 & 42.2 & 54.4 & 50.3 & 83.2 & 82.0 & ----- \\
\hline 1938 & 29.6 & 28.3 & 39.1 & 39.2 & 51.0 & 47.1 & 79.1 & 77.9 & ----- \\
\hline 1939 & 29.3 & 27.8 & 39.6 & 39.7 & 48.0 & 44.3 & 74.2 & 73.2 & ----- \\
\hline 1940 & 28.8 & 27.2 & 39.7 & 39.9 & 47.0 & 43.2 & 73.8 & 72.9 & ----- \\
\hline 1941 & 27.7 & 26.1 & 39.0 & 39.3 & 45.3 & 41.2 & 74.8 & 74.1 & ----- \\
\hline 1942 & 25.7 & 24.5 & 34.6 & 34.9 & 40.4 & 37.3 & 64.6 & 64.2 & ----- \\
\hline 1943 & 24.7 & 23.7 & 32.9 & 33.1 & 40.4 & 37.5 & 62.5 & 61.5 & ----- \\
\hline 1944 & 24.7 & 23.6 & 32.5 & 32.7 & 39.8 & 36.9 & 60.3 & 59.3 & ----- \\
\hline 1945 & 24.3 & 23.3 & 32.0 & 32.2 & 38.3 & 35.6 & 57.0 & 56.2 & ----- \\
\hline 1946 & 24.0 & 23.1 & 31.5 & 31.7 & 33.8 & 31.8 & 49.5 & 48.8 & ----- \\
\hline 1947 & 22.8 & 21.7 & 31.0 & 31.1 & 32.2 & 30.1 & 48.5 & 47.7 & ----- \\
\hline 1948 & 22.2 & 21.2 & 29.1 & 29.3 & 32.0 & 29.9 & 46.5 & 45.7 & ----- \\
\hline 1949 & 21.4 & 20.3 & 28.6 & 28.8 & 31.3 & 28.9 & 47.3 & 46.8 & ----- \\
\hline 1950 & 20.5 & 19.4 & 27.5 & 27.8 & 29.2 & 26.8 & 44.5 & 43.9 & ----- \\
\hline 1951 & 20.0 & 18.9 & 27.3 & 27.6 & 28.4 & 25.8 & 44.8 & 44.3 & ----- \\
\hline 1952 & 19.8 & 18.5 & 28.0 & 28.5 & 28.4 & 25.5 & 47.0 & 46.9 & ----- \\
\hline 1953 & 19.6 & 18.3 & 27.4 & 27.8 & 27.8 & 25.0 & 44.7 & 44.5 & ----- \\
\hline 1954 & 19.1 & 17.8 & 27.0 & 27.5 & 26.6 & 23.9 & 42.9 & 42.9 & ----- \\
\hline 1955 & 19.1 & 17.7 & 27.2 & 27.8 & 26.4 & 23.6 & 42.8 & 43.1 & ----- \\
\hline
\end{tabular}


Table 7 (cont.)

\begin{tabular}{|c|c|c|c|c|c|c|c|c|c|c|c|}
\hline & & \multicolumn{5}{|c|}{$\begin{array}{l}\text { Neonatal mortality rate } \\
\text { (per } 1,000 \text { live births) }\end{array}$} & \multicolumn{5}{|c|}{$\begin{array}{l}\text { Infant mortality rate } \\
\text { (per } 1,000 \text { live births) }\end{array}$} \\
\hline Year & & Total & White & All & other & Black & Total & White & All other & Black & Hispanic \\
\hline $\begin{array}{l}1956 \\
1957\end{array}$ & & $\begin{array}{l}18.9 \\
19.1\end{array}$ & $\begin{array}{r}17.5 \\
17.5\end{array}$ & & $\begin{array}{l}27.0 \\
27.8\end{array}$ & $\begin{array}{l}27.6 \\
28.5\end{array}$ & $\begin{array}{l}26.0 \\
26.3\end{array}$ & $\begin{array}{l}23.2 \\
23.3\end{array}$ & $\begin{array}{l}42.1 \\
43.7\end{array}$ & $\begin{array}{l}42.4 \\
44.2\end{array}$ & $\begin{array}{l}----- \\
-----\end{array}$ \\
\hline 1958 & & $\begin{array}{l}19.1 \\
19.5\end{array}$ & 17.8 & & 29.0 & $\begin{array}{l}20.0 \\
29.7\end{array}$ & $\begin{array}{l}20.3 \\
27.1\end{array}$ & 23.8 & 45.7 & 46.3 & ----- \\
\hline 1959 & 13 & 19.0 & 17.5 & & 27.7 & 28.4 & 26.4 & 23.2 & 44.0 & 44.8 & ----- \\
\hline 1960 & * & 18.7 & 17.2 & & 26.9 & 27.8 & 26.0 & 22.9 & 43.2 & 44.3 & ----- \\
\hline 1961 & & 18.4 & 16.9 & & 26.2 & 27.1 & 25.3 & 22.4 & 40.7 & 41.8 & ----- \\
\hline 1962 & $\backslash 2$ & 18.3 & 16.9 & & 26.1 & 27.1 & 25.3 & 22.3 & 41.4 & 42.6 & ----- \\
\hline 1963 & $\backslash 2$ & 18.2 & 16.7 & & 26.1 & 27.0 & 25.2 & 22.2 & 41.5 & 42.8 & ----- \\
\hline 1964 & & 17.9 & 16.2 & & 26.5 & 27.5 & 24.8 & 21.6 & 41.1 & 42.3 & ----- \\
\hline 1965 & & 17.7 & 16.1 & & 25.4 & 26.5 & 24.7 & 21.5 & 40.3 & 41.7 & ----- \\
\hline 1966 & & 17.2 & 15.6 & & 24.8 & 25.9 & 23.7 & 20.6 & 38.8 & 40.2 & ----- \\
\hline 1967 & & 16.5 & 15.0 & & 23.8 & 25.0 & 22.4 & 19.7 & 35.9 & 37.5 & ----- \\
\hline 1968 & & 16.1 & 14.7 & & 23.0 & 24.3 & 21.8 & 19.2 & 34.5 & 36.2 & ----- \\
\hline 1969 & & 15.6 & 14.2 & & 22.5 & 23.9 & 20.9 & 18.4 & 32.9 & 34.8 & ----- \\
\hline 1970 & & 15.1 & 13.8 & & 21.4 & 22.6 & 20.0 & 17.8 & 30.9 & 32.6 & ----- \\
\hline 1971 & & 14.2 & 13.0 & & 19.6 & 21.0 & 19.1 & 17.1 & 28.5 & 30.3 & ----- \\
\hline 1972 & & 13.6 & 12.4 & & 19.2 & 20.7 & 18.5 & 16.4 & 27.7 & 29.6 & ----- \\
\hline 1973 & & 13.0 & 11.8 & & 17.9 & 19.3 & 17.7 & 15.8 & 26.2 & 28.1 & ----- \\
\hline 1974 & & 12.3 & 11.1 & & 17.2 & 18.7 & 16.7 & 14.8 & 24.9 & 26.8 & ----- \\
\hline 1975 & & 11.6 & 10.4 & & 16.8 & 18.3 & 16.1 & 14.2 & 24.2 & 26.2 & ----- \\
\hline 1976 & & 10.9 & 9.7 & & 16.3 & 17.9 & 15.2 & 13.3 & 23.5 & 25.5 & ----- \\
\hline 1977 & & 9.9 & 8.7 & & 14.7 & 16.1 & 14.1 & 12.3 & 21.7 & 23.6 & ----- \\
\hline 1978 & & 9.5 & 8.4 & & 14.0 & 15.5 & 13.8 & 12.0 & 21.1 & 23.1 & ----- \\
\hline 1979 & & 8.9 & 7.9 & & 12.9 & 14.3 & 13.1 & 11.4 & 19.8 & 21.8 & ----- \\
\hline 1980 & & 8.5 & 7.4 & & 13.2 & 14.6 & 12.6 & 10.9 & 20.2 & 22.2 & ----- \\
\hline 1981 & & 8.0 & 7.0 & & 12.5 & 14.0 & 11.9 & 10.3 & 18.8 & 20.8 & ----- \\
\hline 1982 & & 7.7 & 6.7 & & 12.0 & 13.6 & 11.5 & 9.9 & 18.3 & 20.5 & ----- \\
\hline 1983 & & 7.3 & 6.3 & & 11.4 & 12.9 & 11.2 & 9.6 & 17.8 & 20.0 & ----- \\
\hline 1984 & & 7.0 & 6.1 & & 10.9 & 12.3 & 10.8 & 9.3 & 17.1 & 19.2 & ----- \\
\hline 1985 & & 7.0 & 6.0 & & 11.0 & 12.6 & 10.6 & 9.2 & 16.8 & 19.0 & ----- \\
\hline 1986 & & 6.7 & 5.7 & & 10.8 & 12.3 & 10.4 & 8.8 & 16.7 & 18.9 & ----- \\
\hline 1987 & & 6.5 & 5.4 & & 10.7 & 12.3 & 10.1 & 8.5 & 16.5 & 18.8 & ----- \\
\hline 1988 & & 6.3 & 5.3 & & 10.3 & 12.1 & 10.0 & 8.4 & 16.1 & 18.5 & ----- \\
\hline 1989 & & 6.2 & 5.1 & & 10.3 & 11.9 & 9.8 & 8.1 & 16.3 & 18.6 & 9.8 \\
\hline 1990 & & 5.8 & 4.8 & & 9.9 & 11.6 & 9.2 & 7.6 & 15.5 & 18.0 & 9.1 \\
\hline 1991 & & 5.6 & 4.5 & & 9.5 & 11.2 & 8.9 & 7.3 & 15.1 & 17.6 & 8.9 \\
\hline 1992 & & 5.4 & 4.3 & & 9.2 & 10.8 & 8.5 & 6.9 & 14.4 & 16.8 & 8.5 \\
\hline 1993 & & 5.3 & 4.3 & & 9.0 & 10.7 & 8.4 & 6.8 & 14.1 & 16.5 & 8.4 \\
\hline 1994 & & 5.1 & 4.2 & & 8.6 & 10.2 & 8.0 & 6.6 & 13.5 & 15.8 & 8.0 \\
\hline 1995 & & 4.9 & 4.1 & & 8.1 & 9.8 & 7.6 & 6.3 & 12.6 & 15.1 & 7.6 \\
\hline 1996 & & 4.8 & 4.0 & & 7.9 & 9.6 & 7.3 & 6.1 & 12.2 & 14.7 & 7.3 \\
\hline 1997 & & 4.8 & 4.0 & & 7.7 & 9.4 & 7.2 & 6.0 & 11.8 & 14.2 & 7.2 \\
\hline 1998 & & 4.8 & 4.0 & & 7.9 & 9.5 & 7.2 & 6.0 & 11.9 & 14.3 & 7.2 \\
\hline
\end{tabular}


Table 7 (cont.)

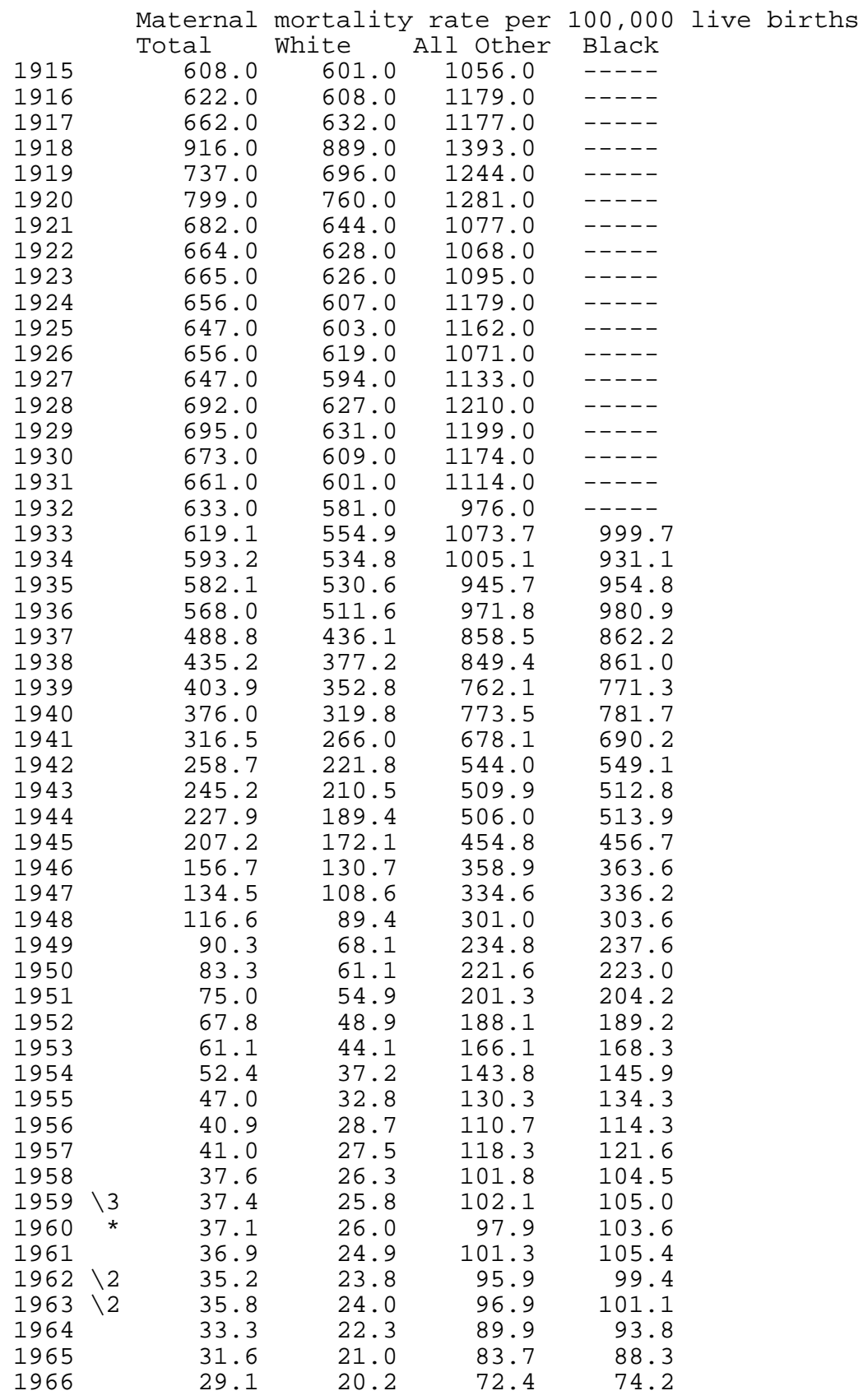


Table 7 (cont.)

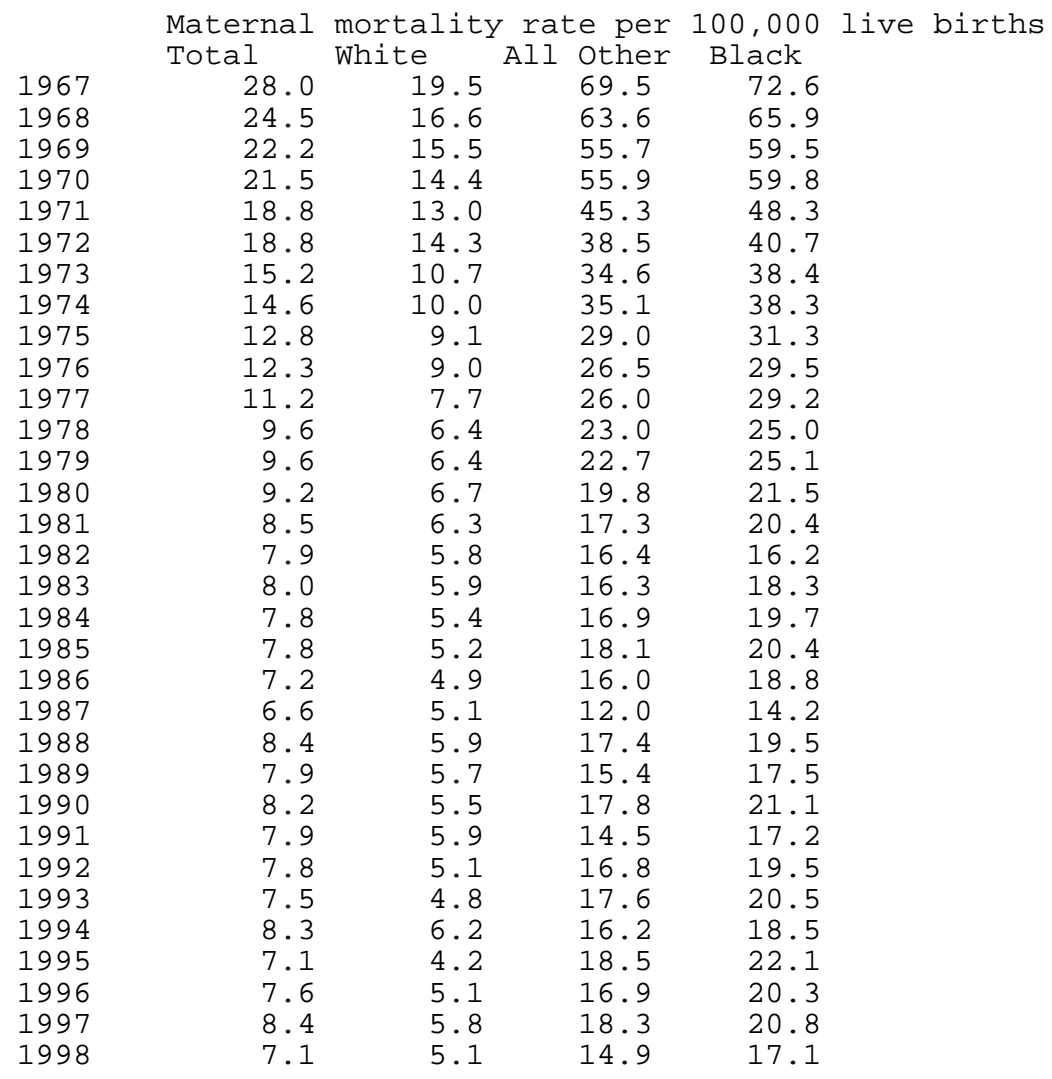

$\backslash 1$ The neonatal mortality rate is deaths of infants aged 0-27 days per 1,000 live births. The infant mortality rate is deaths in the first year of life per 1,000 live births. the maternal mortality rate is deaths related to childbirth per 100,000 live births. Prior to 1980, race for live births is the race of the child. From 1980 onwards, race for live births is the race of the mother. For 1915 to 1932, for the current Birth Registration Area only.

12 Includes Alaska.

13 Denotes first year for which figures includes Alaska and Hawaii.

$\backslash 4$ Figures by race excludes New Jersey. The state did not require reporting of race.

Source: 1915-1992: U.S. Public Health Service [1996], Table 2-2. 1993-1998: U.S. Public Health Service [2000b], Table 27. For the total and white populations for 1850-1910 and for the black population for 1900 and 1910, Haines [1998]. For the black population in 1850, Steckel [1986]. 
Table 8. Expectation of Life (in Years) at Birth, by Race and Sex: 1850 to 1998.

\begin{tabular}{|c|c|c|c|c|c|c|c|c|c|c|c|c|c|}
\hline Year & & $\begin{array}{l}\text { Total } \\
\text { Both Sexes }\end{array}$ & Male & Female & $\begin{array}{l}\text { White } \\
\text { Both Sexes }\end{array}$ & Male & Female & $\begin{array}{l}\text { Negro and } \\
\text { Both Sexes }\end{array}$ & $\begin{array}{l}\text { other } \\
\text { Male }\end{array}$ & Female & $\begin{array}{l}\text { Black } \\
\text { Both Sexes }\end{array}$ & Male & Female \\
\hline 1850 & & 38.3 & 37.2 & 39.4 & 39.5 & 38.4 & 40.6 & ----- & ----- & ----- & ----- & ----- & ----- \\
\hline 1860 & & 41.8 & 41.6 & 42.2 & 43.6 & 43.2 & 44.1 & ----- & ----- & ----- & ----- & ----- & ----- \\
\hline 1870 & & 44.0 & 43.0 & 44.9 & 45.2 & 44.1 & 46.4 & ----- & ----- & ----- & ----- & ----- & ----- \\
\hline 1880 & & 39.4 & 39.7 & 39.1 & 40.5 & 40.4 & 40.6 & ----- & ----- & ----- & ----- & ----- & ----- \\
\hline 1890 & & 45.2 & 44.8 & 45.6 & 46.8 & 46.0 & 47.4 & ----- & ----- & ----- & ----- & ----- & ----- \\
\hline 1900 & & 47.8 & 47.1 & 48.4 & 49.6 & 48.5 & 50.7 & ----- & ----- & ----- & 41.8 & 40.4 & 43.3 \\
\hline 1910 & & 53.1 & 51.5 & 54.7 & 54.6 & 53.0 & 56.0 & ----- & ----- & ----- & 46.2 & 44.7 & 47.7 \\
\hline 1900 & $\backslash 1$ & 47.3 & 46.3 & 48.3 & 47.6 & 46.6 & 48.7 & 33.0 & 32.5 & 33.5 & ----- & ----- & ----- \\
\hline 1901 & & 49.1 & 47.6 & 50.6 & 49.4 & 48.0 & 51.0 & 33.7 & 32.2 & 35.3 & ----- & ----- & ----- \\
\hline 1902 & & 51.5 & 49.8 & 53.4 & 51.9 & 50.2 & 53.8 & 34.6 & 32.9 & 36.4 & ----- & ----- & ----- \\
\hline 1903 & & 50.5 & 49.1 & 52.0 & 50.9 & 49.5 & 52.5 & 33.1 & 31.7 & 34.6 & ----- & ----- & ----- \\
\hline 1904 & & 47.6 & 46.2 & 49.1 & 48.0 & 46.6 & 49.5 & 30.8 & 29.1 & 32.7 & ----- & ----- & ----- \\
\hline 1905 & & 48.7 & 47.3 & 50.2 & 49.1 & 47.6 & 50.6 & 31.3 & 29.6 & 33.1 & ----- & ----- & ----- \\
\hline 1906 & & 48.7 & 46.9 & 50.8 & 49.3 & 47.3 & 51.4 & 32.9 & 31.8 & 33.9 & ----- & ----- & ----- \\
\hline 1907 & & 47.6 & 45.6 & 49.9 & 48.1 & 46.0 & 50.4 & 32.5 & 31.1 & 34.0 & ----- & ----- & ----- \\
\hline 1908 & & 51.1 & 49.5 & 52.8 & 51.5 & 49.9 & 53.3 & 34.9 & 33.8 & 36.0 & ----- & ----- & ----- \\
\hline 1909 & & 52.1 & 50.5 & 53.8 & 52.5 & 50.9 & 54.2 & 35.7 & 34.2 & 37.3 & ----- & ----- & ----- \\
\hline 1910 & & 50.0 & 48.4 & 51.8 & 50.3 & 48.6 & 52.0 & 35.6 & 33.8 & 37.5 & ----- & ----- & ----- \\
\hline 1911 & & 52.6 & 50.9 & 54.4 & 53.0 & 51.3 & 54.9 & 36.4 & 34.6 & 38.2 & ----- & ----- & ----- \\
\hline 1912 & & 53.5 & 51.5 & 55.9 & 53.9 & 51.9 & 56.2 & 37.9 & 35.9 & 40.0 & ----- & ----- & ----- \\
\hline 1913 & & 52.5 & 50.3 & 55.0 & 53.0 & 50.8 & 55.7 & 38.4 & 36.7 & 40.3 & ----- & ----- & ----- \\
\hline 1914 & & 54.2 & 52.0 & 56.8 & 54.9 & 52.7 & 57.5 & 38.9 & 37.1 & 40.8 & ----- & ----- & ----- \\
\hline 1915 & & 54.5 & 52.5 & 56.8 & 55.1 & 53.1 & 57.5 & 38.9 & 37.5 & 40.5 & ----- & ----- & ----- \\
\hline 1916 & & 51.7 & 49.6 & 54.3 & 52.5 & 50.2 & 55.2 & 41.3 & 39.6 & 43.1 & ----- & ----- & ----- \\
\hline 1917 & & 50.9 & 48.4 & 54.0 & 52.0 & 49.3 & 55.3 & 38.8 & 37.0 & 40.8 & ----- & ----- & ----- \\
\hline 1918 & & 39.1 & 36.6 & 42.2 & 39.8 & 37.1 & 43.2 & 31.1 & 29.9 & 32.5 & ----- & ----- & ----- \\
\hline 1919 & & 54.7 & 53.5 & 56.0 & 55.8 & 54.5 & 57.4 & 44.5 & 44.5 & 44.4 & ----- & ----- & ----- \\
\hline 1920 & & 54.1 & 53.6 & 54.6 & 54.9 & 54.4 & 55.6 & 45.3 & 45.5 & 45.2 & ----- & ----- & ----- \\
\hline 1921 & & 60.8 & 60.0 & 61.8 & 61.8 & 60.8 & 62.9 & 51.5 & 51.6 & 51.3 & ----- & ----- & ----- \\
\hline 1922 & & 59.6 & 58.4 & 61.0 & 60.4 & 59.1 & 61.9 & 52.4 & 51.8 & 53.0 & ----- & ----- & ----- \\
\hline 1923 & & 57.2 & 56.1 & 58.5 & 58.3 & 57.1 & 59.6 & 48.3 & 47.7 & 48.9 & ----- & ----- & ----- \\
\hline 1924 & & 59.7 & 58.1 & 61.5 & 61.4 & 59.8 & 63.4 & 46.6 & 45.5 & 47.8 & ----- & ----- & ----- \\
\hline 1925 & & 59.0 & 57.6 & 60.6 & 60.7 & 59.3 & 62.4 & 45.7 & 44.9 & 46.7 & ----- & ----- & ----- \\
\hline 1926 & & 56.7 & 55.5 & 58.0 & 58.2 & 57.0 & 59.6 & 44.6 & 43.7 & 45.6 & ----- & ----- & ----- \\
\hline
\end{tabular}


Table 8 (cont.)

\begin{tabular}{|c|c|c|c|c|c|c|c|c|c|c|c|c|c|}
\hline Year & & $\begin{array}{l}\text { Total } \\
\text { Both Sexes }\end{array}$ & Male & Female & $\begin{array}{l}\text { White } \\
\text { Both Sexes }\end{array}$ & Male & Female & $\begin{array}{l}\text { Negro and } \\
\text { Both Sexes }\end{array}$ & $\begin{array}{l}\text { ther } \\
\text { Male }\end{array}$ & Female & $\begin{array}{l}\text { Black } \\
\text { Both Sexes }\end{array}$ & Male & Female \\
\hline 1927 & & 60.4 & 59.0 & 62.1 & 62.0 & 60.5 & 63.9 & 48.2 & 47.6 & 48.9 & ----- & ----- & ---- \\
\hline 1928 & & 56.8 & 55.6 & 58.3 & 58.4 & 57.0 & 60.0 & 46.3 & 45.6 & 47.0 & ----- & ----- & ----- \\
\hline 1929 & & 57.1 & 55.8 & 58.7 & 58.6 & 57.2 & 60.3 & 46.7 & 45.7 & 47.8 & ----- & ----- & ----- \\
\hline 1930 & & 59.7 & 58.1 & 61.6 & 61.4 & 59.7 & 63.5 & 48.1 & 47.3 & 49.2 & ----- & ----- & ----- \\
\hline 1931 & & 61.1 & 59.4 & 63.1 & 62.6 & 60.8 & 64.7 & 50.4 & 49.5 & 51.5 & ----- & ----- & ----- \\
\hline 1932 & & 62.1 & 61.0 & 63.5 & 63.2 & 62.0 & 64.5 & 53.7 & 52.8 & 54.6 & ----- & ----- & ----- \\
\hline 1933 & & 63.3 & 61.7 & 65.1 & 64.3 & 62.7 & 66.3 & 54.7 & 53.5 & 56.0 & ----- & ----- & ----- \\
\hline 1934 & & 61.1 & 59.3 & 63.3 & 62.4 & 50.6 & 64.6 & 51.8 & 50.2 & 53.7 & ----- & ----- & ----- \\
\hline 1935 & & 61.7 & 59.9 & 63.9 & 62.9 & 61.0 & 65.0 & 53.1 & 51.3 & 55.2 & ----- & ----- & ----- \\
\hline 1936 & & 58.5 & 56.6 & 60.6 & 59.8 & 58.0 & 61.9 & 49.0 & 47.0 & 51.4 & ----- & ----- & ----- \\
\hline 1937 & & 60.0 & 58.0 & 62.4 & 61.4 & 59.3 & 63.8 & 50.3 & 48.3 & 52.5 & ----- & ----- & ----- \\
\hline 1938 & & 63.5 & 61.9 & 65.3 & 65.0 & 63.2 & 66.8 & 52.9 & 51.7 & 54.3 & ----- & ----- & ----- \\
\hline 1939 & & 63.7 & 62.1 & 65.4 & 64.9 & 63.3 & 66.6 & 54.5 & 53.2 & 56.0 & ----- & ----- & ----- \\
\hline 1940 & & 62.9 & 60.8 & 65.2 & 64.2 & 62.1 & 66.6 & 53.1 & 51.5 & 54.9 & ----- & ----- & ----- \\
\hline 1941 & & 64.8 & 63.1 & 66.8 & 66.2 & 64.4 & 68.5 & 53.8 & 52.5 & 55.3 & ----- & ----- & ----- \\
\hline 1942 & & 66.2 & 64.7 & 67.9 & 67.3 & 65.9 & 69.4 & 56.6 & 55.4 & 58.2 & ----- & ----- & ----- \\
\hline 1943 & & 63.3 & 62.4 & 64.4 & 64.2 & 63.2 & 65.7 & 55.6 & 55.4 & 56.1 & ----- & ----- & ----- \\
\hline 1944 & & 65.2 & 63.6 & 66.8 & 66.2 & 64.5 & 68.4 & 56.6 & 55.8 & 57.7 & ----- & ----- & ----- \\
\hline 1945 & & 65.9 & 63.6 & 67.9 & 66.8 & 64.4 & 69.5 & 57.7 & 56.1 & 59.6 & ----- & ----- & ----- \\
\hline 1946 & & 66.7 & 64.4 & 69.4 & 67.5 & 65.1 & 70.3 & 59.1 & 57.5 & 61.0 & ----- & ----- & ----- \\
\hline 1947 & & 66.8 & 64.4 & 69.7 & 67.6 & 65.2 & 70.5 & 59.7 & 57.9 & 61.9 & ----- & ----- & ----- \\
\hline 1948 & & 67.2 & 64.6 & 69.9 & 68.0 & 65.5 & 71.0 & 60.0 & 58.1 & 62.5 & ----- & ----- & ----- \\
\hline 1949 & & 68.0 & 65.2 & 70.7 & 68.8 & 66.2 & 71.9 & 60.6 & 58.9 & 62.7 & ----- & ----- & ----- \\
\hline 1950 & & 68.2 & 65.6 & 71.1 & 69.1 & 66.5 & 72.2 & 60.8 & 59.1 & 62.9 & ----- & ----- & ----- \\
\hline 1951 & & 68.4 & 65.6 & 71.4 & 69.3 & 66.5 & 72.4 & 61.2 & 59.2 & 63.4 & ----- & ----- & ----- \\
\hline 1952 & & 68.6 & 65.8 & 71.6 & 69.5 & 66.6 & 72.6 & 61.4 & 59.1 & 63.8 & ----- & ----- & ----- \\
\hline 1953 & & 68.8 & 66.0 & 72.0 & 69.7 & 66.8 & 73.0 & 62.0 & 59.7 & 64.5 & ----- & ----- & ----- \\
\hline 1954 & & 69.6 & 66.7 & 72.8 & 70.5 & 67.5 & 73.7 & 63.4 & 61.1 & 65.9 & ----- & ----- & ----- \\
\hline 1955 & & 69.6 & 66.7 & 72.8 & 70.5 & 67.4 & 73.7 & 63.7 & 61.4 & 66.1 & ----- & ----- & ----- \\
\hline 1956 & & 69.7 & 66.7 & 72.9 & 70.5 & 67.5 & 73.9 & 63.6 & 61.3 & 66.1 & ----- & ----- & ----- \\
\hline 1957 & & 69.5 & 66.4 & 72.7 & 70.3 & 67.7 & 73.7 & 63.0 & 60.7 & 65.5 & ----- & ----- & ----- \\
\hline 1958 & & 69.6 & 66.6 & 72.9 & 70.5 & 67.4 & 73.9 & 63.4 & 61.0 & 65.8 & ----- & ----- & ----- \\
\hline 1959 & $\backslash 2$ & 69.9 & 66.8 & 73.2 & 70.7 & 67.5 & 74.2 & 63.9 & 61.3 & 66.5 & ----- & ----- & ----- \\
\hline 1960 & 13 & 69.7 & 66.6 & 73.1 & 70.6 & 67.4 & 74.1 & 63.6 & 61.1 & 66.3 & ----- & ----- & ----- \\
\hline 1961 & & 70.2 & 67.1 & 73.6 & 71.0 & 67.8 & 74.6 & 64.5 & 62.0 & 67.1 & ----- & ----- & ---- \\
\hline
\end{tabular}


Table 8 (cont.)

\begin{tabular}{|c|c|c|c|c|c|c|c|c|c|c|c|c|c|}
\hline Year & & $\begin{array}{l}\text { Total } \\
\text { Both Sexes }\end{array}$ & Male & Female & $\begin{array}{l}\text { White } \\
\text { Both Sexes }\end{array}$ & Male & Female & $\begin{array}{l}\text { Negro and } \\
\text { Both Sexes }\end{array}$ & $\begin{array}{l}\text { other } \\
\text { Male }\end{array}$ & Female & $\begin{array}{l}\text { Black } \\
\text { Both Sexes }\end{array}$ & Male & Female \\
\hline 1962 & $\backslash 4$ & 70.1 & 66.9 & 73.5 & 70.9 & 67.7 & 74.5 & 64.2 & 61.6 & 66.9 & ----- & ----- & ----- \\
\hline 1963 & $\backslash 4$ & 69.9 & 66.6 & 73.4 & 70.8 & 67.4 & 74.4 & 63.7 & 61.0 & 66.6 & ----- & ----- & ----- \\
\hline 1964 & & 70.2 & 66.8 & 73.7 & 71.0 & 67.7 & 74.7 & 64.2 & 61.3 & 67.3 & ----- & ----- & ----- \\
\hline 1965 & & 70.2 & 66.8 & 73.8 & 71.1 & 67.6 & 74.8 & 64.3 & 61.2 & 67.6 & ----- & ----- & ----- \\
\hline 1966 & & 70.2 & 66.7 & 73.9 & 71.1 & 67.5 & 74.8 & 64.2 & 60.9 & 67.6 & ----- & ----- & ----- \\
\hline 1967 & & 70.5 & 67.0 & 74.3 & 71.4 & 67.8 & 75.2 & 64.9 & 61.4 & 68.5 & ----- & ----- & ----- \\
\hline 1968 & & 70.2 & 66.6 & 74.1 & 71.1 & 67.5 & 75.0 & 64.1 & 60.4 & 67.9 & ----- & ----- & ----- \\
\hline 1969 & & 70.5 & 66.8 & 74.4 & 71.4 & 67.7 & 75.3 & 64.5 & 60.6 & 68.6 & ----- & ----- & ----- \\
\hline 1970 & & 70.8 & 67.1 & 74.7 & 71.7 & 68.0 & 75.6 & 65.3 & 61.3 & 69.4 & 64.1 & 60.0 & 68.3 \\
\hline 1971 & & 71.1 & 67.4 & 75.0 & 72.0 & 68.3 & 75.8 & 65.6 & 61.6 & 69.8 & 64.6 & 60.5 & 68.9 \\
\hline 1972 & & 71.2 & 67.4 & 75.1 & 72.0 & 68.3 & 75.9 & 65.7 & 61.5 & 70.1 & 64.7 & 60.4 & 69.1 \\
\hline 1973 & & 71.4 & 67.6 & 75.3 & 72.2 & 68.5 & 76.1 & 66.1 & 62.0 & 70.3 & 65.0 & 60.9 & 69.3 \\
\hline 1974 & & 72.0 & 68.2 & 75.9 & 72.8 & 69.0 & 76.7 & 67.1 & 62.9 & 71.3 & 66.0 & 61.7 & 70.3 \\
\hline 1975 & & 72.6 & 68.8 & 76.6 & 73.4 & 69.5 & 77.3 & 68.0 & 63.7 & 72.4 & 66.8 & 62.4 & 71.3 \\
\hline 1976 & & 72.9 & 69.1 & 76.8 & 73.6 & 69.9 & 77.5 & 68.4 & 64.2 & 72.7 & 67.2 & 62.9 & 71.6 \\
\hline 1977 & & 73.3 & 69.5 & 77.2 & 74.0 & 70.2 & 77.9 & 68.9 & 64.7 & 73.2 & 67.7 & 63.4 & 72.0 \\
\hline 1978 & & 73.5 & 69.6 & 77.3 & 74.1 & 70.4 & 78.0 & 69.3 & 65.0 & 73.5 & 68.1 & 63.7 & 72.4 \\
\hline 1979 & & 73.9 & 70.0 & 77.8 & 74.6 & 70.8 & 78.4 & 69.8 & 65.4 & 74.1 & 68.5 & 64.0 & 72.9 \\
\hline 1980 & & 73.7 & 70.0 & 77.4 & 74.4 & 70.7 & 78.1 & 69.5 & 65.3 & 73.6 & 68.1 & 63.8 & 72.5 \\
\hline 1981 & & 74.1 & 70.4 & 77.8 & 74.8 & 71.1 & 78.4 & 70.3 & 66.2 & 74.4 & 68.9 & 64.5 & 73.2 \\
\hline 1982 & & 74.5 & 70.8 & 78.1 & 75.1 & 71.5 & 78.7 & 70.9 & 66.8 & 74.9 & 69.4 & 65.1 & 73.6 \\
\hline 1983 & & 74.6 & 71.0 & 78.1 & 75.2 & 71.6 & 78.7 & 70.9 & 67.0 & 74.7 & 69.4 & 65.2 & 73.5 \\
\hline 1984 & & 74.7 & 71.1 & 78.2 & 75.3 & 71.8 & 78.7 & 71.1 & 67.2 & 74.9 & 69.5 & 65.3 & 73.6 \\
\hline 1985 & & 74.7 & 71.1 & 78.2 & 75.3 & 71.8 & 78.7 & 71.0 & 67.0 & 74.8 & 69.3 & 65.0 & 73.4 \\
\hline 1986 & & 74.7 & 71.2 & 78.2 & 75.4 & 71.9 & 78.8 & 70.9 & 66.8 & 74.9 & 69.1 & 64.8 & 73.4 \\
\hline 1987 & & 74.9 & 71.4 & 78.3 & 75.6 & 72.1 & 78.9 & 71.0 & 66.9 & 75.0 & 69.1 & 64.7 & 73.4 \\
\hline 1988 & & 74.9 & 71.4 & 78.3 & 75.6 & 72.2 & 78.9 & 70.8 & 66.7 & 74.8 & 68.9 & 64.4 & 73.2 \\
\hline 1989 & & 75.1 & 71.7 & 78.5 & 75.9 & 72.5 & 79.2 & 70.9 & 66.7 & 74.9 & 68.8 & 64.3 & 73.3 \\
\hline 1990 & & 75.4 & 71.8 & 78.8 & 76.1 & 72.7 & 79.4 & 71.2 & 67.0 & 75.2 & 69.1 & 64.5 & 73.6 \\
\hline 1991 & & 75.5 & 72.0 & 78.9 & 76.3 & 72.9 & 79.6 & 71.5 & 67.3 & 75.5 & 69.3 & 64.6 & 73.8 \\
\hline 1992 & & 75.8 & 72.3 & 79.1 & 76.5 & 73.2 & 79.8 & 71.8 & 67.7 & 75.7 & 69.6 & 65.0 & 73.9 \\
\hline 1993 & & 75.5 & 72.2 & 78.8 & 76.3 & 73.1 & 79.5 & 71.5 & 67.3 & 75.5 & 69.2 & 64.6 & 73.7 \\
\hline 1994 & & 75.7 & 72.4 & 79.0 & 76.5 & 73.3 & 79.6 & 71.7 & 67.6 & 75.7 & 69.5 & 64.9 & 73.9 \\
\hline 1995 & & 75.8 & 72.5 & 78.9 & 76.5 & 73.4 & 79.6 & 71.9 & 67.9 & 75.7 & 69.6 & 65.2 & 73.9 \\
\hline 1996 & & 76.1 & 73.1 & 79.1 & 76.8 & 73.9 & 79.7 & 72.6 & 68.9 & 76.1 & 70.2 & 66.1 & 74.2 \\
\hline
\end{tabular}


Table 8 (cont.)

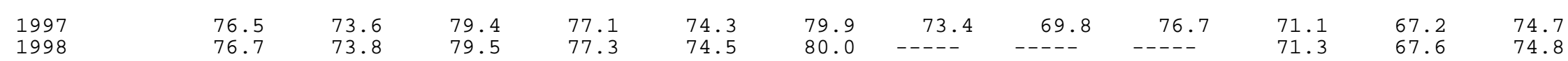

1 For 1900 to 1929 (annual data) for the death-registration area only.

12 Includes Alaska.

13 Denotes first year for which figures includes Alaska and Hawaii.

$\backslash 4$ Excludes New Jersey; State did not require reporting of race.

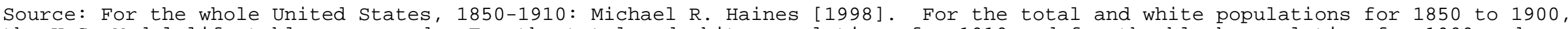
the U.S. Model life tables are used. For the total and white populations for 1910 and for the black population for 1900 and

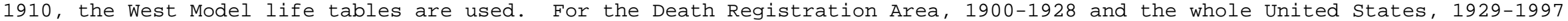

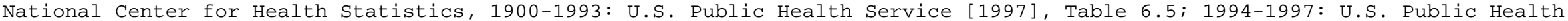

Service [1999b], Table 6. U.S. Public Health Service [2000b], Table 6. 
Table 9. Age-Adjusted Death Rates. By Sex and Race. United States, 1900-1998. \1

\begin{tabular}{|c|c|c|c|c|c|c|c|c|c|c|c|c|}
\hline & Total & Total & White & White & $\begin{array}{l}\text { All } \\
\text { Other }\end{array}$ & $\begin{array}{l}\text { All } \\
\text { Other }\end{array}$ & Black & Black & $\begin{array}{c}\text { Amerin- } \\
\text { dian }\end{array}$ & $\begin{array}{c}\text { Amerin- } \\
\text { dian }\end{array}$ & $\begin{array}{l}\text { Asian \& } \\
\text { Pac Isl }\end{array}$ & $\begin{array}{l}\text { Asian \& } \\
\text { Pac IsI }\end{array}$ \\
\hline & Male & Female & Male & Female & Male & Female & Male & Female & Male & Female & Male & Female \\
\hline 1900 & 1862.7 & 1695.2 & 1843.7 & 1675.7 & 2866.9 & 2714.4 & ----- & ----- & ----- & ----- & ----- & ----- \\
\hline 1901 & 1820.2 & 1623.0 & 1800.2 & 1604.6 & 2838.0 & 2554.4 & ----- & ----- & ----- & ----- & & \\
\hline 1902 & 1721.2 & 1513.1 & 1701.7 & 1494.4 & 2745.4 & 2452.4 & ----- & ----- & ----- & ----- & ----- & --- \\
\hline 1903 & 1745.3 & 1546.9 & 1724.3 & 1526.2 & 2853.2 & 2589.6 & ----- & ----- & ----- & ----- & ----- & ----- \\
\hline 1904 & 1839.2 & 1619.8 & 1815.6 & 1597.8 & 3069.5 & 2745.4 & ----- & ----- & ----- & ----- & ----- & ----- \\
\hline 1905 & 1779.6 & 1567.9 & 1756.7 & 1545.7 & 2970.3 & 2689.1 & ----- & ----- & ----- & ----- & ----- & -1 \\
\hline 1906 & 1789.8 & 1541.2 & 1762.2 & 1512.7 & 2695.7 & 2548.3 & ----- & ----- & ----- & ----- & ----- & ----- \\
\hline 1907 & 1846.0 & 1569.8 & 1818.4 & 1541.6 & 2749.6 & 2565.6 & ----- & ----- & ----- & ----- & ----- & \\
\hline 1908 & 1682.5 & 1463.1 & 1658.0 & 1438.0 & 2525.6 & 2413.5 & ----- & ----- & ----- & ----- & ----- & ----- \\
\hline 1909 & 1636.2 & 1420.0 & 1612.3 & 1396.5 & 2480.2 & 2331.0 & ----- & ----- & ----- & ----- & ----- & ----- \\
\hline 1910 & 1693.2 & 1458.8 & 1671.3 & 1437.2 & 2483.1 & 2324.3 & ----- & ----- & ----- & ----- & ----- & \\
\hline 1911 & 1617.9 & 1403.6 & 1590.7 & 1376.4 & 2443.0 & 2289.4 & ----- & ----- & ---- & ----- & ----- & \\
\hline 1912 & 1595.3 & 1365.4 & 1568.5 & 1339.2 & 2401.5 & 2218.9 & ----- & ----- & ----- & ----- & ----- & ----- \\
\hline 1913 & 1611.8 & 1373.1 & 1579.7 & 1338.3 & 2336.1 & 2201.5 & ----- & ----- & ----- & ----- & ----- & \\
\hline 1914 & 1555.7 & 1333.4 & 1521.4 & 1297.7 & 2335.6 & 2188.0 & ----- & ----- & ---- & --- & ----- & \\
\hline 1915 & 1544.0 & 1337.9 & 1508.5 & 1300.1 & 2352.9 & 2262.0 & ----- & ----- & ----- & ----- & ----- & ----- \\
\hline 1916 & 1623.7 & 1393.7 & 1581.6 & 1344.6 & 2264.5 & 2166.9 & ----- & ----- & ----- & ----- & ----- & \\
\hline 1917 & 1650.1 & 1397.8 & 1596.1 & 1338.1 & 2414.5 & 2272.8 & ----- & ----- & ---1 & --- & ----- & \\
\hline 1918 & 2085.2 & 1727.2 & 2022.9 & 1655.7 & 2891.0 & 2711.5 & ----- & ----- & ---- & ----- & ----- & -- \\
\hline 1919 & 1466.1 & 1339.6 & 1415.3 & 1274.7 & 2026.2 & 2086.8 & ----- & ----- & ----- & ----- & ----- & \\
\hline 1920 & 1470.6 & 1374.9 & 1420.6 & 1313.9 & 2042.4 & 2098.4 & ----- & ----- & ---- & --- & ----- & \\
\hline 1921 & 1317.8 & 1212.9 & 1274.8 & 1158.3 & 1803.6 & 1859.6 & ----- & ----- & ----- & ----- & ----- & -- \\
\hline 1922 & 1371.1 & 1238.2 & 1324.0 & 1181.3 & 1838.6 & 1838.7 & ----- & ----- & ----- & ----- & ----- & ----- \\
\hline 1923 & 1423.1 & 1277.8 & 1367.2 & 1213.9 & 2001.1 & 1971.1 & ----- & ----- & ---1 & ----- & ----- & -- \\
\hline 1924 & 1373.4 & 1204.8 & 1305.0 & 1132.6 & 2105.7 & 2005.7 & ----- & ----- & ---1 & ----- & ----- & -- \\
\hline 1925 & 1383.0 & 1213.6 & 1313.6 & 1141.0 & 2143.2 & 2036.3 & ----- & ----- & ---- & ----- & ----- & -- \\
\hline 1926 & 1434.1 & 1255.5 & 1363.1 & 1182.4 & 2207.2 & 2077.2 & ----- & ----- & ---- & ----- & ----- & -- \\
\hline 1927 & 1347.9 & 1162.6 & 1281.8 & 1091.4 & 2037.7 & 1926.6 & ----- & ----- & ---- & ----- & ----- & ----- \\
\hline 1928 & 1436.0 & 1235.0 & 1360.5 & 1154.8 & 2167.4 & 2024.8 & ----- & ----- & ---1 & ----- & ----- & ----- \\
\hline 1929 & 1423.0 & 1213.1 & 1344.8 & 1133.7 & 2193.0 & 2001.1 & ----- & ----- & ---- & ----- & ----- & ----- \\
\hline 1930 & 1352.0 & 1136.5 & 1272.2 & 1054.9 & 2136.5 & 1949.3 & ----- & ----- & ---- & ----- & ----- & ----- \\
\hline 1931 & 1319.3 & 1099.4 & 1242.1 & 1020.6 & 2068.0 & 1873.5 & ----- & ----- & ---- & ----- & ----- & ----- \\
\hline 1932 & 1286.4 & 1085.1 & 1219.2 & 1016.1 & 1931.3 & 1757.1 & ----- & ----- & ----- & ----- & ----- & ----- \\
\hline 1933 & 1272.4 & 1052.8 & 1201.7 & 980.2 & 1924.1 & 1738.2 & ----- & ----- & ----- & ----- & ----- & ----- \\
\hline 1934 & 1312.4 & 1066.6 & 1236.1 & 992.2 & 2016.0 & 1762.3 & ----- & ----- & ----- & ----- & ----- & ----- \\
\hline
\end{tabular}


Table 9 (cont.)

\begin{tabular}{|c|c|c|c|c|c|c|c|c|c|c|c|c|c|}
\hline & & Total & Total & White & White & $\begin{array}{l}\text { All } \\
\text { Other }\end{array}$ & $\begin{array}{l}\text { All } \\
\text { Other }\end{array}$ & Black & Black & $\begin{array}{c}\text { Amerin- } \\
\text { dian }\end{array}$ & $\begin{array}{c}\text { Amerin- } \\
\text { dian }\end{array}$ & $\begin{array}{l}\text { Asian \& } \\
\text { Pac Isl }\end{array}$ & $\begin{array}{l}\text { Asian \& } \\
\text { Pac Isl }\end{array}$ \\
\hline & & Male & Female & Male & Female & Male & Female & Male & Female & Male & Female & Male & Female \\
\hline 1935 & & 1288.6 & 1040.4 & 1228.2 & 980.0 & 1846.6 & 1605.1 & ----- & ----- & ----- & ----- & ----- & ----- \\
\hline 1936 & & 1352.0 & 1080.3 & 1282.7 & 1014.5 & 2003.9 & 1702.5 & ----- & ----- & ----- & ----- & ----- & ----- \\
\hline 1937 & & 1308.9 & 1032.8 & 1243.6 & 968.9 & 1921.7 & 1628.8 & ----- & ----- & ----- & ----- & ----- & ----- \\
\hline 1938 & & 1213.7 & 969.5 & 1154.5 & 907.4 & 1765.9 & 1551.5 & ----- & ----- & ----- & ----- & ----- & ----- \\
\hline 1939 & & 1197.7 & 950.6 & 1143.3 & 893.4 & 1706.3 & 1487.5 & ----- & ----- & ----- & ----- & ----- & ----- \\
\hline 1940 & & 1205.9 & 933.2 & 1148.2 & 873.3 & 1755.5 & 1497.2 & ----- & ----- & ----- & ----- & ----- & ----- \\
\hline 941 & & 1169.0 & 888.3 & 1113.1 & 829.5 & 1691.5 & 1433.3 & ----- & ----- & ----- & ----- & -- & ----- \\
\hline 942 & & 1132.3 & 849.8 & 1084.1 & 798.1 & 1576.8 & 1326.5 & ----- & ----- & ----- & ----- & ----- & --- \\
\hline 943 & & 1152.5 & 870.6 & 1109.3 & 820.1 & 1548.1 & 1340.1 & ----- & ----- & ----- & ----- & ----- & ----- \\
\hline 944 & & 1097.9 & 827.3 & 1058.1 & 779.2 & 1455.3 & 1266.1 & ----- & ----- & --1 & ----- & -- & - \\
\hline 945 & & 1073.7 & 795.9 & 1037.1 & 751.9 & 1393.4 & 1192.7 & ----- & ----- & & --- & & \\
\hline 1946 & & 1051.7 & 771.1 & 1018.0 & 730.6 & 1342.8 & 1134.9 & ----- & ----- & ----- & ----- & ----- & ----- \\
\hline 947 & & 1044.9 & 749.4 & 1010.4 & 706.9 & 1352.6 & 1141.9 & ----- & ----- & ----- & ----- & ----- & \\
\hline 948 & & 1031.5 & 726.5 & 993.7 & 683.8 & 1377.5 & 1121.7 & ----- & ----- & --1 & ----- & & \\
\hline 1949 & & 1007.3 & 702.2 & 970.3 & 659.1 & 1343.5 & 1105.8 & ----- & ----- & --1 & ----- & ----- & ---1 \\
\hline 1950 & & 990.4 & 681.1 & 955.4 & 639.9 & 1303.0 & 1058.2 & ----- & ----- & ----- & ----- & ----- & ----- \\
\hline 951 & & 986.1 & 670.9 & 951.9 & 631.0 & 1287.2 & 1033.0 & ----- & ----- & --1 & ----- & & \\
\hline 1952 & & 974.1 & 656.7 & 938.8 & 617.8 & 1284.0 & 1004.0 & ---- & ----- & --- & - & 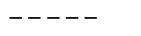 & - \\
\hline 1953 & & 967.1 & 642.7 & 933.8 & 605.5 & 1256.9 & 972.8 & ----- & ----- & ----- & ----- & ----- & ----- \\
\hline 954 & & 921.2 & 607.1 & 892.4 & 573.3 & 1164.5 & 901.8 & ----- & ----- & --1 & -- & & \\
\hline 955 & & 927.9 & 605.1 & 900.6 & 571.8 & 1154.1 & 893.3 & ----- & ----- & -- & - & ----- & -1 \\
\hline 956 & & 931.1 & 600.7 & 903.5 & 566.8 & 1159.1 & 895.7 & ----- & ----- & ----- & ----- & ----- & --- \\
\hline 57 & & 949.4 & 609.8 & 918.9 & 573.8 & 1203.7 & 920.4 & ----- & ----- & -- & -- & & \\
\hline 958 & & 938.2 & 599.2 & 908.8 & 564.0 & 1181.1 & 900.4 & ---- & ----- & -- & -- & 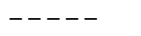 & \\
\hline 59 & $\backslash 2$ & 927.6 & 584.7 & 89 & 551.4 & 1155.8 & 863.1 & ----- & ----- & ----- & ----- & ----- & ----- \\
\hline 60 & $\backslash 3$ & 943.4 & 586.9 & 912.0 & 551.5 & 1202.7 & 886.5 & 1239.3 & 910.0 & --1 & ----- & & \\
\hline 961 & & 919.3 & 569.5 & 890.3 & 535.8 & 1155.2 & 852.9 & 1194.5 & 876.0 & --1 & ----- & ----- & \\
\hline 962 & $\backslash 4$ & 934.3 & 576.4 & 903.2 & 541.5 & 1196.2 & 873.4 & (NA) & (NA) & --- & ----- & ----- & ----- \\
\hline 1963 & $\backslash 4$ & 955.2 & 581.3 & 921.2 & 546.0 & 1248.6 & 894.2 & (NA) & (NA) & --- & ----- & 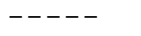 & \\
\hline 1964 & & 936.6 & 565.5 & 903.4 & 531.2 & 1203.5 & 845.0 & 1260.7 & 874.2 & ----- & ----- & ----- & ----- \\
\hline 1965 & & 942.9 & 561.2 & 909.1 & 527.6 & 1213.7 & 831.5 & 1266.8 & 859.9 & ----- & ----- & ----- & ----- \\
\hline 966 & & 951.0 & 560.9 & 915.2 & 527.1 & 1238.9 & 831.8 & 1296.4 & 861.4 & ----- & ----- & ----- & --- \\
\hline 67 & & 934.7 & 545.1 & 900.4 & 513.3 & 1207.9 & 795.9 & 1265.7 & 827.1 & ----- & ----- & ----- & ----- \\
\hline 968 & & 961.6 & 557.1 & 921.6 & 522.9 & 1286.6 & 831.2 & 1353.2 & 865.9 & ----- & ----- & ---- & \\
\hline 1969 & & 945.8 & 543.4 & 906.0 & 510.8 & 1266.5 & 800.7 & 1334.6 & 838.1 & ----- & ----- & ----- & 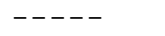 \\
\hline
\end{tabular}


Table 9 (cont.)

\begin{tabular}{|c|c|c|c|c|c|c|c|c|c|c|c|c|}
\hline & Total & Total & White & White & $\begin{array}{c}\text { All } \\
\text { Other }\end{array}$ & $\begin{array}{l}\text { All } \\
\text { Other }\end{array}$ & Black & Black & $\begin{array}{l}\text { Amerin- } \\
\text { dian }\end{array}$ & $\begin{array}{c}\text { Amerin- } \\
\text { dian }\end{array}$ & $\begin{array}{l}\text { Asian \& } \\
\text { Pac Is } 1\end{array}$ & $\begin{array}{l}\text { Asian \& } \\
\text { Pac Isl }\end{array}$ \\
\hline & Male & Female & Male & Female & Male & Female & Male & Female & Male & Female & Male & Female \\
\hline 1970 & 929.1 & 531.1 & 889.9 & 499.8 & 1241.3 & 776.3 & 1311.9 & 812.6 & ----- & ----- & ----- & \\
\hline 1971 & 911.2 & 519.0 & 874.2 & 489.1 & 1202.0 & 749.5 & 1271.6 & 784.8 & ----- & ----- & ----- & ----- \\
\hline 1972 & 916.5 & 516.6 & 878.1 & 487.6 & 1219.1 & 736.8 & 1292.6 & 773.2 & ----- & ----- & ----- & ----- \\
\hline 1973 & 904.6 & 508.1 & 867.3 & 479.3 & 1196.6 & 727.6 & 1269.1 & 765.2 & ----- & ----- & --- & -- \\
\hline 1974 & 869.7 & 487.0 & 835.1 & 461.0 & 1138.9 & 680.2 & 1212.1 & 717.1 & ---- & ---- & ---1 & ----- \\
\hline 1975 & 836.1 & 462.5 & 803.4 & 439.0 & 1087.5 & 634.7 & 1160.8 & 670.4 & ----- & ----- & ----- & ----- \\
\hline 976 & 820.0 & 455.0 & 788.5 & 432.4 & 1061.0 & 618.2 & 1135.9 & 654.4 & ----- & ----- & ----- & ---- \\
\hline 1977 & 800.4 & 441.8 & 769.9 & 419.6 & 1033.9 & 601.8 & 1109.7 & 639.4 & --1 & & & \\
\hline 1978 & 790.6 & 437.4 & 760.4 & 416.4 & 1018.2 & 585.3 & 1091.8 & 622.6 & ----- & ----- & ----- & ----- \\
\hline 979 & 767.7 & 423.0 & 737.8 & 402.5 & 991.8 & 566.6 & 1071.1 & 605.2 & ----- & ----- & ----- & ----- \\
\hline 1980 & 772.8 & 430.4 & 741.6 & 409.2 & 1004.0 & 576.9 & 1103.9 & 626.8 & 732.5 & 414.1 & 416.6 & 224.6 \\
\hline 981 & 753.0 & 420.8 & 724.2 & 401.5 & 962.2 & 551.4 & 1066.6 & 602.6 & 676.7 & 368.5 & 382.3 & 213.9 \\
\hline 1982 & 733.5 & 411.9 & 706.2 & 393.6 & 929.1 & 533.8 & 1033.4 & 585.7 & 634.6 & 371.6 & 389.2 & 212.8 \\
\hline 1983 & 728.7 & 412.4 & 701.1 & 393.2 & 927.0 & 540.1 & 1035.5 & 595.3 & 634.0 & 360.1 & 388.6 & 218.0 \\
\hline 1984 & 720.9 & 410.4 & 693.0 & 391.7 & 919.7 & 533.2 & 1033.1 & 589.9 & 614.2 & 347.3 & 386.0 & 223.0 \\
\hline 985 & 722.3 & 410.3 & 692.7 & 391.0 & 930.1 & 535.5 & 1051.1 & 594.5 & 602.6 & 353.3 & 396.9 & 228.5 \\
\hline 1986 & 715.5 & 407.6 & 684.3 & 388.1 & 929.9 & 530.6 & 1059.6 & 594.0 & 591.6 & 328.4 & 385.3 & 220.3 \\
\hline 987 & 706.1 & 404.6 & 673.6 & 384.8 & 925.7 & 527.4 & 1060.8 & 592.4 & 580.8 & 351.3 & 386.2 & 221.3 \\
\hline 1988 & 705.4 & 406.1 & 670.7 & 385.3 & 935.9 & 532.6 & 1080.1 & 600.9 & 585.7 & 343.2 & 385.4 & 226.5 \\
\hline 1989 & 688.5 & 397.3 & 651.6 & 376.0 & 930.6 & 525.1 & 1079.5 & 594.0 & 622.8 & 353.4 & 378.9 & 225.2 \\
\hline 990 & 676.2 & 389.0 & 640.8 & 368.5 & 901.2 & 508.6 & 1052.7 & 578.8 & 573.1 & 335.1 & 377.8 & 228.9 \\
\hline 991 & 668.5 & 386.3 & 632.8 & 365.9 & 890.6 & 503.9 & 1047.0 & 576.1 & 562.6 & 335.9 & 360.2 & 218.3 \\
\hline 1992 & 655.1 & 380.2 & 620.2 & 359.8 & 868.5 & 494.3 & 1022.9 & 567.6 & 579.6 & 343.1 & 364.1 & 220.5 \\
\hline 1993 & 663.5 & 388.4 & 626.6 & 367.9 & 885.2 & 501.9 & 1048.8 & 578.7 & 589.6 & 364.5 & 381.4 & 226.7 \\
\hline 1994 & 653.0 & 385.4 & 616.9 & 365.2 & 866.1 & 494.8 & 1026.9 & 572.5 & 585.9 & 350.8 & 386.5 & 229.3 \\
\hline 1995 & 644.5 & 385.1 & 609.3 & 365.0 & 852.1 & 492.8 & 1014.4 & 571.8 & 580.4 & 368.0 & 384.4 & 231.4 \\
\hline 996 & 623.4 & 380.8 & 591.2 & 361.7 & 811.0 & 481.2 & 965.0 & 560.4 & 555.9 & 367.7 & 355.8 & 214.4 \\
\hline & 602.5 & 375.7 & 573.5 & 358.0 & 769.3 & 468.1 & 910.9 & 545.4 & & 359.9 & 350.3 & 214.7 \\
\hline 98 & 589.4 & 372.5 & 562.4 & 355.2 & ----- & ----- & 884.5 & 540.9 & 564.9 & 363.3 & 336.2 & 207.4 \\
\hline
\end{tabular}

$\backslash 1$ The overall death rate and the age-adjusted death rate are per 100,000 population. Prior to 1933 , this is for the Death Registration States only.

$\backslash 2$ Includes Alaska.

13 Denotes first year for which figures includes Alaska and Hawaii.

$\backslash 4$ Excludes New Jersey for rates by race. That state did not require reporting of race.

Source: Total deaths: 1900-1992, U.S. Public Health Service, National Center for Health Statistics, Vital Statistics of the United States, 1992, vol. II, part A "Mortality", Tables 1-2 and 1-3. $1993-1997$ and data for the Amerindian and Asian and

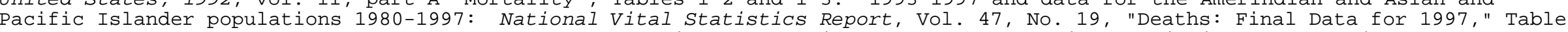

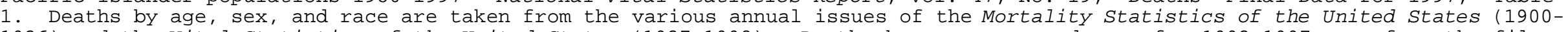

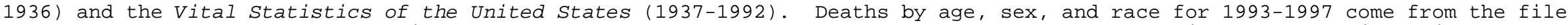
"GMWK291A" found on the NCHS website (www.cdc.gov/nchs/datawh/statab/unpubd/mortabs.htm) Population: Death Registration Area, 1900-1932, and United States, 1933-1939, Forrest Linder and Robert D. Grove, Vital Statistics Rates in the United States, 1900-1940, pp. 997-1034 and unpublished tables made available by the Mortality Statistics Branch of the National Center for

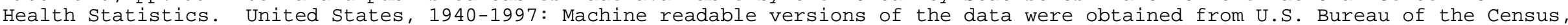

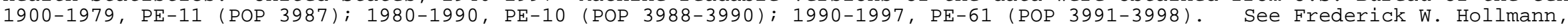

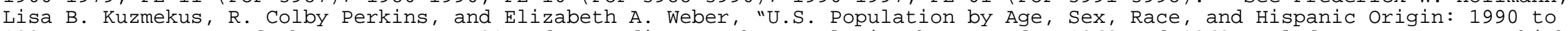

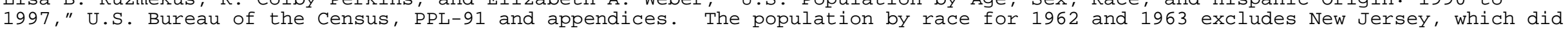


not report deaths by race in those years. The estimated population of the United States for whites and all other races was

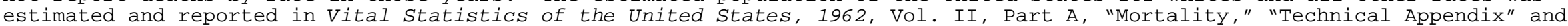

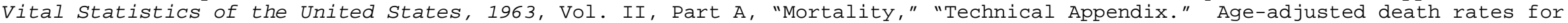

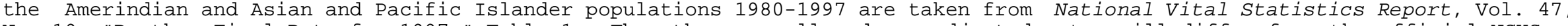
No. 19, "Deaths: Final Data for 1997," Table 1. The other overall and age-adjusted rates will differ from the official NCHS

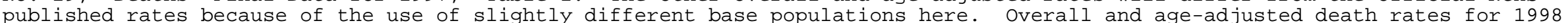

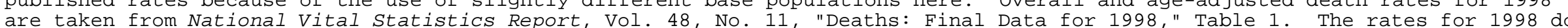
not use the same base population estimates as for the period 1940-1997. The same standard is used for the age adjustment. 
Table 10. Ratio of Infant and Maternal Mortality to White Mortality. By Race. United States, 1850 to 1998.

\begin{tabular}{|c|c|c|c|c|c|c|c|}
\hline & $\begin{array}{c}\text { RATIO TO } \\
\text { Neonatal } \\
\text { Rate }\end{array}$ & $\begin{array}{l}\text { HITE } \\
\text { ortality }\end{array}$ & $\begin{array}{c}\text { Infant Mo } \\
\text { Rate }\end{array}$ & tality & & $\begin{array}{c}\text { Maternal } \\
\text { Rate }\end{array}$ & Mortality \\
\hline Year & All Other & Black & All Other & Black & Hispanic & All Other & Black \\
\hline 1850 & & & & 1.568 & & & \\
\hline 1900 & & & & 1.422 & & & \\
\hline 1910 & & & & 1.478 & & & \\
\hline 1915 & & & 1.838 & & & 1.757 & \\
\hline 1916 & 1.584 & 1.584 & 1.868 & 1.862 & & 1.939 & \\
\hline 1917 & 1.362 & & 1.665 & & & 1.862 & \\
\hline 1918 & 1.397 & 1.406 & 1.655 & 1.668 & & 1.567 & \\
\hline 1919 & 1.370 & 1.454 & 1.572 & 1.618 & & 1.787 & \\
\hline 1920 & 1.361 & 1.399 & 1.604 & 1.652 & & 1.686 & \\
\hline 1921 & 1.300 & 1.326 & 1.497 & 1.527 & & 1.672 & \\
\hline 1922 & 1.286 & 1.307 & 1.503 & 1.525 & & 1.701 & \\
\hline 1923 & 1.293 & 1.332 & 1.597 & 1.631 & & 1.749 & \\
\hline 1924 & 1.369 & 1.385 & 1.690 & 1.708 & & 1.942 & \\
\hline 1925 & 1.345 & 1.367 & 1.622 & 1.640 & & 1.927 & \\
\hline 1926 & 1.294 & 1.302 & 1.597 & 1.601 & & 1.730 & \\
\hline 1927 & 1.317 & 1.323 & 1.652 & 1.649 & & 1.907 & \\
\hline 1928 & 1.367 & 1.375 & 1.659 & 1.655 & & 1.930 & \\
\hline 1929 & 1.329 & 1.334 & 1.617 & 1.606 & & 1.900 & \\
\hline 1930 & 1.386 & 1.392 & 1.662 & 1.656 & & 1.928 & \\
\hline 1931 & 1.361 & 1.367 & 1.622 & 1.615 & & 1.854 & \\
\hline 1932 & 1.366 & 1.388 & 1.617 & 1.578 & & 1.680 & \\
\hline 1933 & 1.427 & 1.424 & 1.729 & 1.617 & & 1.935 & 1.802 \\
\hline 1934 & 1.402 & 1.424 & 1.732 & 1.670 & & 1.879 & 1.741 \\
\hline 1935 & 1.377 & 1.377 & 1.603 & 1.578 & & 1.782 & 1.799 \\
\hline 1936 & 1.416 & 1.413 & 1.656 & 1.628 & & 1.900 & 1.917 \\
\hline 1937 & 1.418 & 1.421 & 1.654 & 1.630 & & 1.969 & 1.977 \\
\hline 1938 & 1.382 & 1.385 & 1.679 & 1.654 & & 2.252 & 2.283 \\
\hline 1939 & 1.424 & 1.428 & 1.675 & 1.652 & & 2.160 & 2.186 \\
\hline 1940 & 1.460 & 1.467 & 1.708 & 1.688 & & 2.419 & 2.444 \\
\hline 1941 & 1.494 & 1.506 & 1.816 & 1.799 & & 2.549 & 2.595 \\
\hline 1942 & 1.412 & 1.424 & 1.732 & 1.721 & & 2.453 & 2.476 \\
\hline 1943 & 1.388 & 1.397 & 1.667 & 1.640 & & 2.422 & 2.436 \\
\hline 1944 & 1.377 & 1.386 & 1.634 & 1.607 & & 2.672 & 2.713 \\
\hline 1945 & 1.373 & 1.382 & 1.601 & 1.579 & & 2.643 & 2.654 \\
\hline 1946 & 1.364 & 1.372 & 1.557 & 1.535 & & 2.746 & 2.782 \\
\hline 1947 & 1.429 & 1.433 & 1.611 & 1.585 & & 3.081 & 3.096 \\
\hline 1948 & 1.373 & 1.382 & 1.555 & 1.528 & & 3.367 & 3.396 \\
\hline 1949 & 1.409 & 1.419 & 1.637 & 1.619 & & 3.448 & 3.489 \\
\hline 1950 & 1.418 & 1.433 & 1.660 & 1.638 & & 3.627 & 3.650 \\
\hline 1951 & 1.444 & 1.460 & 1.736 & 1.717 & & 3.667 & 3.719 \\
\hline 1952 & 1.514 & 1.541 & 1.843 & 1.839 & & 3.847 & 3.869 \\
\hline 1953 & 1.497 & 1.519 & 1.788 & 1.780 & & 3.766 & 3.816 \\
\hline 1954 & 1.517 & 1.545 & 1.795 & 1.795 & & 3.866 & 3.922 \\
\hline 1955 & 1.537 & 1.571 & 1.814 & 1.826 & & 3.973 & 4.095 \\
\hline 1956 & 1.543 & 1.577 & 1.815 & 1.828 & & 3.857 & 3.983 \\
\hline 1957 & 1.589 & 1.629 & 1.876 & 1.897 & & 4.302 & 4.422 \\
\hline 1958 & 1.629 & 1.669 & 1.920 & 1.945 & & 3.871 & 3.973 \\
\hline
\end{tabular}


Table 10 (cont.)

\begin{tabular}{|c|c|c|c|c|c|c|c|}
\hline \multirow[b]{2}{*}{ Year } & $\begin{array}{c}\text { RATIO TO } \\
\text { Neonatal } \\
\text { Rate }\end{array}$ & $\begin{array}{l}\text { HITE } \\
\text { ortality }\end{array}$ & $\begin{array}{c}\text { Infant Mor } \\
\text { Rate }\end{array}$ & fality & & $\begin{array}{c}\text { Maternal } \\
\text { Rate }\end{array}$ & Mortality \\
\hline & All Other & Black & All Other & Black & Hispanic & All Other & Black \\
\hline 1959 & 1.583 & 1.623 & 1.897 & 1.931 & & 3.957 & 4.070 \\
\hline 1960 & 1.564 & 1.616 & 1.886 & 1.934 & & 3.765 & 3.985 \\
\hline 1961 & 1.550 & 1.604 & 1.817 & 1.866 & & 4.068 & 4.233 \\
\hline 1962 & 1.544 & 1.604 & 1.857 & 1.910 & & 4.029 & 4.176 \\
\hline 1963 & 1.563 & 1.617 & 1.869 & 1.928 & & 4.038 & 4.213 \\
\hline 1964 & 1.636 & 1.698 & 1.903 & 1.958 & & 4.031 & 4.206 \\
\hline 1965 & 1.578 & 1.646 & 1.874 & 1.940 & & 3.986 & 4.205 \\
\hline 1966 & 1.590 & 1.660 & 1.883 & 1.951 & & 3.584 & 3.673 \\
\hline 1967 & 1.587 & 1.667 & 1.822 & 1.904 & & 3.564 & 3.723 \\
\hline 1968 & 1.565 & 1.653 & 1.797 & 1.885 & & 3.831 & 3.970 \\
\hline 1969 & 1.585 & 1.683 & 1.788 & 1.891 & & 3.594 & 3.839 \\
\hline 1970 & 1.551 & 1.638 & 1.736 & 1.831 & & 3.882 & 4.153 \\
\hline 1971 & 1.508 & 1.615 & 1.667 & 1.772 & & 3.485 & 3.715 \\
\hline 1972 & 1.548 & 1.669 & 1.689 & 1.805 & & 2.692 & 2.846 \\
\hline 1973 & 1.517 & 1.636 & 1.658 & 1.778 & & 3.234 & 3.589 \\
\hline 1974 & 1.550 & 1.685 & 1.682 & 1.811 & & 3.510 & 3.830 \\
\hline 1975 & 1.615 & 1.760 & 1.704 & 1.845 & & 3.187 & 3.440 \\
\hline 1976 & 1.680 & 1.845 & 1.767 & 1.917 & & 2.944 & 3.278 \\
\hline 1977 & 1.690 & 1.851 & 1.764 & 1.919 & & 3.377 & 3.792 \\
\hline 1978 & 1.667 & 1.845 & 1.758 & 1.925 & & 3.594 & 3.906 \\
\hline 1979 & 1.633 & 1.810 & 1.737 & 1.912 & & 3.547 & 3.922 \\
\hline 1980 & 1.784 & 1.973 & 1.853 & 2.037 & & 2.955 & 3.209 \\
\hline 1981 & 1.786 & 2.000 & 1.825 & 2.019 & & 2.746 & 3.238 \\
\hline 1982 & 1.791 & 2.030 & 1.848 & 2.071 & & 2.828 & 2.793 \\
\hline 1983 & 1.810 & 2.048 & 1.854 & 2.083 & & 2.763 & 3.102 \\
\hline 1984 & 1.787 & 2.016 & 1.839 & 2.065 & & 3.130 & 3.648 \\
\hline 1985 & 1.833 & 2.100 & 1.826 & 2.065 & & 3.481 & 3.923 \\
\hline 1986 & 1.895 & 2.158 & 1.898 & 2.148 & & 3.265 & 3.837 \\
\hline 1987 & 1.981 & 2.278 & 1.941 & 2.212 & & 2.353 & 2.784 \\
\hline 1988 & 1.943 & 2.283 & 1.917 & 2.202 & & 2.949 & 3.305 \\
\hline 1989 & 2.020 & 2.333 & 2.012 & 2.296 & 1.210 & 2.702 & 3.070 \\
\hline 1990 & 2.063 & 2.417 & 2.039 & 2.368 & 1.197 & 3.236 & 3.836 \\
\hline 1991 & 2.111 & 2.489 & 2.068 & 2.411 & 1.219 & 2.458 & 2.915 \\
\hline 1992 & 2.140 & 2.512 & 2.087 & 2.435 & 1.232 & 3.294 & 3.824 \\
\hline 1993 & 2.093 & 2.488 & 2.074 & 2.426 & 1.235 & 3.667 & 4.271 \\
\hline 1994 & 2.048 & 2.429 & 2.045 & 2.394 & 1.212 & 2.613 & 2.984 \\
\hline 1995 & 1.976 & 2.390 & 2.000 & 2.397 & 1.206 & 4.405 & 5.262 \\
\hline 1996 & 1.975 & 2.400 & 2.000 & 2.410 & 1.197 & 3.314 & 3.980 \\
\hline 1997 & 1.925 & 2.350 & 1.967 & 2.367 & 1.200 & 3.155 & 3.586 \\
\hline 1998 & 1.975 & 2.375 & 1.983 & 2.383 & 1.200 & 2.922 & 3.353 \\
\hline
\end{tabular}

Source: Table 7 . 
Table 11. Ratio of White to Nonwhite and Black Expectations of Life at Birth. Differences of White and Nonwhite and Black Expectations of Life at Birth. By Sex. United States, 1900 to 1998.

\begin{tabular}{|c|c|c|c|c|c|c|c|c|}
\hline \multirow[b]{2}{*}{ Year } & \multicolumn{3}{|c|}{ EXPECTATION OF LIFE AT BIRTH. } & & \multicolumn{4}{|c|}{$\begin{array}{l}\text { DIFFERENCE IN YEARS OF } \\
\text { EXPECTATION OF LIFE AT BIRTH }\end{array}$} \\
\hline & Male & Female & Male & Female & Male & Female & Male & Female \\
\hline $\begin{array}{l}1900 \\
1910\end{array}$ & & & $\begin{array}{l}0.833 \\
0.843\end{array}$ & $\begin{array}{l}0.854 \\
0.852\end{array}$ & & & $\begin{array}{l}8.1 \\
8.3\end{array}$ & $\begin{array}{l}7.4 \\
8.3\end{array}$ \\
\hline 1900 & 0.697 & 0.688 & & & 14.1 & 15.2 & & \\
\hline 1901 & 0.671 & 0.692 & & & 15.8 & 15.7 & & \\
\hline 1902 & 0.655 & 0.677 & & & 17.3 & 17.4 & & \\
\hline 1903 & 0.640 & 0.659 & & & 17.8 & 17.9 & & \\
\hline 1904 & 0.624 & 0.661 & & & 17.5 & 16.8 & & \\
\hline 1905 & 0.622 & 0.654 & & & 18.0 & 17.5 & & \\
\hline 1906 & 0.672 & 0.660 & & & 15.5 & 17.5 & & \\
\hline 1907 & 0.676 & 0.675 & & & 14.9 & 16.4 & & \\
\hline 1908 & 0.677 & 0.675 & & & 16.1 & 17.3 & & \\
\hline 1909 & 0.672 & 0.688 & & & 16.7 & 16.9 & & \\
\hline 1910 & 0.695 & 0.721 & & & 14.8 & 14.5 & & \\
\hline 1911 & 0.674 & 0.696 & & & 16.7 & 16.7 & & \\
\hline 1912 & 0.692 & 0.712 & & & 16.0 & 16.2 & & \\
\hline 1913 & 0.722 & 0.724 & & & 14.1 & 15.4 & & \\
\hline 1914 & 0.704 & 0.710 & & & 15.6 & 16.7 & & \\
\hline 1915 & 0.706 & 0.704 & & & 15.6 & 17.0 & & \\
\hline 1916 & 0.789 & 0.781 & & & 10.6 & 12.1 & & \\
\hline 1917 & 0.751 & 0.738 & & & 12.3 & 14.5 & & \\
\hline 1918 & 0.806 & 0.752 & & & 7.2 & 10.7 & & \\
\hline 1919 & 0.817 & 0.774 & & & 10.0 & 13.0 & & \\
\hline 1920 & 0.836 & 0.813 & & & 8.9 & 10.4 & & \\
\hline 1921 & 0.849 & 0.816 & & & 9.2 & 11.6 & & \\
\hline 1922 & 0.876 & 0.856 & & & 7.3 & 8.9 & & \\
\hline 1923 & 0.835 & 0.820 & & & 9.4 & 10.7 & & \\
\hline 1924 & 0.761 & 0.754 & & & 14.3 & 15.6 & & \\
\hline 1925 & 0.757 & 0.748 & & & 14.4 & 15.7 & & \\
\hline 1926 & 0.767 & 0.765 & & & 13.3 & 14.0 & & \\
\hline 1927 & 0.787 & 0.765 & & & 12.9 & 15.0 & & \\
\hline 1928 & 0.800 & 0.783 & & & 11.4 & 13.0 & & \\
\hline 1929 & 0.799 & 0.793 & & & 11.5 & 12.5 & & \\
\hline 1930 & 0.792 & 0.775 & & & 12.4 & 14.3 & & \\
\hline 1931 & 0.814 & 0.796 & & & 11.3 & 13.2 & & \\
\hline 1932 & 0.852 & 0.847 & & & 9.2 & 9.9 & & \\
\hline 1933 & 0.853 & 0.845 & & & 9.2 & 10.3 & & \\
\hline 1934 & 0.992 & 0.831 & & & 0.4 & 10.9 & & \\
\hline 1935 & 0.841 & 0.849 & & & 9.7 & 9.8 & & \\
\hline 1936 & 0.810 & 0.830 & & & 11.0 & 10.5 & & \\
\hline 1937 & 0.815 & 0.823 & & & 11.0 & 11.3 & & \\
\hline 1938 & 0.818 & 0.813 & & & 11.5 & 12.5 & & \\
\hline 1939 & 0.840 & 0.841 & & & 10.1 & 10.6 & & \\
\hline 1940 & 0.829 & 0.824 & & & 10.6 & 11.7 & & \\
\hline 1941 & 0.815 & 0.807 & & & 11.9 & 13.2 & & \\
\hline 1942 & 0.841 & 0.839 & & & 10.5 & 11.2 & & \\
\hline 1943 & 0.877 & 0.854 & & & 7.8 & 9.6 & & \\
\hline
\end{tabular}


Table 11 (cont.)

\begin{tabular}{|c|c|c|c|c|c|c|c|c|}
\hline \multirow[b]{2}{*}{ Year } & \multicolumn{4}{|c|}{$\begin{array}{l}\text { EXPECTATION OF LIFE AT BIRTH. } \\
\text { RATIO OF WHITE TO: }\end{array}$} & \multicolumn{4}{|c|}{$\begin{array}{l}\text { DIFFERENCE IN YEARS OF } \\
\text { EXPECTATION OF LIFE AT BIRTH }\end{array}$} \\
\hline & Male & Female & Male & Female & Male & Female & Male & Female \\
\hline 1944 & 0.865 & 0.844 & & & 8.7 & 10.7 & & \\
\hline 1945 & 0.871 & 0.858 & & & 8.3 & 9.9 & & \\
\hline 1946 & 0.883 & 0.868 & & & 7.6 & 9.3 & & \\
\hline 1947 & 0.888 & 0.878 & & & 7.3 & 8.6 & & \\
\hline 1948 & 0.887 & 0.880 & & & 7.4 & 8.5 & & \\
\hline 1949 & 0.890 & 0.872 & & & 7.3 & 9.2 & & \\
\hline 1950 & 0.889 & 0.871 & & & 7.4 & 9.3 & & \\
\hline 1951 & 0.890 & 0.876 & & & 7.3 & 9.0 & & \\
\hline 1952 & 0.887 & 0.879 & & & 7.5 & 8.8 & & \\
\hline 1953 & 0.894 & 0.884 & & & 7.1 & 8.5 & & \\
\hline 1954 & 0.905 & 0.894 & & & 6.4 & 7.8 & & \\
\hline 1955 & 0.911 & 0.897 & & & 6.0 & 7.6 & & \\
\hline 1956 & 0.908 & 0.894 & & & 6.2 & 7.8 & & \\
\hline 1957 & 0.897 & 0.889 & & & 7.0 & 8.2 & & \\
\hline 1958 & 0.905 & 0.890 & & & 6.4 & 8.1 & & \\
\hline 1959 & 0.908 & 0.896 & & & 6.2 & 7.7 & & \\
\hline 1960 & 0.907 & 0.895 & & & 6.3 & 7.8 & & \\
\hline 1961 & 0.914 & 0.899 & & & 5.8 & 7.5 & & \\
\hline 1962 & 0.910 & 0.898 & & & 6.1 & 7.6 & & \\
\hline 1963 & 0.905 & 0.895 & & & 6.4 & 7.8 & & \\
\hline 1964 & 0.905 & 0.901 & & & 6.4 & 7.4 & & \\
\hline 1965 & 0.905 & 0.904 & & & 6.4 & 7.2 & & \\
\hline 1966 & 0.902 & 0.904 & & & 6.6 & 7.2 & & \\
\hline 1967 & 0.906 & 0.911 & & & 6.4 & 6.7 & & \\
\hline 1968 & 0.895 & 0.905 & & & 7.1 & 7.1 & & \\
\hline 1969 & 0.895 & 0.911 & & & 7.1 & 6.7 & & \\
\hline 1970 & 0.901 & 0.918 & 0.882 & 0.903 & 6.7 & 6.2 & 8.0 & 7.3 \\
\hline 1971 & 0.902 & 0.921 & 0.886 & 0.909 & 6.7 & 6.0 & 7.8 & 6.9 \\
\hline 1972 & 0.900 & 0.924 & 0.884 & 0.910 & 6.8 & 5.8 & 7.9 & 6.8 \\
\hline 1973 & 0.905 & 0.924 & 0.889 & 0.911 & 6.5 & 5.8 & 7.6 & 6.8 \\
\hline 1974 & 0.912 & 0.930 & 0.894 & 0.917 & 6.1 & 5.4 & 7.3 & 6.4 \\
\hline 1975 & 0.917 & 0.937 & 0.898 & 0.922 & 5.8 & 4.9 & 7.1 & 6.0 \\
\hline 1976 & 0.918 & 0.938 & 0.900 & 0.924 & 5.7 & 4.8 & 7.0 & 5.9 \\
\hline 1977 & 0.922 & 0.940 & 0.903 & 0.924 & 5.5 & 4.7 & 6.8 & 5.9 \\
\hline 1978 & 0.923 & 0.942 & 0.905 & 0.928 & 5.4 & 4.5 & 6.7 & 5.6 \\
\hline 1979 & 0.924 & 0.945 & 0.904 & 0.930 & 5.4 & 4.3 & 6.8 & 5.5 \\
\hline 1980 & 0.924 & 0.942 & 0.902 & 0.928 & 5.4 & 4.5 & 6.9 & 5.6 \\
\hline 1981 & 0.931 & 0.949 & 0.907 & 0.934 & 4.9 & 4.0 & 6.6 & 5.2 \\
\hline 1982 & 0.934 & 0.952 & 0.910 & 0.935 & 4.7 & 3.8 & 6.4 & 5.1 \\
\hline 1983 & 0.936 & 0.949 & 0.911 & 0.934 & 4.6 & 4.0 & 6.4 & 5.2 \\
\hline 1984 & 0.936 & 0.952 & 0.909 & 0.935 & 4.6 & 3.8 & 6.5 & 5.1 \\
\hline 1985 & 0.933 & 0.950 & 0.905 & 0.933 & 4.8 & 3.9 & 6.8 & 5.3 \\
\hline 1986 & 0.929 & 0.951 & 0.901 & 0.931 & 5.1 & 3.9 & 7.1 & 5.4 \\
\hline 1987 & 0.928 & 0.951 & 0.897 & 0.930 & 5.2 & 3.9 & 7.4 & 5.5 \\
\hline 1988 & 0.924 & 0.948 & 0.892 & 0.928 & 5.5 & 4.1 & 7.8 & 5.7 \\
\hline 1989 & 0.920 & 0.946 & 0.887 & 0.926 & 5.8 & 4.3 & 8.2 & 5.9 \\
\hline 1990 & 0.922 & 0.947 & 0.887 & 0.927 & 5.7 & 4.2 & 8.2 & 5.8 \\
\hline 1991 & 0.923 & 0.948 & 0.886 & 0.927 & 5.6 & 4.1 & 8.3 & 5.8 \\
\hline 1992 & 0.925 & 0.949 & 0.888 & 0.926 & 5.5 & 4.1 & 8.2 & 5.9 \\
\hline
\end{tabular}


Table 11 (cont.)

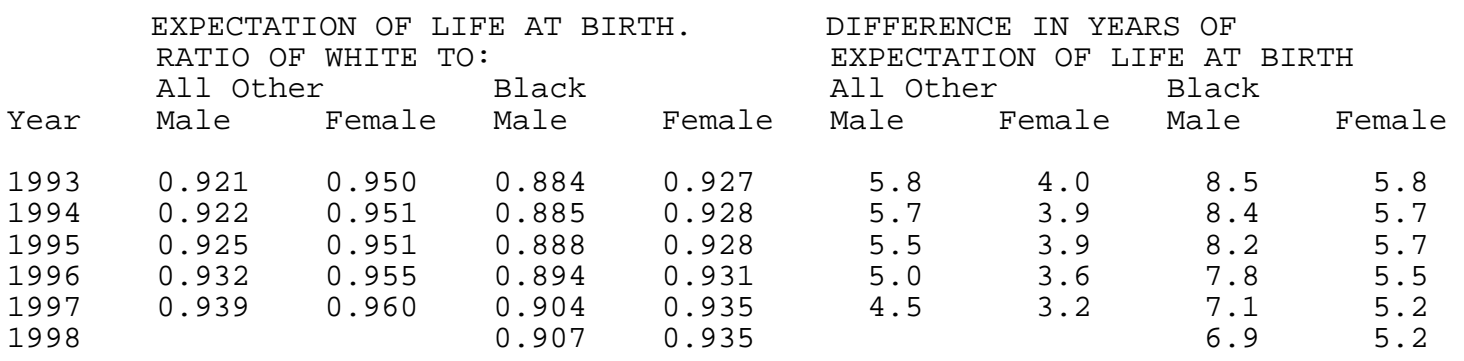

Source: Table 8 . 
Table 12. Ratio of Age-Adjusted Death Rates to Rates for Whites. By Sex and Race. United States, $1900-1998$.

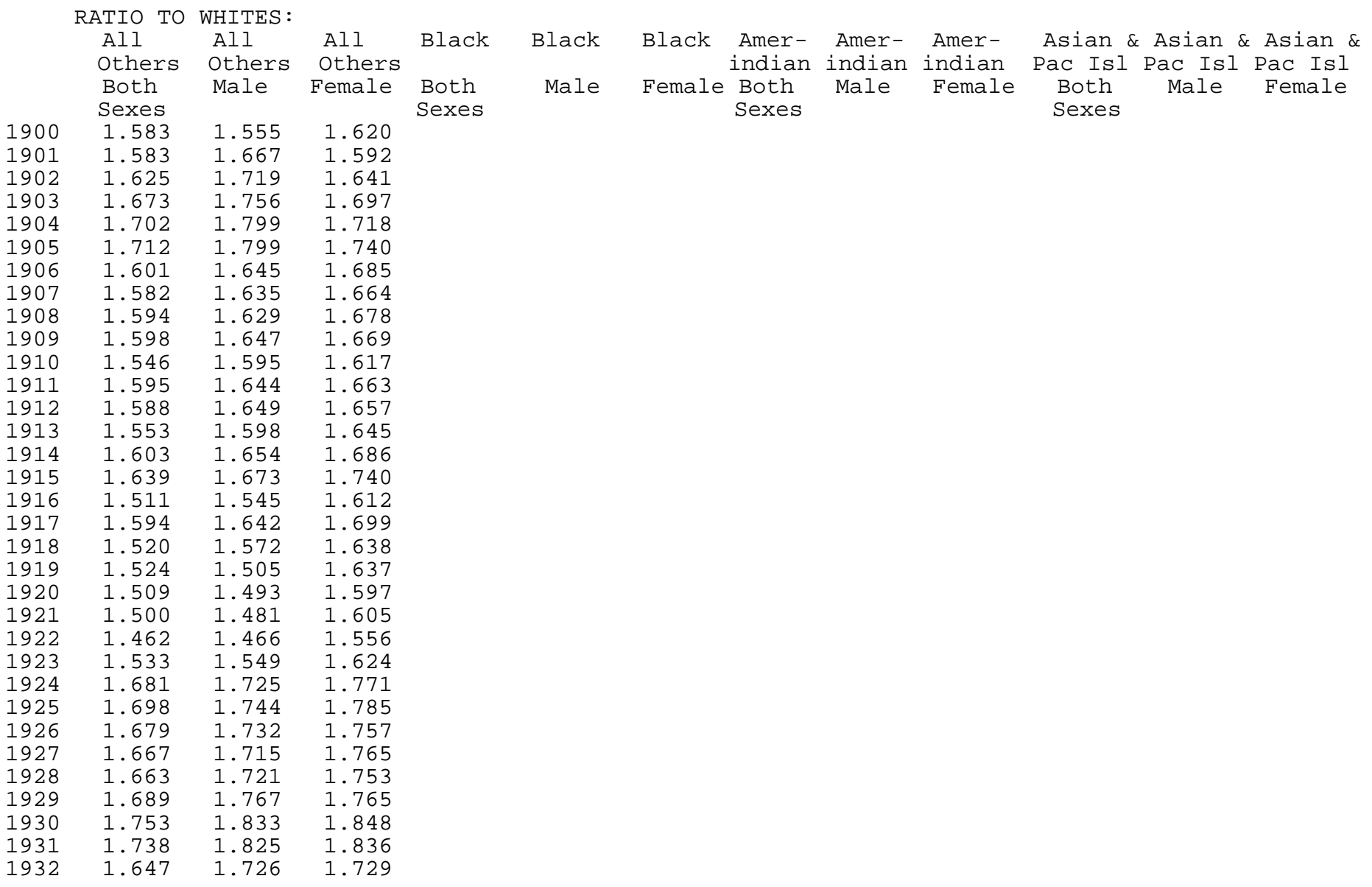


Table 12 (cont.)

\begin{tabular}{|c|c|c|c|c|c|c|c|c|c|c|}
\hline & $\begin{array}{l}\text { All } \\
\text { Others } \\
\text { Both }\end{array}$ & $\begin{array}{l}\text { All } \\
\text { Others } \\
\text { Male }\end{array}$ & $\begin{array}{l}\text { All } \\
\text { Others } \\
\text { Female }\end{array}$ & Black & $\begin{array}{l}\text { Black } \\
\text { Male }\end{array}$ & $\begin{array}{l}\text { Black } \\
\text { Female }\end{array}$ & $\begin{array}{l}\text { Amer- } \\
\text { indian } \\
\text { Both }\end{array}$ & $\begin{array}{l}\text { Amer- } \\
\text { indian } \\
\text { Male }\end{array}$ & $\begin{array}{l}\text { Amer- } \\
\text { indian } \\
\text { Female }\end{array}$ & $\begin{array}{c}\text { Asian \& Asian \& Asian \& } \\
\text { Pac Isl Pac Isl Pac Isl } \\
\text { Both Male Female }\end{array}$ \\
\hline 1933 & $\begin{array}{c}\text { Sexes } \\
1.675\end{array}$ & 1.761 & 1.773 & Sexes & & & & & & \\
\hline 1935 & 1.561 & 1.671 & 1.638 & & & & & & & \\
\hline 1936 & 1.612 & 1.743 & 1.678 & & & & & & & \\
\hline 1937 & 1.604 & 1.736 & 1.681 & & & & & & & \\
\hline 1938 & 1.608 & 1.712 & 1.710 & & & & & & & \\
\hline 1941 & 1.609 & 1.742 & 1.728 & & & & & & & \\
\hline 1942 & 1.543 & 1.676 & 1.662 & & & & & & & \\
\hline 1943 & 1.498 & 1.606 & 1.634 & & & & & & & \\
\hline 1944 & 1.483 & 1.586 & 1.625 & & & & & & & \\
\hline 1945 & 1.448 & 1.560 & 1.586 & & & & & & & \\
\hline 1946 & 1.420 & 1.539 & 1.553 & & & & & & & \\
\hline 1947 & 1.456 & 1.579 & 1.615 & & & & & & & \\
\hline 1953 & 1.454 & 1.643 & 1.606 & & & & & & & \\
\hline 1954 & 1.416 & 1.600 & 1.573 & & & & & & & \\
\hline 1955 & 1.397 & 1.580 & 1.562 & & & & & & & \\
\hline 1956 & 1.405 & 1.591 & 1.580 & & & & & & & \\
\hline 1957 & 1.431 & 1.628 & 1.604 & & & & & & & \\
\hline 1958 & 1.422 & 1.621 & 1.597 & & & & & & & \\
\hline 1959 & 1.400 & 1.612 & 1.565 & & & & & & & \\
\hline 1960 & 1.437 & 1.665 & 1.607 & 1.476 & 1.359 & 1.650 & & & & \\
\hline 1961 & 1.419 & 1.643 & 1.592 & 1.459 & 1.342 & 1.635 & & & & \\
\hline 1962 & 1.443 & 1.681 & 1.613 & & & & & & & \\
\hline 1963 & 1.472 & 1.730 & 1.638 & & & & & & & \\
\hline 1964 & 1.440 & 1.708 & 1.591 & 1.497 & 1.396 & 1.646 & & & & \\
\hline 965 & 1.436 & 1.724 & 1.576 & 1.489 & 1.393 & 1.630 & & & & \\
\hline 1966 & 1.448 & 1.755 & 1.578 & 1.505 & 1.417 & 1.634 & & & & \\
\hline
\end{tabular}


Table 12 (cont.)

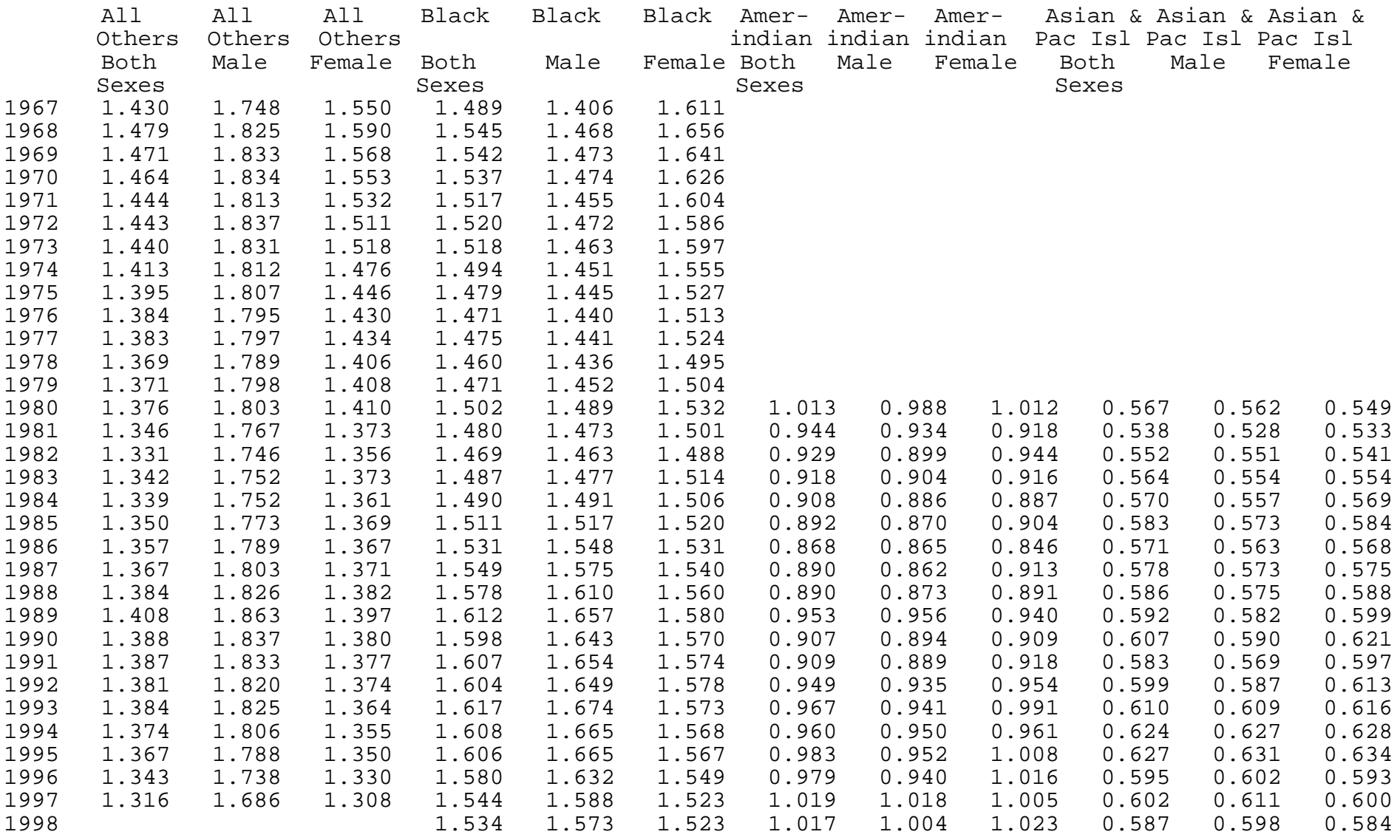

Source: Table 9. 
Table 13. Nuptiality Measures by Race, Nativity, \& Ethnicity. United States, $1880-1990$.

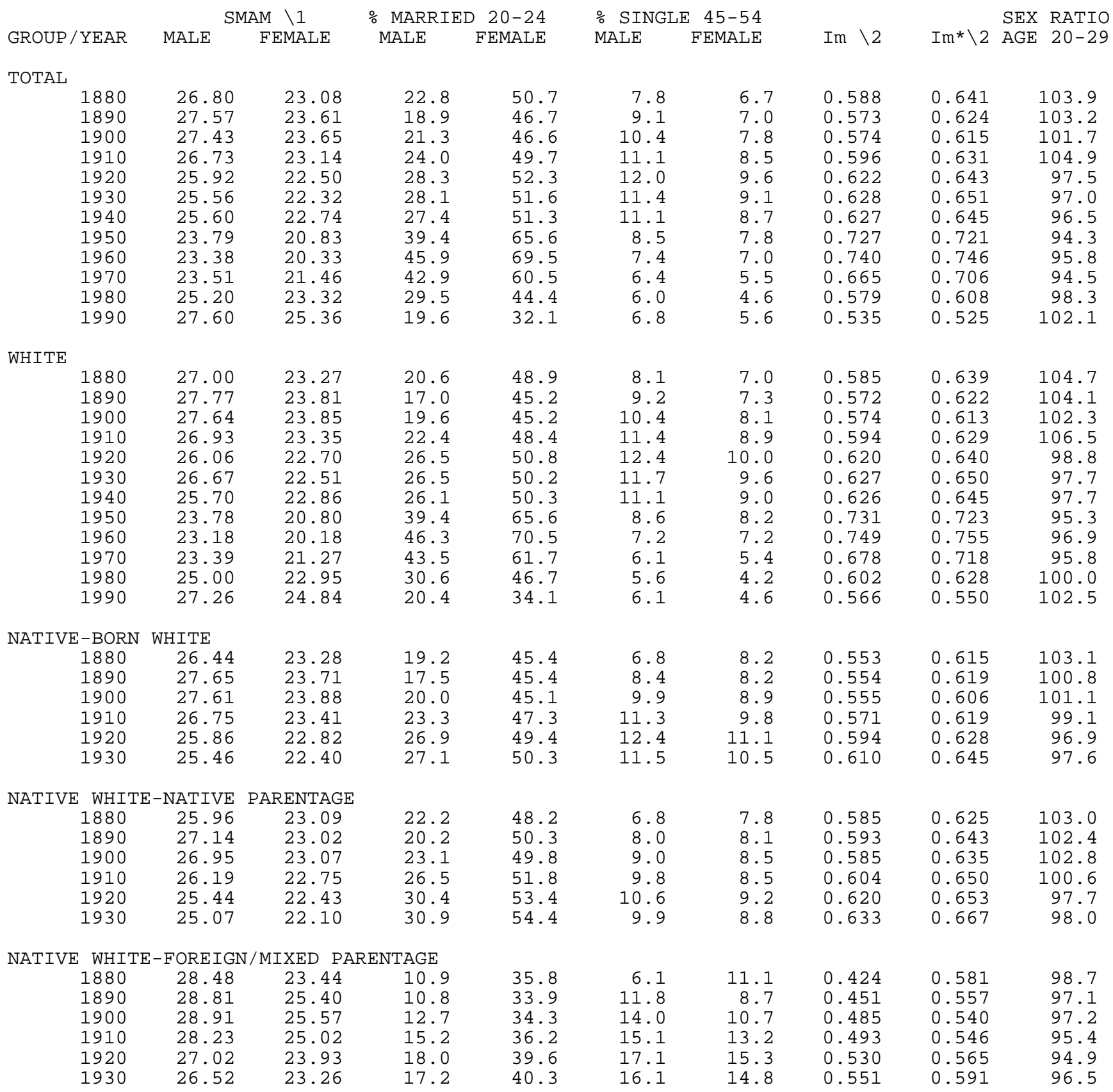


Table 13 (cont.)

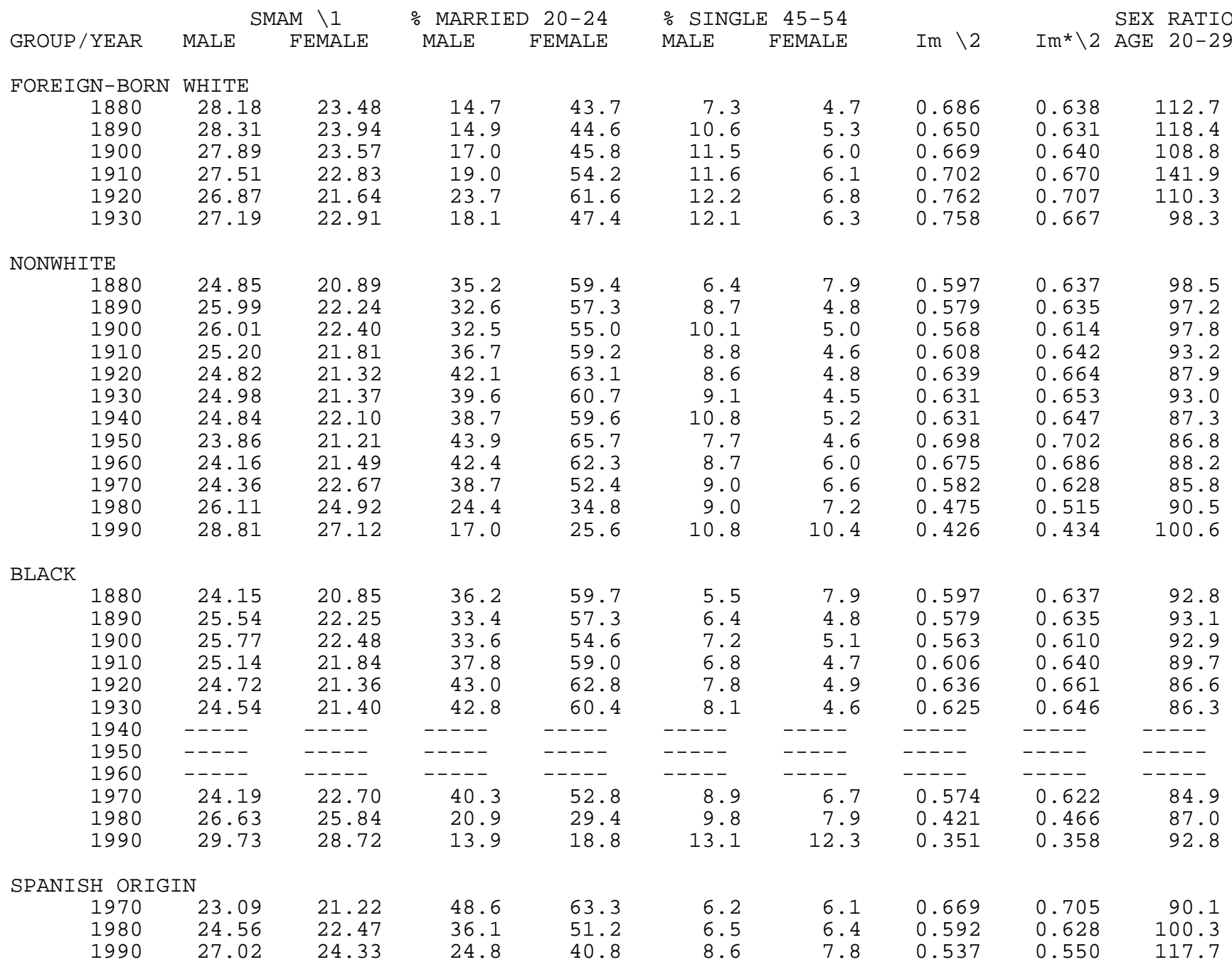

$\backslash 1$ SMAM is the singulate mean age at first marriage.

$\backslash 2 \mathrm{Im}$ is Coale's index of proportions married. Im* is the index of proportions married standardized for age structure.

Source: 1880: IPUMS, 1880 U.S. Census. 1890-1990: Various volumes, published U.S. Census. SMAM calculated by the procedure of Hajnal [1953]. Im and Im*: Coale and Watkins [1986], Appendix B. 

Table 14. Ratio of Nuptiality Measures to those for Whites. By Race \& Ethnicity. United States, 1880-1990.

\begin{tabular}{|c|c|c|c|c|c|c|c|c|c|}
\hline \multirow{2}{*}{ GROUP / YEAR } & \multicolumn{2}{|c|}{ SMAM } & \multicolumn{2}{|c|}{$\because$ MARRIED 20-24 } & \multicolumn{2}{|c|}{$\div$ SINGLE 45-54 } & \multirow[b]{2}{*}{$\operatorname{Im}$} & \multirow[b]{2}{*}{$\operatorname{Im} *$} & \multirow{2}{*}{$\begin{array}{ll}\text { SEX RATIO } \\
\text { AGE } & 20-29\end{array}$} \\
\hline & MALE & FEMALE & MALE & FEMALE & MALE & FEMALE & & & \\
\hline \multicolumn{10}{|l|}{ NONWHITE } \\
\hline 1880 & 0.920 & 0.898 & 1.709 & 1.215 & 0.790 & 1.129 & 1.021 & 0.997 & 0.941 \\
\hline 1890 & 0.936 & 0.934 & 1.918 & 1.268 & 0.946 & 0.658 & 1.012 & 1.021 & 0.934 \\
\hline 1900 & 0.941 & 0.939 & 1.658 & 1.217 & 0.971 & 0.617 & 0.990 & 1.002 & 0.956 \\
\hline 1910 & 0.936 & 0.934 & 1.638 & 1.223 & 0.772 & 0.517 & 1.024 & 1.021 & 0.875 \\
\hline 1920 & 0.952 & 0.939 & 1.589 & 1.242 & 0.694 & 0.480 & 1.031 & 1.038 & 0.890 \\
\hline 1930 & 0.937 & 0.949 & 1.494 & 1.209 & 0.778 & 0.469 & 1.006 & 1.005 & 0.952 \\
\hline 1940 & 0.967 & 0.967 & 1.483 & 1.185 & 0.973 & 0.578 & 1.008 & 1.003 & 0.894 \\
\hline 1950 & 1.003 & 1.020 & 1.114 & 1.002 & 0.895 & 0.561 & 0.955 & 0.971 & 0.911 \\
\hline 1960 & 1.042 & 1.065 & 0.916 & 0.884 & 1.208 & 0.833 & 0.901 & 0.909 & 0.910 \\
\hline 1970 & 1.041 & 1.066 & 0.890 & 0.849 & 1.475 & 1.222 & 0.858 & 0.875 & 0.896 \\
\hline 1980 & 1.044 & 1.086 & 0.797 & 0.745 & 1.607 & 1.714 & 0.789 & 0.820 & 0.905 \\
\hline 1990 & 1.057 & 1.092 & 0.833 & 0.751 & 1.770 & 2.261 & 0.753 & 0.789 & 0.981 \\
\hline \multicolumn{10}{|l|}{ BLACK } \\
\hline 1880 & 0.894 & 0.896 & 1.757 & 1.221 & 0.679 & 1.129 & 1.021 & 0.997 & 0.886 \\
\hline 1890 & 0.920 & 0.934 & 1.965 & 1.268 & 0.696 & 0.658 & 1.012 & 1.021 & 0.894 \\
\hline 1900 & 0.932 & 0.943 & 1.714 & 1.208 & 0.692 & 0.630 & 0.981 & 0.995 & 0.908 \\
\hline 1910 & 0.934 & 0.935 & 1.688 & 1.219 & 0.596 & 0.528 & 1.020 & 1.017 & 0.842 \\
\hline 1920 & 0.949 & 0.941 & 1.623 & 1.236 & 0.629 & 0.490 & 1.026 & 1.033 & 0.877 \\
\hline 1930 & 0.920 & 0.951 & 1.615 & 1.203 & 0.692 & 0.479 & 0.997 & 0.994 & 0.883 \\
\hline 1940 & ----- & ----- & ----- & ----- & ----- & ----- & ----- & ----- & ----- \\
\hline 1950 & ----- & ----- & ----- & ----- & ----- & ----- & ----- & ----- & ----- \\
\hline 1960 & ----- & ----- & ----- & ----- & ----- & ----- & ----- & ----- & ----- \\
\hline 1970 & 1.034 & 1.067 & 0.926 & 0.856 & 1.459 & 1.241 & 0.847 & 0.866 & 0.886 \\
\hline 1980 & 1.065 & 1.126 & 0.683 & 0.630 & 1.750 & 1.881 & 0.699 & 0.742 & 0.870 \\
\hline 1990 & 1.091 & 1.156 & 0.681 & 0.551 & 2.148 & 2.674 & 0.620 & 0.651 & 0.905 \\
\hline \multicolumn{10}{|c|}{ SPANISH ORIGIN } \\
\hline 1970 & 0.987 & 0.998 & 1.117 & 1.026 & 1.016 & 1.130 & 0.987 & 0.982 & 0.941 \\
\hline 1980 & 0.982 & 0.979 & 1.180 & 1.096 & 1.161 & 1.524 & 0.983 & 1.000 & 1.003 \\
\hline 1990 & 0.991 & 0.979 & 1.216 & 1.196 & 1.410 & 1.696 & 0.949 & 1.000 & 1.148 \\
\hline
\end{tabular}

Source: Table 13. 
Appendix Table A-1. Census Race Categories, 1790-1840.

Year

Race Category

1790

Free white males 16 years and upward, including heads of families under 16 years

Free white females, including heads of families

All other free persons

Slaves

1800-1810 Free white males, divided into 5 age groups

Free white females, divided into 5 age groups

All other free persons, except Indians not taxed

Slaves

1820

Free white males, divided into 6 age groups

Free white females, divided into 5 age groups

Slave males, divided into 4 age groups

Slave females, divided into 4 age groups

Free colored males, divided into 4 age groups

Free colored females, divided into 4 age groups

All other persons, except Indians not taxed

1830-1840 Free white males, divided into 13 age groups

Free white females, divided into 13 age groups

Slave males, divided into 6 age groups

Slave females, divided into 6 age groups

Free colored males, divided into 6 age groups

Free colored females, divided into 6 age groups

Source: Adapted from Anderson and Fienberg [1999\}, Table 8.1. Originally from Wright and Hunt [1900]. 
Appendix Table A-2. Census Race Categories, 1850-1990.(a)

\begin{tabular}{|c|c|c|c|}
\hline Year & & Census Race & Category \\
\hline $1850(\mathrm{~b})$ & & B & M \\
\hline $1850(\mathrm{~b})$ & & B & $\mathrm{M}($ Ind. $)(\mathrm{c})$ \\
\hline 1870 & $\mathrm{~W}$ & $\mathrm{~B}$ & $M, C, I$ \\
\hline 1880 & $\mathrm{~W}$ & B & $M, C, I$ \\
\hline 1890 & white & $\mathrm{black}$ & $\begin{array}{l}\text { mulatto, quadroon, octoroon, Chinese, } \\
\text { Japanese, Indian }\end{array}$ \\
\hline 1900 & $\mathrm{~W}$ & $\mathrm{~B}$ & $\mathrm{Ch}, \mathrm{Jp}, \mathrm{In}$ \\
\hline 1910 & $\mathrm{~W}$ & $\mathrm{~B}$ & $\mathrm{Mu}, \mathrm{Ch}, \mathrm{Jp}, \mathrm{In}$, Ot (+ write in) \\
\hline 1920 & $\mathrm{~W}$ & B & $\begin{array}{l}\text { Mu, In, Ch, Jp, Fil, Hin, Kor, } \\
\text { (Other races, spell out in full) }\end{array}$ \\
\hline 1930 & $\mathrm{~W}$ & Neg & $\begin{array}{l}\text { Mex, In, Ch, Jp, Fil, Hin, Kor, } \\
\text { (Other races, spell out in full) }\end{array}$ \\
\hline 1940 & $\mathrm{~W}$ & Neg & $\begin{array}{l}\text { In, Ch, Jp, Fil, Hin, Kor, } \\
\text { (Other races, spell out in full) }\end{array}$ \\
\hline 1950 & $\mathrm{~W}$ & Neg & Ind, Jap, Chi, Fil, (Other race--spell out) \\
\hline 1960 & White & Negro & $\begin{array}{l}\text { American Indian, Japanese, Chinese, Filipino, } \\
\text { Hawaiian, Part Hawaiian, Aleut, Eskimo, (etc) }\end{array}$ \\
\hline 1970 & White & $\begin{array}{l}\text { Negro or } \\
\text { Black }\end{array}$ & $\begin{array}{l}\text { Indian (Amer), Japanese, Chinese, Filipino, } \\
\text { Hawaiian, Korean, Other (print race) }\end{array}$ \\
\hline 1980 & White & $\begin{array}{l}\text { Negro or } \\
\text { Black }\end{array}$ & $\begin{array}{l}\text { Japanese, Chinese, Filipino, Korean, } \\
\text { Vietnamese, Indian (Amer), Asian Indian, } \\
\text { Hawaiian, Guamanian, Samoan, Eskimo, Aleut, } \\
\text { Other (specify) }\end{array}$ \\
\hline 1990 & White & $\begin{array}{l}\text { Negro or } \\
\text { Black }\end{array}$ & $\begin{array}{l}\text { Indian (Amer), Eskimo, Aleut, Chinese, } \\
\text { Filipino, Hawaiian, Korean, Vietnamese, } \\
\text { Japanese, Asian Indian, Samoan, Guamanian, } \\
\text { Other API, Other race }\end{array}$ \\
\hline
\end{tabular}

(a) The categories are given in the order in which whey appeared on the schedule or in the enumerator's instructions. The abbreviations are those that were to be used on the schedules. $\mathrm{W}=$ white; $\mathrm{B}=\mathrm{black} ; \mathrm{M}=$ Mulatto; Neg=Negro; I, In, Ind., or Indian (Amer)=Indian (Amerindian); $\mathrm{C}$, Ch, or Chi=Chinese; Jp or Jap=Japanese; Ot=other; Fil=Filipino; Hin=Hindu (South Asian Indian); Kor=Korean; Mex=Mexican; API= Asian or Pacific Islander.

(b) In 1850 and 1860, on the schedule for free persons, the instructions to the enumerators were "in all cases where the person is White leave the space blank in the column marked 'Color'." For the slave schedule, the listed categories were "B" and "M".

(c) Although a category for Amerindian people was not listed on the census form, the enumerator's instructions for 1860 were: "5. Indians - Indians not taxed were not to be enumerated. The families of Indians who have renounced tribal rule, and who under state or Territorial laws exercise the rights of citizens, are to be enumerated. In all such cases write "Ind." opposite their names, in column 6, under the heading "Color"...9. Color. Under heading 6, entitled "Color," in all cases where the person is white leave the space blank; in all cases where the person is black with admixture insert the letter "B"; if a mulatto, or of mixed blood, write "M"; if an Indian, write "Ind." It is very desirable to have these instructions carefully observed."

Source: Adapted from Anderson and Fienberg [1999\}, Table 8.2. Originally from Wright and Hunt [1900] and U.S. Bureau of the Census [1979, 1993]. 
Appendix Table A-3. Census Questions on Hispanic or Spanish Origin or Descent. 1970-1990.(a)

Year

Questions

1970

Is this person's origin or descent?

Mexican

Puerto Rican

Cuban

Central American

Other Spanish?(b)

1980

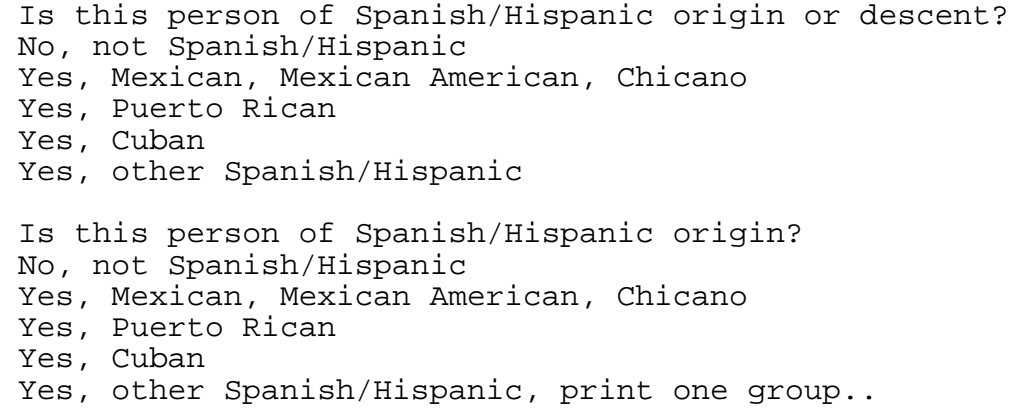

(a) The census asked a specific question on "Spanish origin or descent" in 1970 on the 5\% sample as a second part of a sample question on birthplace. In 1980, the question on "Spanish/Hispanic Origin or Descent" appeared on the short form (100\% sample). Before 1970, members of the Hispanic origin population could be identified by a combination of questions on palce of birth, place of birth of parents, and mother tongue. In the 1930 census only, the category "Mexican" was a separate category for answers to the question on "Color or Race." See Gratton and Gutmann [2000].

(b) This question appeared in the 1970 5\% sample long form.

Source: Adapted from Anderson and Fienberg [1999], Table 8.4. 
Figure 1

TFR in Relation to Whites

U.S. 1960-1998.

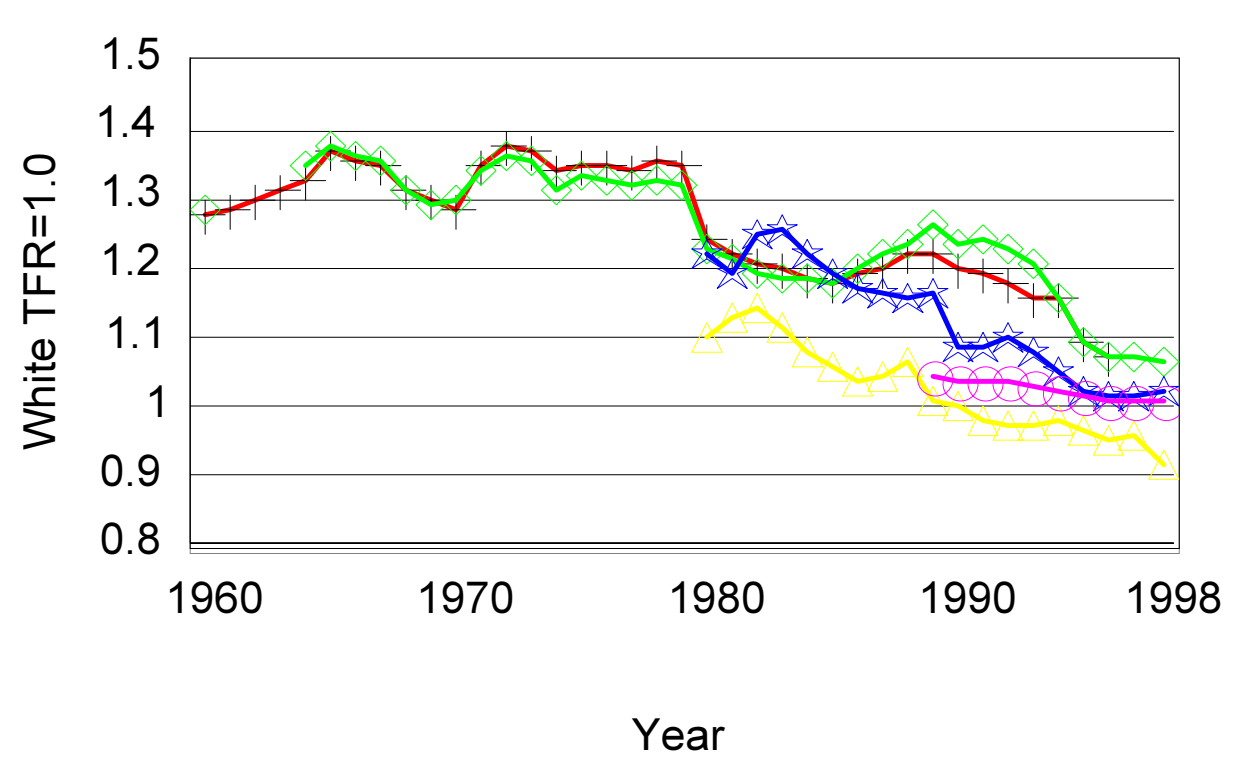

All Other

Black

Amerindian

Asian

Hispanic

Figure 2

Infant Mortality Rate in Relation to Whites

U.S. 1915-1998

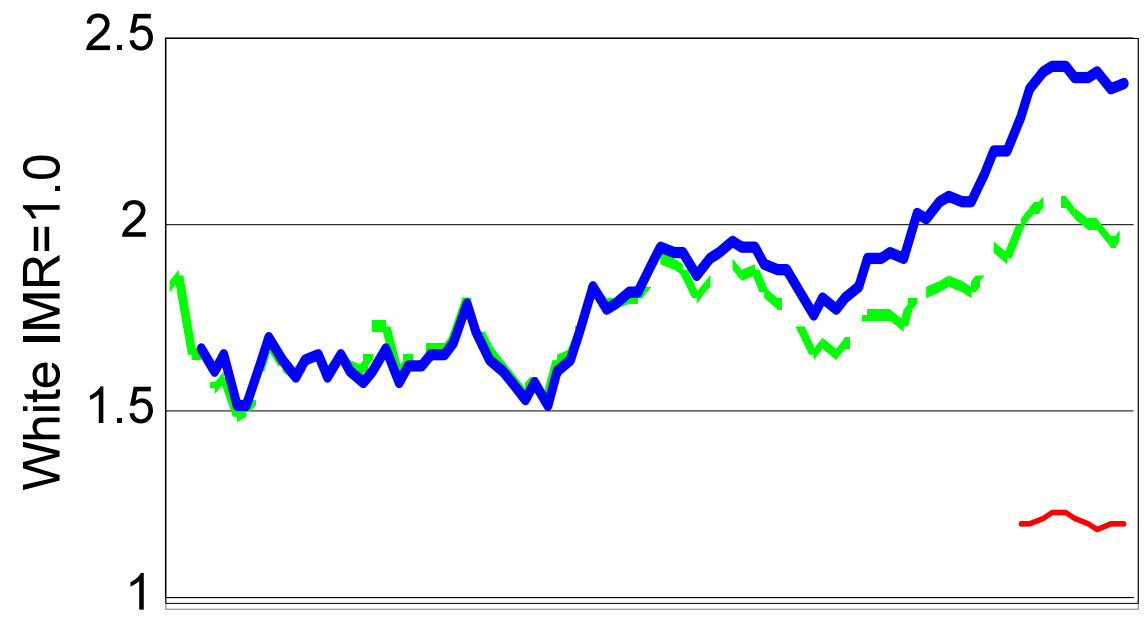

Nonwhite

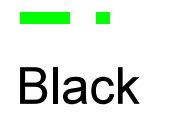

Hispanic

19201930194019501960197019801990

Year 
Figure 3

Singulate Mean Age at Marriage

By Race. U.S. 1880-1990.

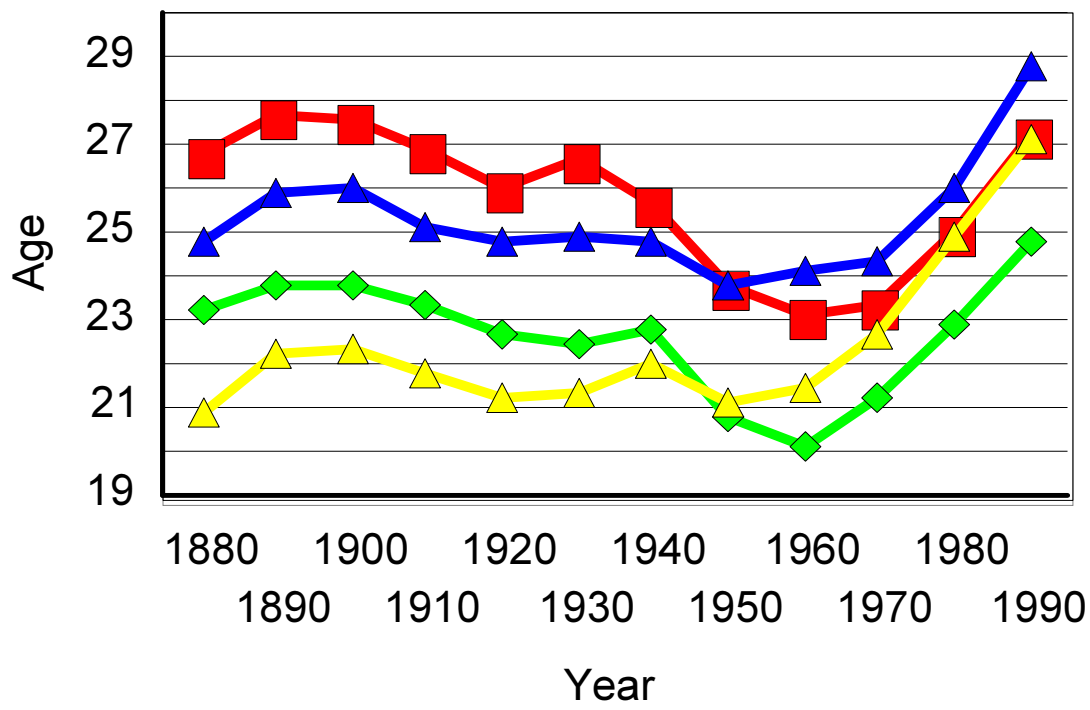

White Male

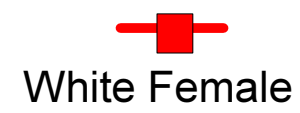

Nonwhite Male

Nonwhite female 